
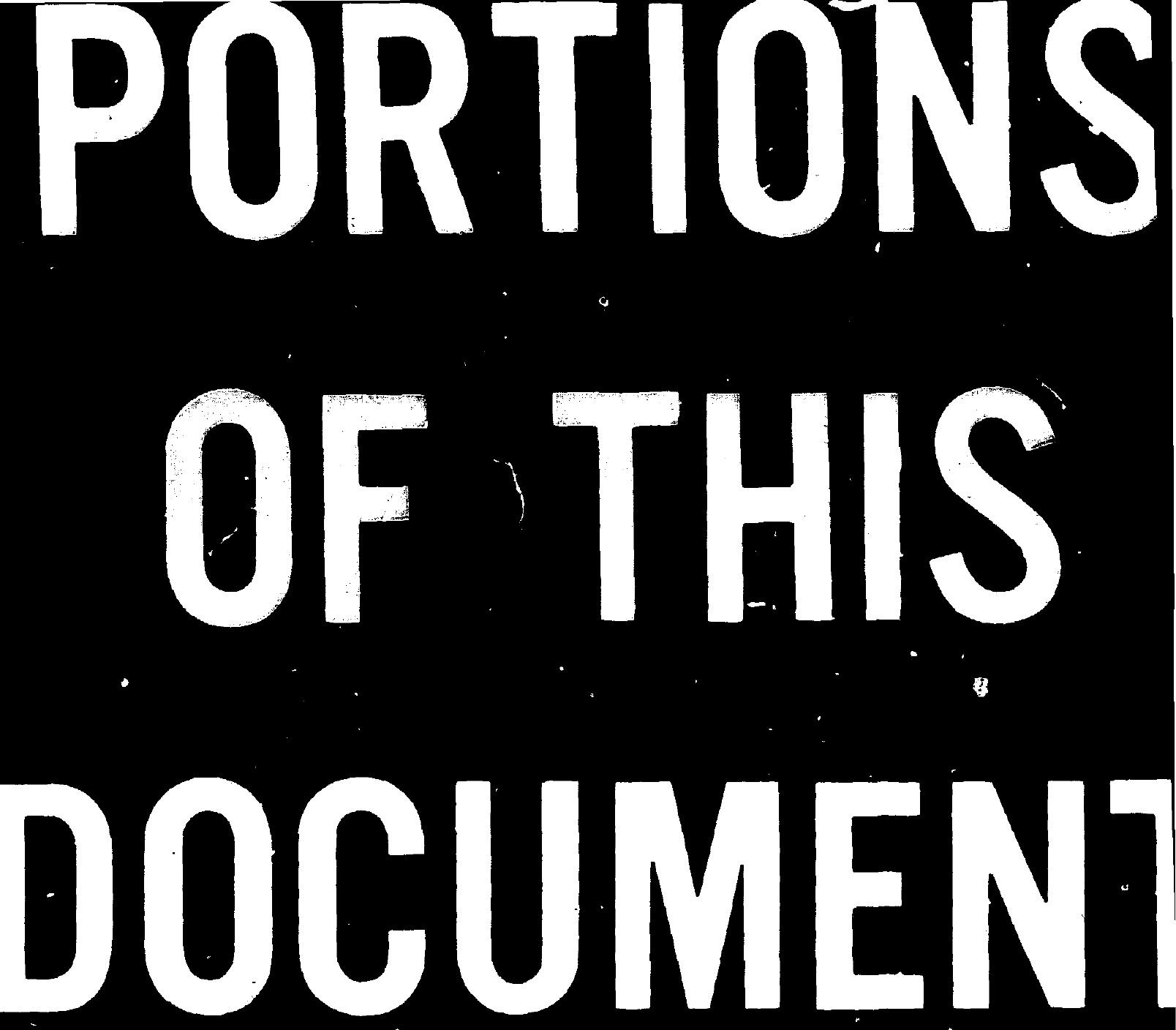

4

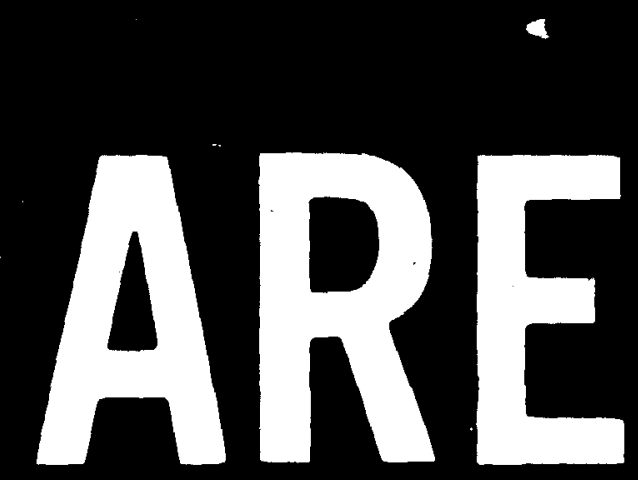

$\theta$

$+$
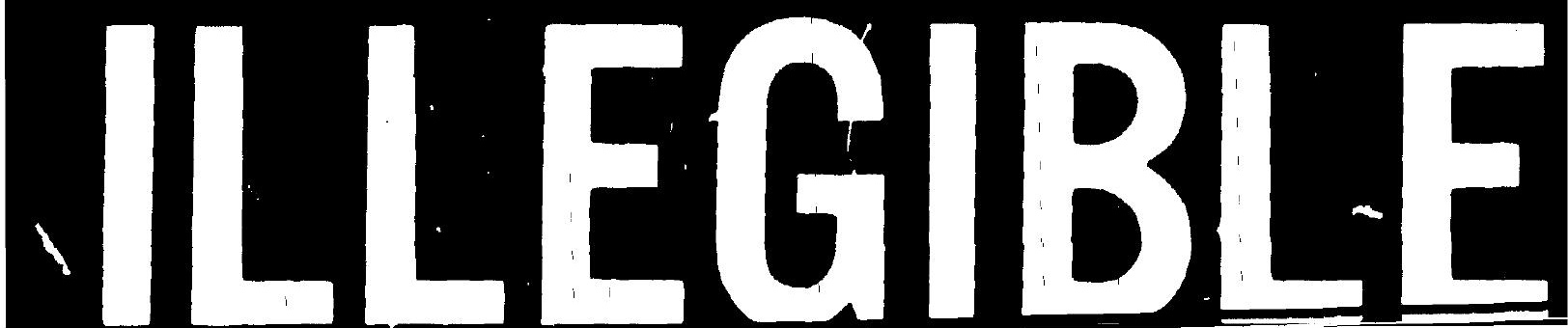


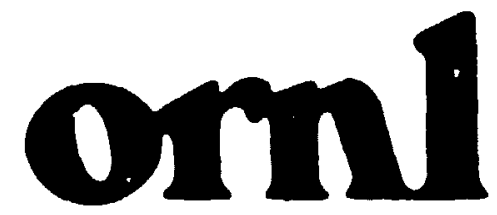

OAK

RIDGE

NATIONAL

LABORATORY

UNION

CARBIDE
MASTER

ORNL-5529

\section{Recommendations Concerning Models and Parameters Best Suited to Breeder Reactor Environmental Radiological Assessments}

Charles W. Miller

Charies F. Baes III

Donald E. Dunning. Jr.

Elizabeth L. Etnier

Kathy K. Kanak

David C. Kocher

Craig A. Little

Laura M. McDowell-Boyer

H. Robert Meyer

Elizabeth M. Rupp

Roberta W. Shor

OPERATEO BY

UNIOK CARBIOE CORPORATIOK

- FOR THE USITTEO STATES

DEPARTMENT OF ENERGY 


\title{
MASTER
}

ORNL-5529

Dist. Categories UC-11, UC-41, UC-79p

Contract No. W-7405-eng-26

Health and Safety Research Division

\author{
RECOMMENDATIONS CONCERNING MDDELS AND \\ PARAMETERS BEST SUITED TO BREEDER REACTOR \\ ENVIRONMENTAL RADIOLOGICAL ASSESSMENTS
}

$\begin{array}{ll}\text { Charles W. Miller } & \text { Davill C. Kocher } \\ \text { Charles F. Baes III } & \text { Craig A. Little } \\ \text { Fonald E. Dunning, Jr. } & \text { Laura M. McDowell-Royer } \\ \text { Elizabeth L. Etnier } & \text { H. Robert Meyer } \\ \text { Kathy K. Kanak } & \text { Elizabeth M. Rupp }\end{array}$

Roberta W. Shor

$1_{\text {Environmental Sciences Division }}$

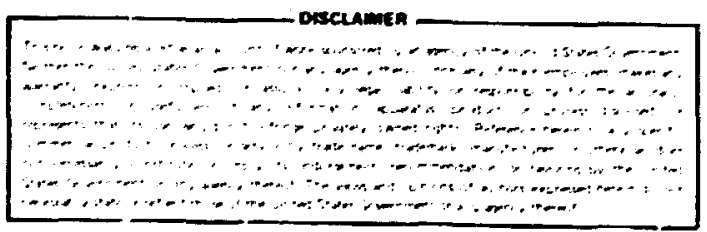

Date Published: May 1980

OAK RIDGE NATIONAL LABORATORY

Oak Ridge, Tennessee 37830

operated by

UNION CARBIDE CORPORATION

for thie

DEPARTMENT CF ENERG! 


\section{CONTENTS}

Page

List of Tables...................

Highl ights ........................ . . ix

1. Introduction (Charle's H. Miiler) ............. 1

2. Atmospheric Dispersion and Deposition

(Charles W. Miller)............... 7

2 Itmospheric Dispersion ............. 7

2.1.1 The Gausian plume model .......... 7

2.1.1.7 Dispersion parameters ........ 8

2.1.1.2 Release height .......... . 9

2.1.1.3 Radioactive decay .......... 12

2.1.2 Other atmospheric dispersion models ..... 12

2.2 Depnsition ........................ 13

2.2.1 Dry deposition ............. 13

2.2.2 Wet deposition .............. 14

2.2.3 Plume depletion ................ 15

2.2.4 Gravitational settling .......... 16

2.3 Duration of Release . . . . . . . . . . 17

3. Terrestriai Food Cha in Transport

(Laura M. McDoweil-Boyer and Charles F. Baes III) . . . . 23

3.1 Terrestrial Models ............... 23

3.1 .1 Concentrations in vegetation ........ 24

3.1 .2 Concentrations in milk .......... 26

3.1 .3 Concentrations in meat ........... 27 
Page

3.2 Terrestrial Transport Input Parameters . . . . . . . 28

3.2.1 Agricultural productivity by unit area,

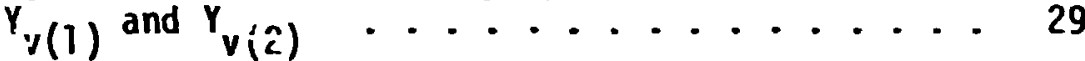

3.2.2 Interception fractions for above-ground plant portions, $R_{1}$ and $R_{2} \ldots . . . . .30$

3.2.3 Plant/soil bioaccumulation factor, $\mathrm{B}_{\mathrm{iv}}$.... 32

3.2.4 Milk transfer coefficient, $F_{m} \ldots . . . . .37$

3.2.: Meat trarsfer coefficient, $\mathrm{F}_{\mathrm{f}} \ldots \ldots 37$

3.2.6 Animal feed consumption $\left(Q_{F}\right)$, grazing patterns $\left(f_{p}, f_{s}\right)$, arid effective soi? surface density $(F)$........... 42

3.2.7 Time parameters $t_{e}, t_{b}, t_{h}, t_{f}$, and $t_{s} \ldots 42$

4. Sirface Water Transport (C. A. Litile).......... 55

4.! Model withuut Sorption .............. 55

4.2 Models with Sorption .............. 5?

5. Rọuatic Food Cha in Transport (Roberta W. Shor) ...... 63

5.1 The Basic Model ............... $6 \hat{\jmath}$

5.2 The Bioaccumulation Factor .......... 63

6. Gálut Dietary Intake and Inhalation Rates

iEl z za deth M. Rupp) .................. 71

?. Do:n Conversion Factors (H. Robert Meyer, Donald E. Dunning, Jr.. David C. Kocher, and

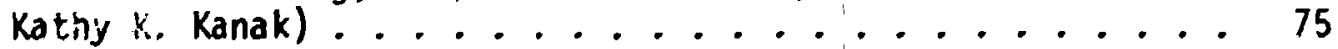

1.1 introduction ...................... 75

7.2 Ir:ternal Dose Conversion Factors . . . . . . . 75

73 Letei nal Dose Conversion Factors . . . . . . 8,6 
Page

3. Doses Due to Atmo:siner ic Releases of ${ }^{3} \mathrm{H}$ and ${ }^{14} \mathrm{C}$

8.1 Tritium $l_{i j}^{3} \ldots \ldots . \ldots 5$

8.1.1 Introduction ............. 95

8.1 .2 THe AIRDOS-EPA methodology for ${ }^{3} \mathrm{H} \ldots 96$

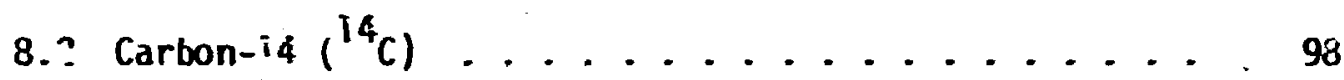

8.2.1 Introduction .................... 98

8.2.2 The AIROOS-EPA methodotogy for ${ }^{14} \mathrm{C} \ldots . . . .98$

Append ix A ...................... 103

Appendix B ............................... 117 


\section{LIST OF TABLFS}

Page

2.: Coefficients for specifying the Pasquill-Gifford system of dispersion parameters for six stability categcries... . 10

2.2 Coefficients for specifying two systems of disoersion parameters for six stability categories . . . . . .

3.1 Estimated values of above-grourd agricultural productivity and interception fractions for forage grasses and edible portions of vegetable r.rops ............

3.2 vaiues of $B_{\text {iv }(1)}\left[(\text { element })_{\text {forage }}:(\text { element })_{\text {soil }}\right]$ for

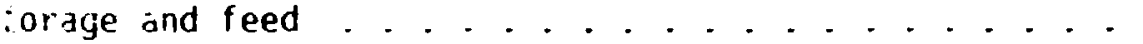

3.3 Values of $B_{\text {iv(2) }}$ [(élement) edibie tissue: (element) ${ }_{\text {soil }}$ ] for vegetables. fruits, and grains.......... 35

3 bilues of $F_{m}\left[(\text { sement })_{m i l k}\right.$ : elemental daily intake], dagliter ........................ 38

3.5 values of ${ }_{f}\left[(\text { element })_{\text {beef }}\right.$ : e emental daily intake $]$, $\mathrm{day} / \mathrm{kq}$

3.5 Values of $Q_{F}, f_{p}, f_{s}$, and $P$ used in terrestrial transport models at ORNL

3.7 Values of $t_{e}, t_{b}, t_{h}, t_{f}$, and $t_{s}$ used in terrestirial transport models at ORNL

5.: Results of a statistical analysis of $\mathrm{B}_{\mathrm{ip}}$ (liters/kg) for $\mathrm{Sr}$, I, anc. $C_{s}$ in freshwater finfish .......... 67

5.2 Values of $B_{i p}(1$ iters $/ \mathrm{kg})$ for various elements in aquatic foods

6. 1 Estimated values of inges:ion and inhalation rates f:3r ajuit individudis . . . . . . . . . . . .

1.1 Fifty-year dose commitments for inhalation or ingestion of certdin radionuclides (rem/ $\mu \mathrm{Ci}$ intake) ....... 
7.2 Externai dose conversion factors for immersion in cortaminated air (millirem/year per $\mu\left[i / \mathrm{cm}^{3}\right)$. . . . . $3 \vec{i}$

7.3 External dose conversion factors for exposure 0 contaminated ground surface (millirem/yes: per $\left.\mu / \mathrm{cm}^{3}\right) . .990$

8. 1 Dose conversion factors for ${ }^{14} \mathrm{C} \ldots \ldots 00$

A. I Principal pathways and nuclides for maximally exposed individuals from model facilities in the uran; cycle ...................... 107

A.2 Fraction of the 50-year dose camitment to the porulation within 50 miles of each fuel cycle facility from gaseous releases per year of operation of the facility.....

A. ? Fraction of the calcuiated total dose from one or mort radionuclides listed by aquatic pathway in several studies 
HIGHLIGHTS

F project is underway at Oak Ridge National Laboratory which has as its objective the identification of models available for environmental radiulogical assessments; evaluation of model structure, simplifyiilg assumptions and data bases; estimation of their uncertainties; and, if possible, the recommendation of the models and parameters which are best suited to particular assessment situations. When rzeds are identified, recommendations are also made for further environmer $I$ and bionitical research.

The purpose of this report is to present recommendations concerning the riodels and parameters best suited for assessing the impact of radionuclide releases to the environment by ureeder ractor facilities. These recommendations are based on the model and parameter evaluations performed during this project to date. Seven different areds are covered in separate sections of the report. These sections may be summarized as follows:

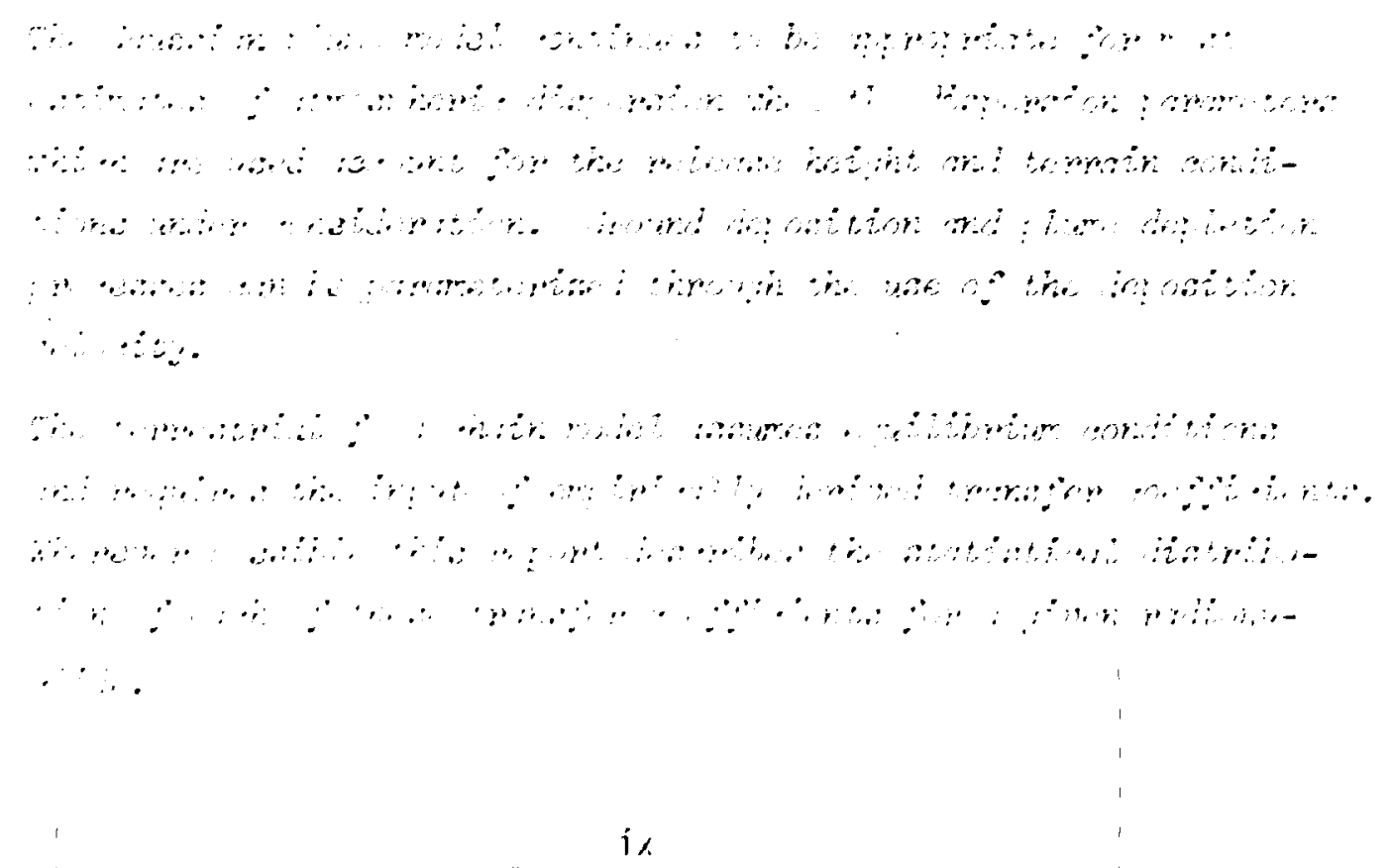




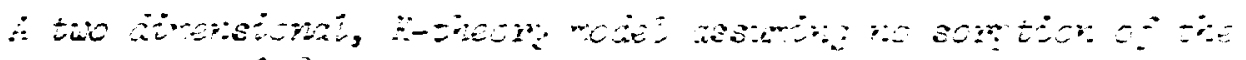

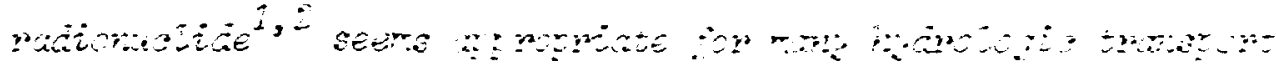
axousations.

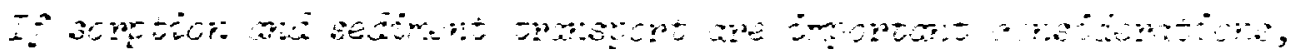

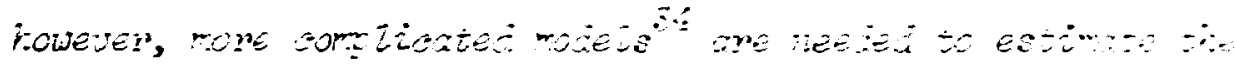

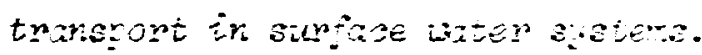

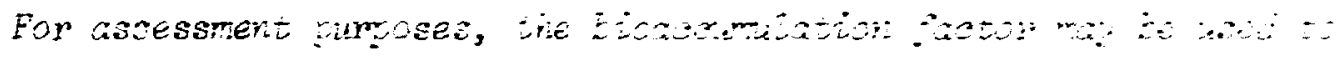

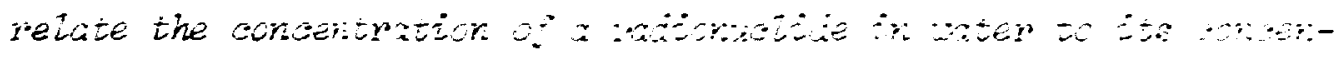

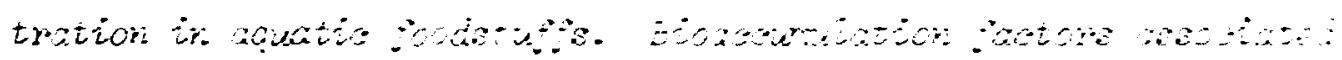

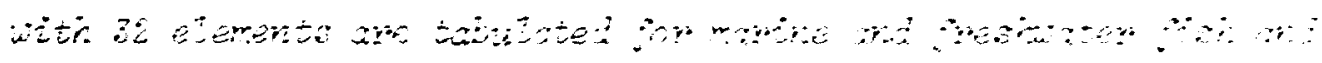
inverteinates.

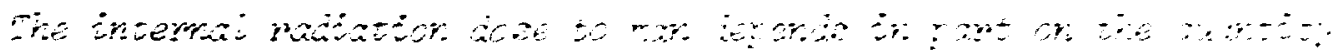
on:

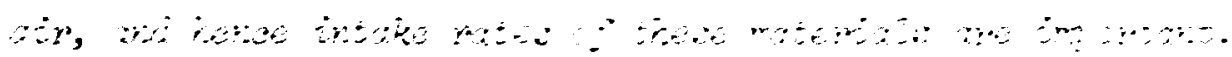

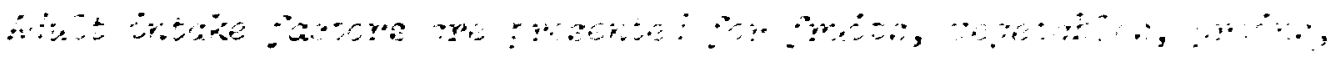

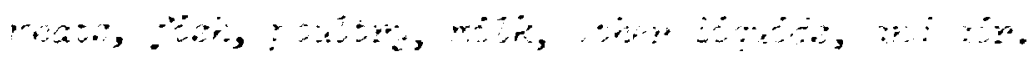

70 -

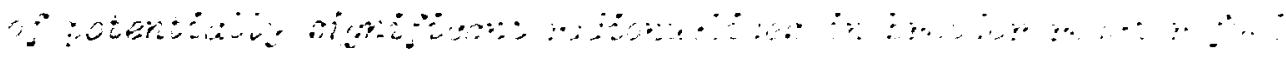

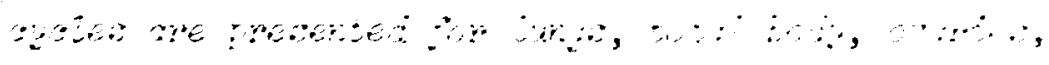

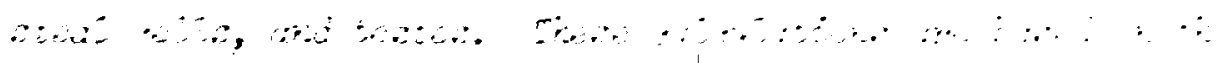

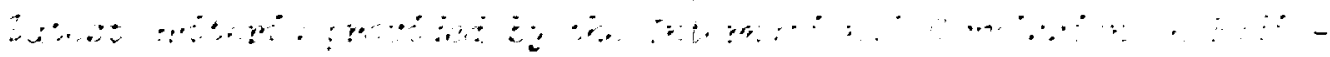

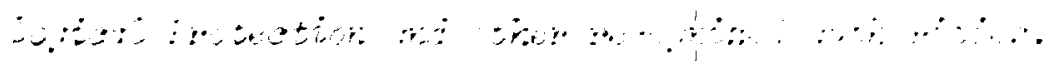

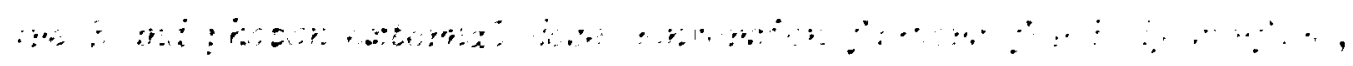

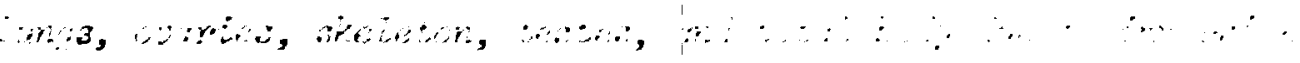

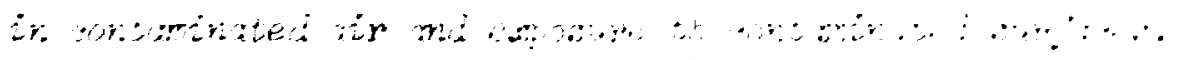

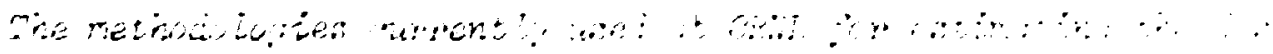

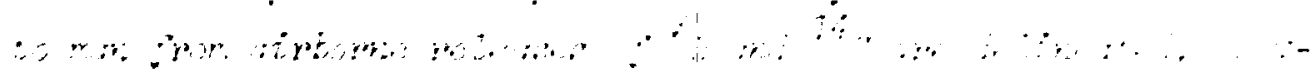

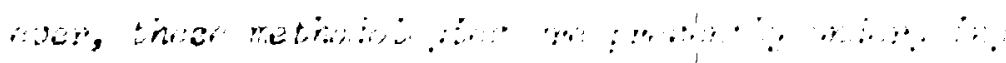

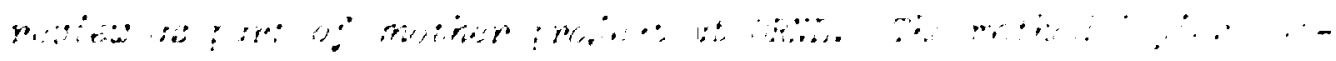

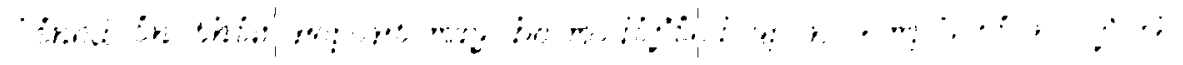
i............ 
biork on the model evaluation project is continuing at this time. is this work proceeds, modification of the recommer,dations presented in this report may be made to reflect the latest, indings of the project siaff. 
$x i i$

REFEREICES

1. Yotsukura, N. and W. W. Sayre. 1976. Transverse mixing in naturai channels. $\quad \because \because: \because \therefore \quad \therefore \therefore 12(4): 695-704$.

2. Yotsukura, N. and E. D. Cobb. 1972. Transverse Diffusion of

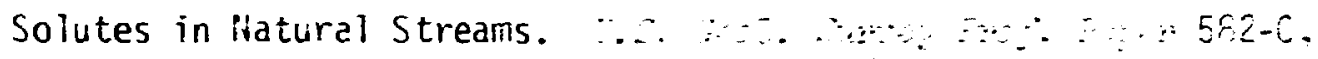
U.S. Government Printing Office.

3. Onishi, Y. and S. E. Wise. 1978. $\because \cdots, \cdots, \cdots$

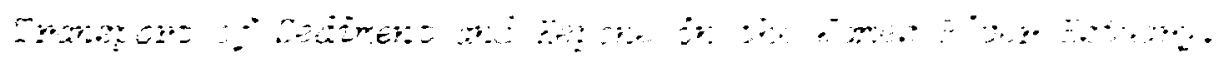

PNL -2731 .

4. Onishi, Y. 1977. ㅂ.

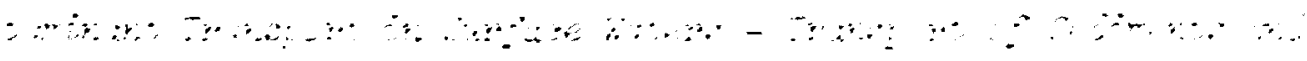

$$
\begin{aligned}
& \therefore \because \because \therefore \therefore=\therefore \quad \therefore \quad \because \quad \therefore \quad \therefore \quad \therefore \quad \text { BHWL-2227. }
\end{aligned}
$$




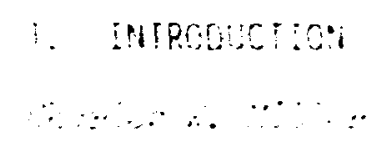

Gureatia a rumber of endironmenta! transport and dose caiculation

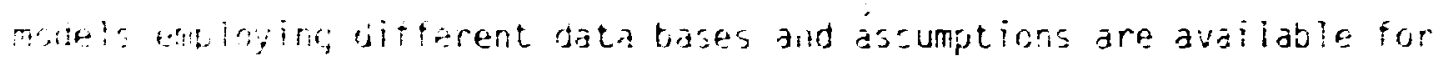
the asessmert of the radiolocical impact of routine and accidental disChro:s. The more cualuation project initiater at Oak Ridge Hational aburatoy (chple) has har as its oojectives identification of these mojels; evaluation of their structure, simplifying assumptions and data bases estimation of their uncer'ainties; and, if possible, recommendation of the rodels and parameters which are best suited ta particular wosesment situdions. Where nefds are identified, recomenterions are also mat. for fluther entironmental and biomedical research. The node: eraminod in this project to date include thrse developed ior the prodiction of atmospheric and hydrologic eransport and deposition, terrestria ind aquatic food-chain tsioaccumulatica, and internal and external dosimf: try.

The purpose of this particular report is to make recommenrations concerning models and paraneters for use in assessing the impact of breeder reactor radiodetive discharges to the envirument. These recommendations are based in the resultis of the model evaluations project to date. It shculd be noted, however, that this project is still underway, and these recc mendations may be adjusted as new information is analybed.

Ihis report contains summaries of the recommendations for each of the teronsort and dosimetry areas licted ahove. These smmaries reflect. the ark tof these individuals, who have conteributerd significantly to lhe 
project. Further details concerning the models and parameter values discussed may be found in the literature cited.

For assessment purposes, the simplest model which can be acceptably validated is deemed the most suitable for a given set of conditions.' The models consic ared in this report are based heaviiy on the recomnendations made by the model evaluation warkshop ${ }^{2}$ held as part of this project. Additicnal analyses of mndel uncertainty were also usad in selecting models for inclusion in this report. ${ }^{3}$

whenever possible, the input parameter valuas used in issessment $m r$ 'els should be based on site-specific information. This, however, is often not practical. In the absence of site-specific information, default values must he chosen for each model input parameter. Oftan, only a single value is ct.ssen for each parameter of interest. In reality, hcwever, each input parameter has a distribution of values associated with it. ?

During the course of the model evaluation project, data for a number of parameters have been exainined in an attempt to estimate "he distribution of values associated with a given parameter. However, it was ganerally found that few of the parameters analyzed have a dato base large enough to represent the lrue distribution. The assumption that the available data are representative of the true population of the parameter value of interest is also crucial as the data considered do not necessarily represent unbiased samples. 4

In this report, information on the estimated distribution associated with a given parameter value is presented wherever possible. If the data for a given parameter were lognormally distributed, the data were 
log-tı ansformed to produce a normal distribution, and estimates of the population mean is and stanaard deviation $s$ of the logarithms were determined. If the data were found to be normally distributed, the population mean $\bar{x}$ and standard deviation (S.D.) were estimated. If this information is available for a given parameter, the cumulative probability associated with any value chosen for the parameter can be determined. 1,4 The values of the various parameters to be used in an assessment calculation will depend on the cumulative probability desired in the final answer. Therefore, recommendation of a single value for any parameter for use in assessment calculations biases model predictions. Before choosing a parameter value an assessor should consult the cited literatưre to determine the potential effect of the linitations noted above on the final results.

Such an in-depth analysis has not yet been performed for all parameters and ali elements considered in this report. For these situations, the parameter values currently in use at ORNL have been entered and their origin cited. These values may change, however, as this project continces.

The dose conversion factors given in this report are based on model calculations rather than observations. It is not possible to validate these models subjects. These models, however, are based on the best animal and human data currently available.

A separate section in this report is devoted to the dosimetry of ${ }^{3} \mathrm{H}$ and ${ }^{14} \mathrm{C}$. These nuclides are often of special interest because of the importance of hydrogen and carbon in biological systems ans because they are important effluents of various fupl cycles. Methodolozies for assessing the dose to man from these nuclides are currently being evaluated 
by another project at ORNL. This report presents the methodology currently used for assessment purposes at ORNL. This methodology may be modified, hovever, as the evaluation continues.

As mentioned previously, work on this project is continuing. Current efforts are focusea in three major areas:

1. comparison of predictions from various environmenta? trarsport models with measured field wata to estimate che uncertainty in model output;

2. continued determination of distributions associated with model input pärameter values;

3. develofment of recomnendations for needed environmental aı:d biomedical research

As this work continues it may result in nodification of the information contained in this report. 


\section{REFERENCFS}

1. Shaeffer, D. L. 1979. A Model Evaluation Methodology Applicable to Environomental Assessment Models. ORNL-5507.

2. Hoffrian, F. D., D. L. Shaeffer, C. H. Miller and C. T. Garten, Jr. 1978. Proceedings of a Workshop on the Evaluation of Models used for tive Environmental Assessment of Pudionuclide Releases. Gatlinburg, Tennessee, September 6-9, 1977. CoNF-770901.

3. Little, C. A., and C. H. Miller. 1979. The Uncertainty Associated with Selected Environmental Tronsport Models. ORNL-5528.

4. Hoffman, F. O., D. L. Shaeffer, C. F. Baes III, C. A. Little, C. W. Miller, D. E. Dunning, Jr., E. M. Rupp, and R. W. Shor. 1979. An evaluation of uncertainties in radioeco, ogical models. IN Proseedings of the German-Swiss Fxchverband fur Strahlenechutz. Norderney, Federa! Republic of Germany, October 2-6, 1978. 


\section{ATMOSPHERIC DISPE!SION AND DEPOSITION}

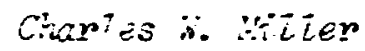

One of the principal ways in which radionuclides from breeder reactor facilities reach the environment is through discharges to the atmosphere. These discharges result in doses to man as a result of:

1. exposure to the contaminated air; and

2. exposure to surfaces and ingestion of foodstuffs contaminated by radionuclides removed from the plume by deposition processes.

\subsection{Atmospheric Dispersion}

Atmospheric dispersion calculations provide estimates of air concentration resulting from atmospheric discharges of radionuclides. These air concentrations are then used to calculate doses to man.

\subsubsection{The Gaussian plume model}

The Gaussian plume model ${ }^{1}$ is the most widely used method of estimating downwind air concentrations of radionuclides released to the atmosphere. ${ }^{2,3}$ It is also the liost often verified atmospheric dispersion model. 4 For a continuous point source and invariant meteorology, this model is given by

$$
x=\frac{Q}{\pi u \sigma_{y} \sigma} \exp \left[-1 / 2\left(\frac{H}{\sigma_{z}}\right)^{2}-1 / 2\left(\frac{\gamma}{\sigma_{y}}\right)^{2}\right],
$$

where

$$
\begin{aligned}
& x=\text { ground-level air concentration }\left(\mathrm{Ci} / \mathrm{m}^{3}\right), \\
& Q=\text { release rate }(\mathrm{C} i / \mathrm{sec}), \\
& H=\text { height of release }(\mathrm{m}),
\end{aligned}
$$


$u=$ mean wind speed over the height of the mixing Idyer $(\boldsymbol{m} / \mathrm{sec})$, $\sigma_{y}, \sigma_{z}=$ standard deviation of a Gaussian distribution in the cross wind $y$ and vertical $z$ directions, respectively (m).

For estimating the impact of routine (i.e., continuous) radionuclide releases, the average ground-level-cencentration in air over a sector $22.5^{\circ}$ wide is often used. It is giver. by

$$
x=\frac{2.032 Q}{x \bar{u} \sigma_{z}} \exp \left\{-1 / 2\left(\frac{H}{\sigma_{z}}\right)^{2}\right\}
$$

where

$x=$ the dowmind distance of interest, $m$;

$\bar{u}=$ average wind speed during time period of interest.

The Gaussian plume has a number of theoretical limitations. 5

However, when properly used it has been found to be a very practical tool for dispersion modeling. It is

1. mathewatically simple and flexible,

2. in accord with wuch, but not $a^{\prime \prime}$, diffusion theory, and

3. a reliable franework for the correlation of both field studies and mathematical and physical modeling studies of atmospheric diffusion. 5

2.1.1.1 Dispersion parameters. It has been found that the dispersion parameters, $s_{y}$ and $s_{z}$, need to be carefully specified when using the Gaussian plume nodel.6,7 A number of empirically determined graphs of $s_{y}$ and $s_{z}$ as a function of dowmind distance and atmospheric stability have been proposed. ${ }^{8}$ Geiß et ar. ${ }^{9}$ have published a useful set of comparisons between some of these sets of graphs. 
Whene er possitle, site-specific reasurements should be used to specify $\sigma_{y}$ and $\sigma_{z^{-}} 10$ when sets of standard curves are used instead, at least tws sucli sets should be used, one for surface releases and one for elevied relea ses. The Pasquill-Gifford curves' adjusted for averaging time ard s!!-face roughness have been suggested for use with the tormer $10,1 !$ iTat-ie 2.1). For elevated releases, the curves suggested by feib et a:. or hose measured at Brookhaven National Laboratory 12 have ieen rccumminded 10,11 (Table 2.2).

As noteri azove and in Tables 2.1 and 2.2, $\sigma_{y}$ and $\sigma_{z}$ depend on atmospheric stability. A number of different methods for classifying stability have been proposed, but these methods often give significantly difiereit resnlts when applied to the same meteorological data set. $13, ? 4$ Until encig! data beccme available to select the best method of classifying stability, the user of the Gaussian plume model must exercise care in choosing stabilities. The selection of a stability category alone can result in a factor of four difiference between the lowest and highest annual average air concentratioir estimated from a given set of $\sigma_{y}$ and $\sigma_{z}$ curves. 13,14

2.1.1.2 Release height. The effective release height, $H$, is also a critical parameter in Eqs. (1) and (2),6,7 The value of $H$ depends on more than just the physical height of the stack, $h: 15$

$$
H=h+h_{p r}-h_{t}-C \text {, }
$$

where

$$
\begin{aligned}
& h_{p r}=\text { rise of plume above the release point due to buoyancy and } \\
& \text { momentum. }
\end{aligned}
$$


Table 2.1. Coefficients for specifying the Pasquill-Gifford systeri of dispersion parameters for six stability categories 9

\begin{tabular}{|c|c|c|c|c|c|c|}
\hline \multirow[b]{2}{*}{ Coefficient } & \multicolumn{6}{|c|}{ Atmospheric stabili ity category } \\
\hline & A & B & C & $\mathbf{D}$ & $\mathbf{E}$ & $\mathbf{F}$ \\
\hline${ }^{a} 1$ & $-G .023$ & -0.015 & -0.012 & -0.0059 & -0.0059 & -0.0029 \\
\hline${ }^{\circ} 2$ & 0.35 & 0.25 & 0.18 & 0.11 & 0.0881 & $0.054 i$ \\
\hline$b_{1}$ & 0.83 & -0.99 & -1.19 & -1.35 & -2.88 & -3.80 \\
\hline$b_{2}$ & -0.15 & 0.82 & 0.85 & 0.79 & 1.26 & 1.42 \\
\hline $\mathrm{b}_{3}$ & 0.15 & 0.017 & 0.0045 & 0.0022 & -0.0421 & -0.0551 \\
\hline
\end{tabular}




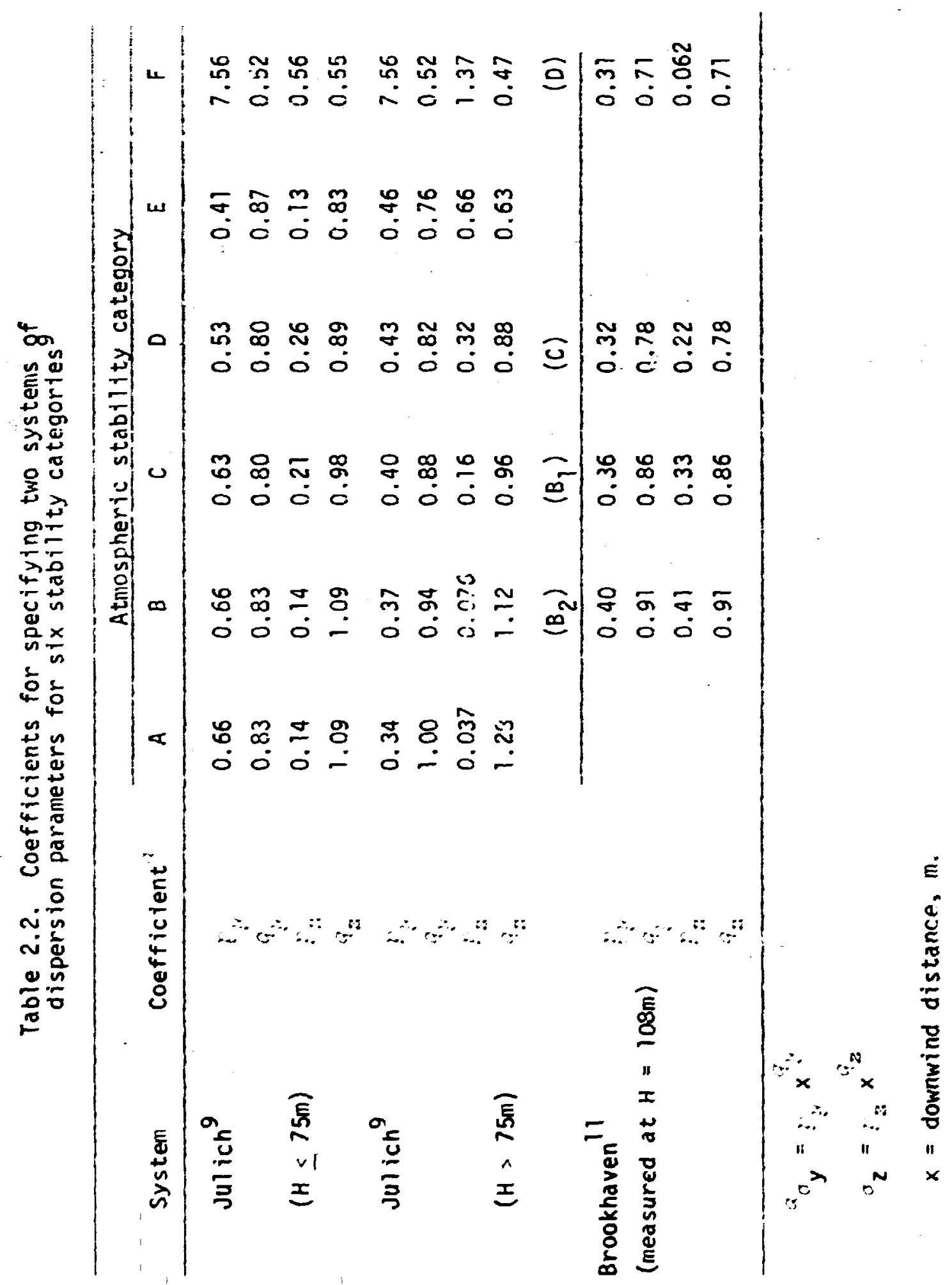


$h_{t}=$ maximum terrain height (above the stack base) between the release point and the point for which the calculation is being made $\left(h_{t} \geq 0\right)$,

$C=$ dowmwash correction factor.

Values of $h_{p r}$ are usually calculated through the use of models such as those suggested by Briggs. 16 Models have also been proposed for calculating $C .{ }^{15}$ The need to include estimates of $h_{p r}, h_{t}$, and $c$ in estimates of $\mathrm{H}$ for a given radiological assessment will depend on the particular facility under consideration and its location.

2.1.1.3 Radioactive decay. The Gaussian model, as expressed by Eqs. (2.1) and (2.2), assunes no change in the species of material released as it is being transported downwind. This, of course, is not the case when the released material is radioactive. As a result, air concentrations of radionuclides calculated using the model should be corrected to account for decay of the material during transit and subsequent buildup of daughter products. ${ }^{i 7}$.

\subsubsection{0ther atmospheric dispersion models}

There are a number of situations commonly encountered in radiological assessments for which the Gaussian plume model may not apply or may be difficult to parameterize. These include instances involving complex terrain, long range transport, time-varying meteorology, and variable release rates. As a result, a large number of more camplex, seemingly more realistic, dispersion models have been developed. However, to run properly, these models of ten require a much more extensfve infist data base than the Gaussian model, a computer with large storage capacity, and a long computer running time for each simulation desired. These 
conditions can severely limit the practicality of using a more complex model in assessment activites. The trajectory model ${ }^{18}$ is gaining accepzance as a tool for estimating dispersion on a continental scale. ${ }^{19}$ In general, however, more field data are needed to specify clearly when a given complex mudel should supplement the Gaussian plume model in radiological assessinents.

\subsection{Deposition}

Particulates and reactive gases may deposit on the surface of the earth through the processes of dry and wet deposition. These processes affect doses to man from atmospheric releases of radionuclides in two ways:

1. deposited material serves as a source of surface and/or food chain contamination;

2. deposition results in a reduction in the amount of material transported downwind in air through plume depletion.

\section{2.?.1 Dry deposition}

Dry deposition is the process by which particles and reactive gases deposit on various surfaces (soil. grass, leaves, etc.) via impingement, electrostatic interactions, chemical reactions, and other processes. The rate of deposition $\mathrm{d}\left(\mathrm{Ci} / \mathrm{m}^{2} \cdot \mathrm{sec}\right)$ is given by ${ }^{20}$

$$
d=x v_{d},
$$

where

$$
\begin{aligned}
& x=\text { ground-level air concentration }\left(\mathrm{Ci} / \mathrm{m}^{3}\right), \\
& v_{d}=\text { deposition velocity }(\mathrm{m} / \mathrm{sec}) .
\end{aligned}
$$


The depesition velocity defired in Eq. (2.4) is a transfer factor relating an air concentration to a surface deposition rate. Field measurements of $v_{d}$, however, are generally based on measured concentrations in vegetation cut at a specific height above ground. 21,22 Thus, an estimate of $v_{d}$ appropriate for the total deposit on a unit area basis is derived from a $v_{d}$ specific for deposition onto vegetation by $^{17}$

$$
v_{d}(\operatorname{tota} 1)=v_{d}(\text { vegetation }) / R
$$

where

$R=$ fraction of the total material being deposited which is intercepted by the surface of interest.

Values of $v_{d}$ (vegetation) for forage grasses have been determined: ${ }^{23}$

1. $0.02 \mathrm{~m} / \mathrm{sec}$ for reactive gases (molecular iodine),

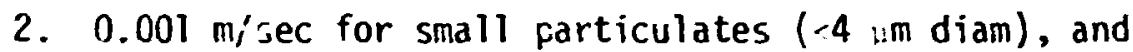

3. $0.0001 \mathrm{~m} / \mathrm{sec}$ for relatively unreactive gases $\left(\mathrm{C}_{3} \mathrm{I}\right)$.

Using a mean forage grass irterception fraction value of $R=0.57$ (Sect.

3) results in the following values of $v_{d}$ (total):

1. $0.035 \mathrm{~m} / \mathrm{sec}$ for reactive gases,

2. $0.0018 \mathrm{~m} / \mathrm{sec}$ for small particulates, and

3. $0.00018 \mathrm{~m} / \mathrm{sec}$ for relatively unreactive yases.

If the plume traverses surfaces other than grasslands, other values of $v_{d}$ (total) should be considered if they are available. 22

\subsubsection{Wet deposition}

Wet deposition is the process by which particles or gases are scavenged from a plume by rain or snow and deposited on ground surfaces. The rate of deposition on ground surfaces from these processes, 10 , is often estimated by 24 


$$
w=\therefore \text { va } \mathrm{L},
$$

where

: fraction of materiযl scavenged fram a vertical column of air per unit time $\left(\mathrm{sec}^{-1}\right)$,

$$
x_{v a}=\text { average concentration in vertical column }\left(\mathrm{Ci} / \mathrm{m}^{3}\right) \text {, }
$$

$L=$ height of vertical column (n).

The value chosen for $L$ is often the deptr: of the tropospheric mixing layer. 24

It has also been suggested that the wet deposition rate for longterm average situations can be calculated by using Eq. (2.4) and a wet deposition velocity $v_{w}$ which is given by ${ }^{11}$

$$
v_{v:}=\frac{k_{0} p}{z_{0}}=w_{r} p,
$$

where

$k_{0}=$ surface level concentration in the precipitation $\left(\mathrm{C} / \mathrm{m}^{3}\right)$,

$y_{0}=$ surface level air concentration $\left(\mathrm{Ci} / \mathrm{m}^{3}\right)$,

$p=$ amount of precipitation per unit time (m/year),

$w_{r}=\frac{k_{0}}{v_{0}}=$ washout ratio.

A comparison of results from these two methods (Eqs. 2.6 and 2.7) using annual average meteorological data for Cak Ridge, Tennessee, indicates that beyond $1 \mathrm{~km}$ downwind from the source there is iittle difference between them. ${ }^{25}$ For considering wet deposition from a single event, however, Eq. (2.6) is the more appropriate method to use. Ii

\section{2 .3 Plume depletion}

Deposition processes deplete the airborne plume as it travels oownwind. The most common method of accounting for this removat is 
reducing the release rate of the material. In the case of the Gaussian model [Eq. (2.I)] this new release rate $Q^{\prime}$ is given for dry deposition by

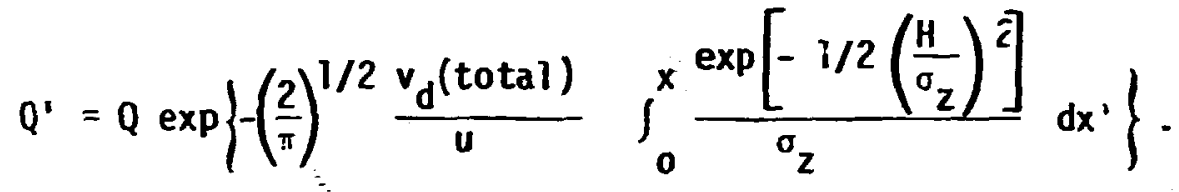

A number of other methods of accounting for plume depletion have been proposed, but until validation data become available for determining waich one is really best, the continued use of $\mathrm{Eq}$. (2.7) seems reasonab?e. 25

If wet deposition is estimated using Eq. (2.6) and a scavenging coefficient : the reduced release rate is given by ${ }^{24}$

$$
Q^{\prime}=Q \exp \left(-\Phi^{\prime} t\right),
$$

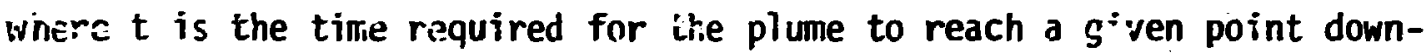
wind, and is averaged over the entire time period of interest, including periocis without precipitation. If Eq. (2.7) is used to estimate wet deposition, however, Eq. (2.8) may be used to estimate plume depletion by substituting $v_{w}$ for $v_{d}$.

\subsubsection{Gravitational sattling}

Frivations (2.4) and (2.8) apply when the gases or particulates in the plume are small enough not to be significantly affected by gravity as they travel downivind. If the plume contains larger particles, r. swever, the gravitational settling may be approximated by tilting the plume dow nward. ihis is done by replacing the effective stack height $H$ by 24

$$
H-\frac{v_{g} x}{u},
$$

where 


$$
\begin{aligned}
& v_{g}=\text { gravitational fall velocity }(\mathrm{m} / \mathrm{sec}) \\
& x=\text { downwind distance of interest }(\mathrm{m})
\end{aligned}
$$

It must be specified that $H-\frac{v_{g} x}{u} \geq 0$.

\subsection{Duration of Release}

The point-source Gaussian plume model, Eq. (2.1) and (2.2) with the modifications discussed above, attempts to define a mean concentration discussed above, attempts to define a mean concentration field relative to a fixed location over some relatively iong period of time. 5 The averaging time of the model is that of the diffusion data upon which dispersion parameters are based. Not all sets of dispersion parameters have the same release or sampling time. For example, the PasquillGifford curves are based on a sampling duration of 3 minutes ${ }^{10}$ while the Julich parameters are based on releases of generally ! hr duration.

often times one is interested in calculating concentrations for averaging times other than the one applicable for the dispersion parameters being used. It has been suggested 5,10 that this can be accomplished by modifying $\sigma_{y}$ according to the following relationship:

$$
\frac{\sigma_{y A}}{\sigma_{y B}}=\left(\frac{t_{A}}{t_{B}}\right)^{q}
$$

where

$$
\begin{aligned}
\sigma_{y A}= & \text { horizontal dispersion parameter average over some time period } \\
& \text { of interest, } t_{A} \text {, and } \\
\sigma_{y B}= & \text { original value of the horizontal dispersion parameter based } \\
& \text { on diffusion data averaged over some time period } t_{B} .
\end{aligned}
$$


Reasonable values for $q$ have been found to be in the ranye of $0.25-0.3$ for $1 \mathrm{hr}-\mathrm{t}_{\mathrm{A}}-100 \mathrm{hr}$ ans approximately equals 0.2 for 3 rin $-t_{A}-1 \mathrm{hr}^{5,10}$ a similar relationship could be applied to ${ }_{2}$, but such variations ir ; should not extend beyond a few kilometers downvind of the release point.

For calculating average concentrations over long time periods, such as a season or a year, Eq. (2.2) is generally used with a weighting for the fraction of the time that the wind blows toward the point of interest. 5 Joint frequency distributions of wind direction, wind speed, and atmospheric stability can be constructed for many locations from climatological records.

The methods discussed in this chaper must be further mojified to culculate dispersion from sudden, exriusive, or very short terr: i.e., $t_{\mathrm{B}} \cdot 3 \mathrm{~min}$ ) releases of material to the atmosphers. In general, the values of $y$ and $z$ used for such releases are considered to be different than the values presented above for longer time releases. 1 Also, dispersion in the downwind direction must be taken into consideration for very short term releases. However, virtually nothing is known about the downwind dispersion parameter, $x^{-5}$ Accidental releases from breeder reactor facilities have generally been considered to be of long enough duration for the methods considered in this section to be applied. 26 


\section{REFEREFICES}

1. Gifford, F. A., Jr. 1958. An uutline of theories of diffusion in the lower atmosphere. Chapter 3. If siade, 0. (ed.), ......

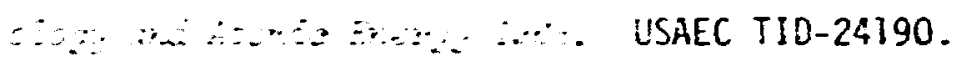

2. Hoffman, F. 0., C. W. Miller, D. L. Snaeffer, C. T. Garten, Jr., R. W. Shor, and J. T. Ensminger. 1977. $\therefore$ :

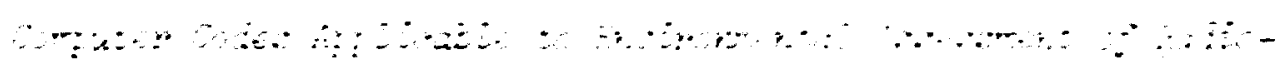
$\therefore \therefore \quad \therefore \quad$ ORNI/TM-5830.

3. Hoffman, F. 0., C. K. Miller, D. L. Snaeffer, and C. T. Garten, Jr. 19it. A compitation of computer codes for the assessment of radioruclides released to the environment. $\therefore \ldots \therefore \therefore 18(3): 343-54$.

4. Little, C. 4., and C. H. Milier. 1979.

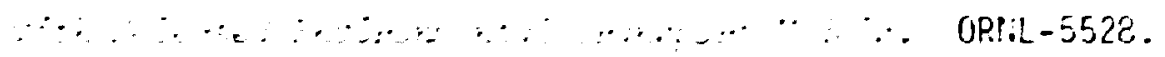

5. Gifford, F. F., Jr. 1975. Atrospheric dispersion models for environsental pollution applications. Chapter 2. IN Haugen, D. A. (coord.), $\because \cdots, \cdots, \cdots, \cdots, \cdots, \cdots, \cdots, \cdots, \cdots, \cdots$

$\therefore \therefore$ American Meteorological Society, Boston.

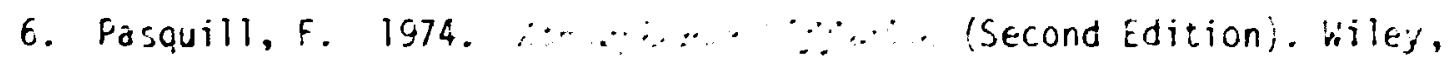
New rork.

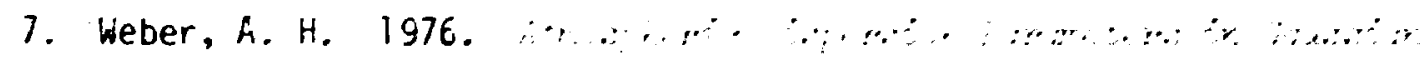

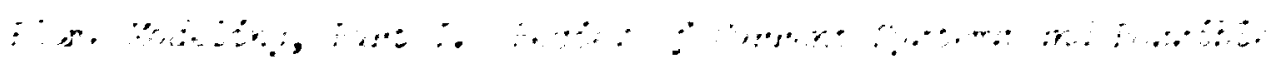
$\therefore \therefore \cdots \cdots, E P A-600 / 4-76-030 a$.

8. Gifford, F. A., Jr. 1976. Turbulent diffusirn-typing scheres: A review. $\therefore . \therefore 17(1): 68-86$. 
9. GeiE, H., K. J. Vogt, H. S. Ehrlich, and G. Polster. 1979. Recent results of dispersion experiments at emission heights of 50 and $100 \mathrm{~m}$, IN Froceedings of the 12 t.h Amual Slmposiur: of tire German-Sisiss Fach'erbanä flir Stranlenschutz, October 2-6, 1978, Norderney, Federal Republic of Germany (in German). Also translated in OLS-79-43, Oak Ridge National Laboratory.

10. Hanna, S. R., G. A. Briggs, J. Deardorff, B. A. Egan, F. A. Gifford, and F. Pasquill. 1977. AMS workshop on stability classification schemes and sigma curves - summary of reconmendations. Bull. Am. Meteorol. Soc. 58(12):1305-9.

11. Hoffman, F. 0., D. L. Shaeffer, C. W. Miller, and C. T. Garten, Jr. 1978. Proceedings of a Workshop on the Evaluation of Hodele usea for the Environmental Assessment of Radionuclide Releases to the Environment. Gatlinburg, Tennessee, September 6-9, 1977. CONF770901 .

12. Singer, 1. A., and M. E. Smith. 1966. Atmospheric dispersion at Brookhaven National Laboratory. Int. J. Air Water PolZut. 10(2): 125-35.

i3. Pendergast, M. M. 1976. Ëstimating iriffusion Cueffiaients from Heteorological Data. DP-MS-76-64.

14. Miller, C. W. 1978. A critique of the determination of atmospheric stability lategories for assessing airborne releases of radionuclides. Health Phys. 34(5):489-92.

15. U.S. Nuclear Regulatory Commission. 1977. Regulatory Guide 1.111, Methods for estimating atmospheric transport and dispersion of gaseous effluents in routine releases from light-water-cooled reactors, Revision 1. 
16. Briggs, G. A. 1969. Plume Fise. AEC Critical Review Series, TID-25075.

17. Moore, R. E., C. F. Baes III, L. M. McDawell-Boyer, A. P. Watson, F. O. Hoffman, J. C. Pleasant, and C. W. Miller. 1979. AIPDCS-EFi: A Computerized lethodoic- for Estimating Environmentai Concentrations and inse to lan from Aircome Releases of Radionucivies. ORNL-5532.

18. Heffter, J. L., and A. D. Taylor. 1975. A Recional-Continentai Scale Transport, Liffusion, and Leposition kidel, Part I: Tmatetors: Model. MOAA Technical Memorandum ERL-ARL-50.

19. Travis, C. C., A. P. Watson, L. M. McDowell-Boyer, S. J. Cotter, M. L. Randolph, and D. E. Fields. 1979. A Radiological Assessrent of Fadan-22L Released from Uranium Pills and other Watiural and Technologicatì Eninanced Sources. NUREG/CR-0573. ORNL/NUREG-55.

20. Van der Hoven, I. 1968. Deposition of particles and gases. pp. 202-8. IN Slade, D. (ed.), Hetcorologl and Átomic Energi ites. USAEC TID-24190.

21. Hoffman, F. 0. 1977. A reassessment of the deposition velocity in the prediction of the environmental transport of radioactivity releases. Health Phus. 34 5):437-41.

22. Miller, C. W., F. O. Hoffman, and D. L. Shaeffer. 1978. The importance of variations in the deposition velocity assumed for the assessment of airborne radionuclide releases. Healti Phys. $34(6): 730-4$

23. Heinemann, K., and K. J. Vogt. 1979. Messungen zur ablagerung and biologischen halbwertszeft von jod auf vegecation. IN

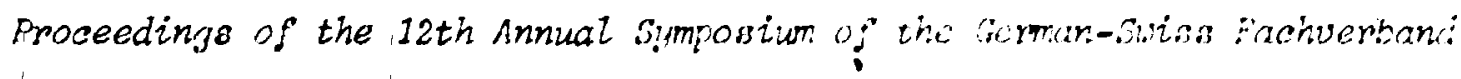
fur strahlenoshutz. Norderney, Federal Republic of Germany, October 2-6, 1978 . 
24. Hoore, R. E. 1977. The AIRDaS-II Computer Code for Estimating Paciation Dose to Han from Airboine Radionuclides in Areas Surrowanding huclear Facilities. OAn- -5245.

25. Killer, C. H., and F. O. Hoffman. A critique of methods för estiating fiune depletion and deposition of airborne radionuclides. IN Eroceedings of the 12th Ammal Symposizm of the Cermom-Suriss Fachuerband flor Strahlenschutz. Norderney, Federal Republic of Germany, October 2-6, 1978.

26. U.S. Atomic Energy Comission. 1974. Environumental Statement, Liquid Hetal Fast Breeder Reactor Progrom. MASH-1535. 


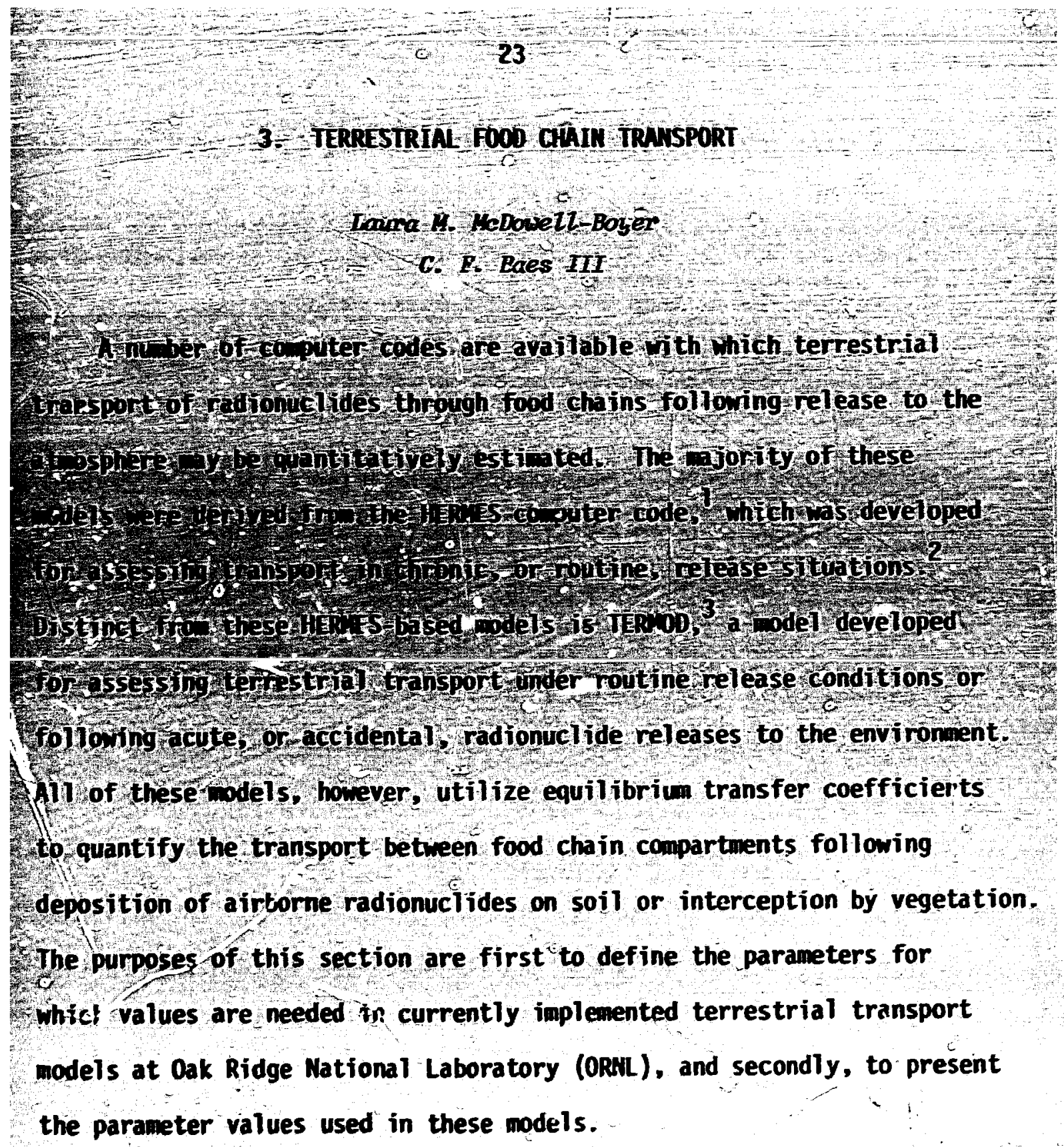

\subsection{Terrestrial Models}

Terrestrial transport models currently in use at ORNL for assessing routine radionuclide releases are implementations of models provided in the October 1977 draft of the U. S. Nuclear Regulatory Commission (NRC) Regulatory Guide 1.109, Appendix $\mathrm{C}^{4}{ }^{4}$ These latter models were originally provided for assessing transport of 'ight-water reactor effluents but have been used to assess terrestrial nuelide transport in 
general. For breedtr reactor effluents, $4 \mathrm{tay}$ be desirable to constat resuspension of nuclites following discontinution or interruption of

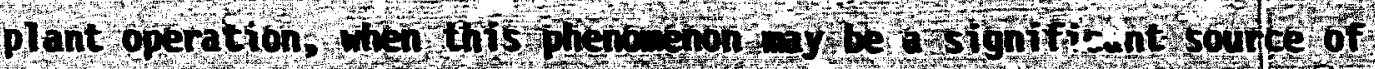

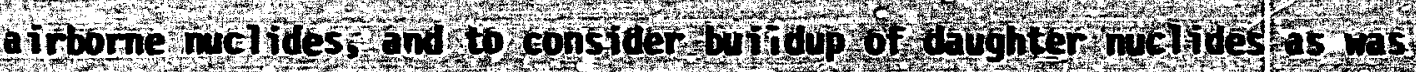

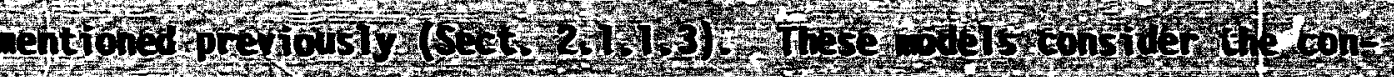

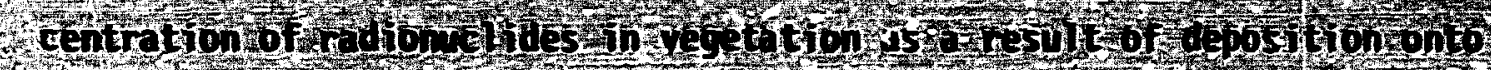

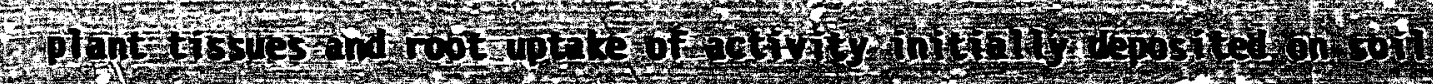

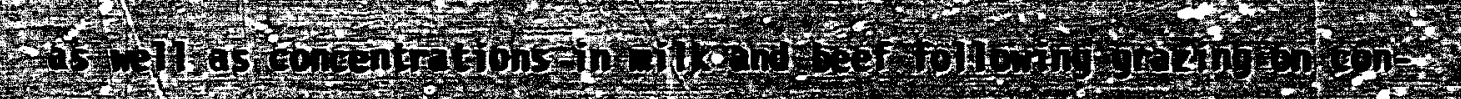

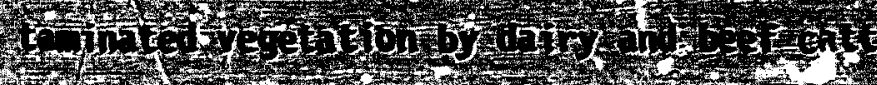

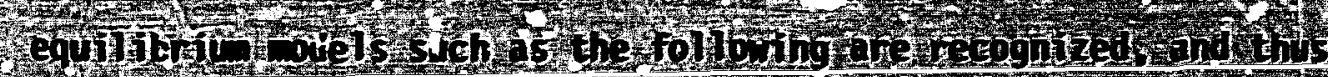

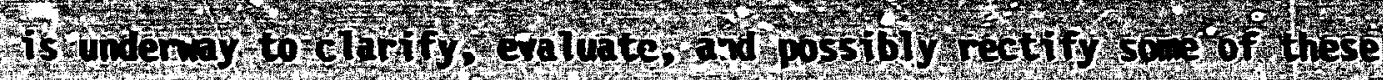
shortcomings. Hower, at present, gur discussions hil be restifeted to these currently implemented uodels.

\subsubsection{Concentrations in vegetation}

The following equation 4 is used for estimating the concentration $c_{f}^{y}(r, \theta)$ of nurlide $i$ in and on vegetation at the location $(r, \theta)$

$$
C_{i}^{V}(r, \theta)=d_{i}(r, \theta) \frac{R\left[1-\exp \left(-\lambda_{E i} t_{e}\right)\right]}{V_{V}^{\lambda_{E i}}}+\frac{B_{i v}\left[1-\exp \left(-\lambda_{i} t_{b}\right)\right]}{P \lambda_{i}} \exp \left(-\lambda_{i} t_{h}\right),
$$

where

$C_{f}^{V}(r, \theta)$ is measured in $D C f / \mathrm{kg}$.

$d_{j}(r, \theta)$ is the deposition rate of radionuclide $f$ onto ground at location $(r, \theta)$, in $\mathrm{pCt} / \mathrm{m}^{2}-\mathrm{hr}$;

$R$ is the fraction of depositing activity intercepted by crops, dtmenstonless;

$\lambda_{i}$ is the radioactive decay constant of nuclide $f_{1}$, in $\mathrm{hr}^{-1}$; 
$\lambda_{E i}$ is the effective removal rate constant for radionuclide $i$ frow crops, in $\mathrm{hr}^{-1}$, where $\lambda_{E i}=\lambda_{i}+\lambda_{w}$,

$\lambda_{w}$ is the rewoval rate constant for physical loss by weathering, in $\mathrm{hr}^{-1}$;

$t_{e}$ is the time period that crops are exposed to contanination during the growing season, in hours;

$Y_{v}$ is the agricultural productivity (yield) of the edible portion, in $\mathrm{kgin}^{2}$;

$B_{i v}$ is the concentration factor for uptake of radionuclide $i$ from soil by edible parts of crops, in $\mathrm{PCi} / \mathrm{kg}$ plant tissue per $\mathrm{pCi} / \mathrm{kg}$ diry soir ;

$t_{b}$ is the period of long-term buildup for activity in soil, in hours;

$P$ is the effective "surface density" for the top $15 \mathrm{~cm}$ of soil, in $\mathrm{kg}$ (dry soil)/ $\mathrm{m}^{2}$;

$t_{h}$ is a holdup time that represents the time interval between harvest and consumption of the rood, in hours.

Regulatory Guide 1.109 (ref. 4) makes a di,tinction between the value of $t_{e}, Y_{v}$, and $t_{h}$ appropriate for forage grasses and those appropriate for crops and leafy vegetables. The ORNL implementation of Eq. (3.1) (ref. 5) further distinguishes the $c_{i}^{v}$ calculated for pasture grasses from a $c_{i}^{v}$ calculated for fresh vegetables and produce consumed by man by inputting separate values of $B_{i v}$ and $R$ or $R / y_{v}$ for each of these categories. For pasture grasses, $Y_{v(1)}$ and $B_{i v(1)}$, based on dry weight concentrations in both vegetation and soil, are used for $Y_{v}$ and $B_{i v}$. When calculating concentrations in fresh produce consumed by man, $Y_{v(2)}$ and $B_{i v(2)}$ are used 
for $Y_{v}$ and $B_{i v}$ values, based on fresh-weight concentrations in vegetation and dry-weight soil concentrations of a nuclide.

\subsubsection{Concentrations in milk}

The concentration of radionuclide $i$ in milk Jepends upon the amount and contamination level of the feed consumed by the animal. The concentration of radionuclide $i$ in the animal's feed is calculated by use of $C$ the equation

$$
c_{i}^{v}(r, \epsilon)=f_{p}{ }_{s} c_{i}^{p}(r, \theta)+\left(1-f_{p} f_{s}\right) c_{i}^{s}(r, \theta)
$$

where

$c_{i}^{v}(r, \theta)$ is the concentration of radionuclide $i$ in the animal's feed, in $\mathrm{pCi} / \mathrm{kg}$;

$c_{i}^{p}(r, e)$ is the concentration of radionuclide $i$ on pasture grass (calculated using Eq. (3.1) with $t_{h}=0$ ), in $\mathrm{pCi} / \mathrm{kg}$;

$c_{i} r, \theta$ ) is the concentration of radionuclide $i$ in stored feeds (calculated using Eq. (3.1) with $t_{h}=2160$ hours (90 days), in $\mathrm{PCi} / \mathrm{kg}$;

$f_{p}$ is the fraction of the year that animals graze on pasture, dimensionless;

$f_{s}$ is the fraction of daily feed that is pasture grass when the animals graze on pasture, dimensionless.

Using the value of $c_{j}^{v}(r, \theta)$ calculated by use of this equation, the concentration of radionuclide $i$ in milk is estimated as

$$
\left.C_{i}^{M}(r, \theta)=F_{m} C_{i} r, 0\right) Q_{F} \exp \left(-\lambda_{i} t_{f}\right)
$$

where

$$
c_{i}^{M}(r, 0) \text { is the concentration in milk of nuclide } i \text { in } p C i / l i t e r ;
$$


$c_{i}^{v}(r, e)$ is the concentration of radionuclide $i$ in the animal's feed, in $\mathrm{pCi} / \mathrm{kg}$;

$F_{m}$ is the average fraction of the animal's daily intake of radionuclide $i$ which appears in each liter of milk, in days/liter;

$Q_{F}$ is the amount of dry feed consumed by the animal per day, in kg/day;

$t_{f}$ is the average transport time of the activity from the feed into the milk and to the receptor, in days;

$\lambda_{i}$ is the radiological decay constant of nuclide $i$, in days ${ }^{-1}$.

\subsubsection{Concentrations in meat}

The radionuclide concentration in meat (usually beef) depends upon the amount and contamination level cf the feed consumed by the animal, as in the milk pathway. Using the value of $c_{j}^{v}(r, \theta)$ as calculated in Eq. (3.2), the radionuclide concentration in meat is estimated as

$$
r_{i}^{F}(r, \theta)=F_{f} C_{i}^{v}(r, 0) Q_{F} \exp \left(-\lambda_{i} t_{s}\right)
$$

where

$$
\begin{aligned}
& C_{i}^{F}(r, \theta) \text { is the concentration of nuclide } i \text { in animal flesh, in } p C i / k g ; \\
& F_{f} \text { is the fraction of the animal's daily intake of nuclide } i \\
& \text { which appears in each kilogram of flesh, in days/kg; } \\
& C_{j}^{v}(r, \theta) \text { is the concentration of radionuclide } i \text { in the animal's feed, } \\
& \text { in } p C i / k g \text {; } \\
& Q_{F} \text { is the amount of dry feed consumed by the animal per day, in } \\
& \text { kg/day; } \\
& \lambda_{i} \text { is the radiological decay constant of nuclide } i \text {, in days }{ }^{-1} ;
\end{aligned}
$$


$t_{s}$ is the average time (days) from slaughter to consumption. For concentrations in beef, it is assumed that beef cattle are on open pasture for the same grazing periods as given for milk cattle.

\subsection{Terrestrial Transport Input Paraneters}

Following are lists of input parameter values currentiy used at ORN. in assessing terrestrial transport resulting from routine releases. These values were derived from empirical data obtained from an ongoing review of available literature, ${ }^{5}$ and represent average values over a wide range of experimental and environmenta 1 conditions. Values listed for the transfer coefficients, $B_{i v(1)}, B_{i v}(2), F_{m}$, and $F_{f}$, reflect the current status of this literature review of element-specific data pertinent to terrestrial transport, and may change when new references become available and are reviewed.

Not all transfer coefficients reported here have been evaluated in this project. Values given for these parameters are taken from other widely used documents. 6,7 The derivations of transfer coefficients for nuclides which have been evaluated are element, rather than nuclide, specific, so that the data base for some nuclides is not severely restricted.

The parameters used in the terrestrial transport models described are designed to represent annually averaged values at equilibrium over a wide range of environmental conditions. Thus, these average parameters are best suited for generic assessments, but may be used to preliminarily assess specific sites when site specific parameters are not available. Empirical data used in deriving values for these parameters may not 
always reflect annual average or equilibrium conditions, nor field conditions when laboratory or otherwise control led experiments were conducted. For technetium, appreciable uptake of the element from soil by plant roots may result in nonequilibrium soil concentrations in laboratory studies concerning technetium uptake. For this reason and because the transport model used does not consider soil loss of nuclides via crop harvest or leaching, the assessment of technetiun transport using the concentration factor approach may result in overestimates of plant concentrations. Furthermore, empirical data may not adequately reflect the true distribution of values associated with each parameter under various conditions. Thus, caution should be used in the interpretation of parameter values presented and results generated in implementation of the models.

Statistical distributions have been estimated for $Y_{v}, f_{p}, f_{s}, Q_{F}$, and $P,{ }^{8}$ and values describing the distributions for each of these parameters are provided here. For $B_{i v}, F_{m}$, and $F_{f}$, an arithmetic mean value was calculated from data obtained from each reference cited. These mean values were used in deriving an arithmetic mean for ali references collected for a particular element. Statistical distributions have not yet been developed for t'iese latter parameters. Terrestria? transport of ${ }^{3} \mathrm{H}$ and ${ }^{14} \mathrm{C}$ is addressed in Sect. 8 of this report, and thus, transfer coefficients, for these nuclides are not included in this section.

\subsubsection{Agricultural productivity by unit area, $Y_{v(1)}$ and $Y_{v(2)}$ Agriculturial productivity, in $\mathrm{kg} / \mathrm{m}^{2}$, is given in dry weight in this report for pasture grasses, $y_{v(1)}$, and in fresh weight for leafy}


vegetables and produce ingested directly b: man, ${ }^{\circ}(2)$. This meth ud of reporting parameter values for $\gamma_{v}$ has been found to de most directiy useful in the transport models used. Table 3.1 presents mean values of $\because(1)$ and ${ }_{v(2)}$ derived from the review and analysis of agricultual productivity by Hoffmari and Baes along with the: and $=$, representing the mear and standard deviation of the log-transfurmed distribution, respectively.

\subsubsection{Interception frcctions for above-grourd plant portions, $\mathrm{R}_{1}$ and $\mathrm{R}_{2}$}

The fraction of atnospherically depositing radionuclides intercepted ard initially retained on above-yruund portions of sither forage crops or leafy vegetabies and fresh produce ingested by man is symbolizec by $R_{1}$ and $R_{2}$, respectively, where $R_{1}, R_{2}=1$. The remaining fraction deposited on the soil and surfaces other than the vegetation is rierely $\left(I-R_{1}\right)$ and $\left(I-R_{2}\right)$.

Measurements of $R_{1}$ for specific values of $Y_{v}(1)$ have been made and reviewed by $H$ fffmar, and Baes and the resultant mean value of $R_{1} / Y_{V}(1)$ is giver in Table 3.1. Measuraments of the interception fraction $R_{2}$ specific for edible portions of leafy vegetables and fresh produre ingested directly by man are unavailable. It is expected that the value of $R_{2}$ will be less than that of $R_{1}$ since vegetahle crops are usually cultivated in rows. On a unit area basis, this spacing of vegetable c. ops exposes more surface soil than the dense spacing of forage crops. Therefore, a value of 0.2 for $R_{2}$, provided in the UJNRC Regulatory Guide 1.109 (rei. 4) is currently being used. These $R_{1}$ and $R_{2}$ 'alues are being used for both wet and dry deposition. 
Table 3.1. Estimated values of above-ground agricultural productivity and interception fra-tions for forage grasses and ediblc portions of vegetable crops

\begin{tabular}{|c|c|c|c|c|}
\hline Parameter & $\begin{array}{l}\text { Mean valua } \\
\left(\mathrm{kg} / \mathrm{m}^{2}\right)\end{array}$ & in & $a$ & Ret. \\
\hline $\begin{array}{l}R_{1} / Y_{v l}\left(Y_{v l} \text { measured in dry we ig̣tht- }\right. \\
\text { forage grasses): }\end{array}$ & 2.0 & .0 .61 & 0.44 & 8 \\
\hline $\begin{array}{l}y_{v 2} \text { measured in fresh weight } \\
\text { (leafy vegetables) }\end{array}$ & 1.9 & -0.73 & 0.46 & 8 \\
\hline $\begin{array}{l}Y_{v 2} \text { measured in fresh weight } \\
\text { (nonleafy vegetablcs) } \underset{:}{ }\end{array}$ & $0.5 ?$ & 0.43 & 0.52 & 8 \\
\hline $\mathrm{K}_{2}$ (vegetables) & 0.20 & & & 4 \\
\hline
\end{tabular}

${ }^{R}$, fefined as interception fraction for forage grasses.

The estimates of tie mean are the inverse of values derived by Hof fman and Baes ${ }^{8}$ (. and "are specific for $1 / Y_{V_{2}}$ ).

The distribution described by lofflian and Baes ${ }^{6}$ is based on edible portiuns of cabbage lettuce, and spinach.

The distribution described by thffman and Basef is based on edible portions of broccoli, cauliflower, green beas, lima beans, and sweet corn.

$R_{2}$ defined as interception fraction for edible portions of leafy. vegetables and fresh produce. No statistical marameters are ivallable. 


\subsubsection{Plant/soil bioaccumulation factor, $B_{\text {iv }}$}

Tablc.s 3.2 and 3.3 coníain values of $B_{i v(1)}$ and $B_{i v(2)}$, representing the transfer of elements from soil to grass leaves and portions of vegetables and produce considered edible by man, respectively. The following definitions of $B_{i v(1)}$ and $B_{i v(2)}$ apply: $B_{\text {iv }}(1)=\frac{\text { of plant at maturity }}{\text { radionuclide concenticition in so il per unit dry wt. }}$

radionuclide concentration in edible portion of $B_{\text {iv(2) }}=\frac{\text { plant at maturity per unit fresh wt. }}{\text { radionuclide concentration in soil per unit dry wt. }}$

As was mentioned previously, arithmetic means of resul ts oblained from empirical studies concerning root uptake for earh clement are currently being used for $B_{i v}$ values.

The parameter $B_{i v}$ is interpreted as the elemental concentration in plant tissues at maturity resulting from an equilibrium soil concentration to which the root are exposed during the growing season. For Tc, however, appreciable uptake of the element from soil by plant roots may result in non-equilibrium soil concentrations in laboratory studies concerning Tc uptake. ${ }^{14}$ Because no field data have been reported for Tc, the appropriate $B_{\text {iv }}$ cannot be directly derived. The $B_{\text {iv }}(2)$ for TC (Table 3.2) is simply a conversion of the $B_{i v(2)}$ value to re, resent a dry-weight concentration in forage. No distinction between plant portions or species was made in this case, due to the lack of empirical data on different plant types. 
Table 3.2. Values of $B_{i v(1)}$ [(element) forage: (element) soi] $]$ for forage and feed

Elenent $\quad B_{\text {iv }}{ }^{a} \quad$ References

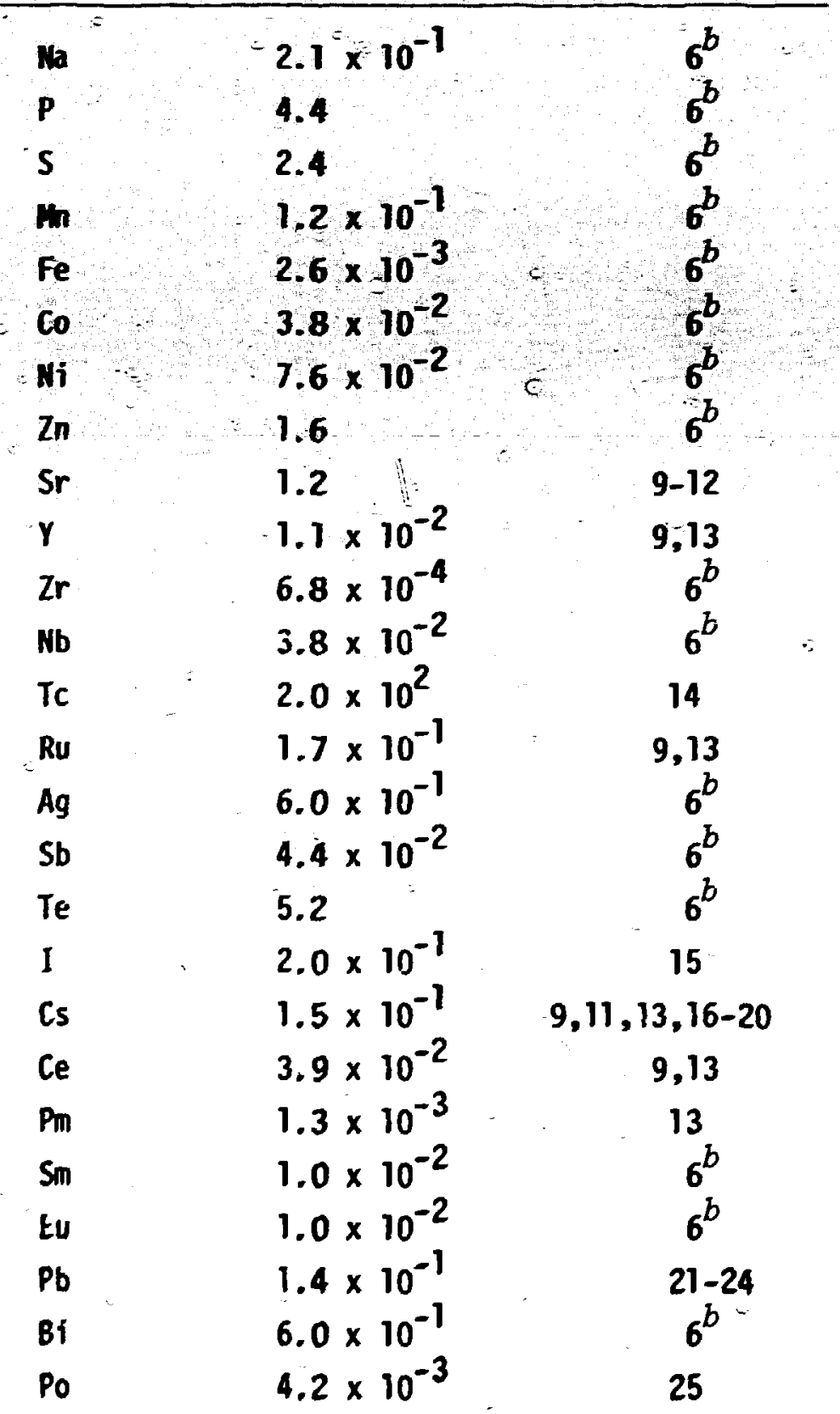


Table 3.2. (continued)

\begin{tabular}{|c|c|c|}
\hline El enent & $B_{i v(1)^{a}}$ & References \\
\hline Ra & $9.1 \times 10^{-2}$ & $26-28$ \\
\hline Ac & $1.0 \times 10^{-2}$ & $6^{b}=$ \\
\hline Th & $2.7 \times 10^{-3}$ & $29 \quad 0$ \\
\hline $\mathrm{Pa}$ & $1.0 \times 10^{-2}$ & \\
\hline U & $6.1 \times 10^{-3}$ & 29,30 \\
\hline Np & $1.0 \times 10^{-2}$ & \\
\hline Pu & $2.0 \times 10^{-3}$ & $71,13,30-34$ \\
\hline An & $2.1 \times 10^{-3}$ & $20,-31,34$ \\
\hline $\mathrm{Cm}$ & $4.8 \times 10^{-4}$ & \\
\hline \multicolumn{3}{|c|}{$\begin{array}{l}a_{B} C \\
\text { trations }\left(f_{1}\right) \text { is derived for dry-weight concen- } \\
{ }^{b} \text { Derived by converting fresh-weight plant } \\
\text { concentrations }\left(C_{p}\right) \text { to dry-ieight, ajsuming } 25 \% \\
\text { dry matter content, and dividing this value by } \\
\text { dry-weight soil concentrations, } c_{s} .\end{array}$} \\
\hline \multicolumn{3}{|c|}{$\begin{array}{l}\text { "Converted from a given fresh-weight concen- } \\
\text { tration factor to dry-weight, by assuming } 25 \% \\
\text { dry matter for plants. } \\
{ }^{d} \text { See preceding discussion. }\end{array}$} \\
\hline
\end{tabular}


Table 3.3. Values of $B_{i v(2)}[(e l e m e n t)$ edible tissue:

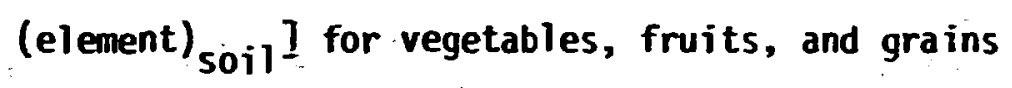

\begin{tabular}{|c|c|c|}
\hline Element & $B_{i v(2)}{ }^{a}$ & References \\
\hline $\mathrm{Na}$ & $5.2 \times 10^{-2}$ & $6^{b}$ \\
\hline $\mathbf{p}$ & 1.1 & $6^{b}$ \\
\hline$S$ & $5.9 \times 10^{-1}$ & $6^{5}$ \\
\hline$M n$ & $2.9 \times 10^{-2}$ & $6^{b}=$ \\
\hline $\mathrm{Fe}$ & $6.6 \times 10^{-4}$ & $6^{b}$ \\
\hline Co & $9.4 \times 10^{-3}$ & $6^{b}$ \\
\hline $\mathrm{Ni}$ & $1.9 \times 10^{-2}$ & $6^{b}$ \\
\hline $\mathrm{Zn}$ & $4.0 \times 10^{-1}$ & $6^{\bar{b}}$ \\
\hline $\mathrm{Sr}$ & $2.9 \times 10^{-1}$ & $9,11,12,35$ \\
\hline$=r$ & $4.3 \times 10^{-3}$ & 9 \\
\hline $\mathrm{Zr}$ & $1.7 \times 10^{-4}$ & $6^{b}$ \\
\hline Nb & $9.4 \times 10^{-3}$ & $6^{b}$ \\
\hline Tr. & $5.0 \times 10^{7}$ & $14^{\circ}$ \\
\hline Ru & $1.6 \times 10^{-2}$ & 9 \\
\hline $\mathrm{Ag}$ & $1.5 \times 10^{-1}$ & $6^{E}$ \\
\hline Sb & $1.1 \times 10^{-2}$ & 6 \\
\hline Te & 1.3 & $\epsilon^{2}$ \\
\hline I & $5.5 \times 10^{-2}$ & 15 \\
\hline Cs & $1.1 \times 10^{-2}$ & $9,11,19,20,35,36$ \\
\hline $\mathrm{Ce}$ & $6.2 \times 10^{-3}$ & 9 \\
\hline$P m$ & $2.5 \times 10^{-3}$ & $6^{3}$ \\
\hline Sm & $2.5 \times 10^{-3}$ & $6^{5}$ \\
\hline Eu & $2.5 \times 10^{-3}$ & 6 \\
\hline $\mathrm{Pb}$ & $3.9 \times 10^{-3}$ & $21,23,37,28$ \\
\hline$B i$ & $1.5 \times 10^{-1}$ & $6^{b}$ \\
\hline Po & $2.6 \times 10^{-4}$ & 25 \\
\hline
\end{tabular}


Table 3.3. (continued)

\begin{tabular}{|c|c|c|}
\hline Element & $B_{i v(z)}{ }^{a}$ & Refe -ences \\
\hline Ra & $1.3 \times 10^{-2}$ & $26,27,39,40$ \\
\hline$A C$ & $2.5 \times 10^{-3}$ & $6^{b}$ \\
\hline Th & $3.5 \times 19^{-4}$ & 41 \\
\hline $\mathbf{P a}$ & $2.5 \times 10^{-3}$ & $6^{b}$ \\
\hline $\mathbf{U}$ & $2.9 \times 10^{-4}$ & 30,41 \\
\hline Np & $2.5 \times 10^{-3}$ & $6^{b}$ \\
\hline Pu & $2.2 \times 10^{-4}$ & $11,30,33,42-44$ \\
\hline & $4.0 \times 10^{-4}$ & -29 \\
\hline $\mathrm{cm}$ & $1.7 \times 10^{-3}$ & 15 \\
\hline
\end{tabular}

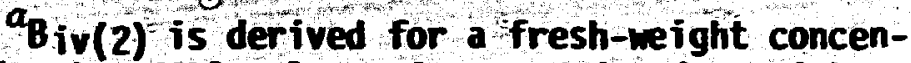
tration in edible plant tissues and a dry-weight concentration in soils.

$b_{\text {Derived by dividing the fresh-weight plant }}$ concentration $\left(C_{p}\right)$ by dry-weight soil concentrations $\left(C_{s}\right)$.

cSee preceding discussion. 


\subsubsection{Milk transfer coefficient, $F_{\text {m }}$}

The milk transfer coefficient, $F_{m}$, represents the fraction of the total daily intake of a nuclide which is transferred to a liter of the cow's milk at equilibrium. Values of $F_{m}$ can be derived from a variety of reported data according to the methodologies described by Ng et al?

Determinations of $F_{m}$ (Table 3.4) were made frr. lịterature sources reporting empirically derived results, whenever available. However, for many elements, the well-documented literature review by $\mathrm{Ng}$ et al. was the primary literature source. References in wich the chemical form of the nuclide administered orally to the cow was clearly atypical of forms found in the environment were exclided from the analysis of $F_{m}$. As for the analysis of $B_{i v}$, the values of $F_{m}$ given in Table 3.4 are element- rather than muclide-specific.

\subsubsection{Meat transfer coefficient, $F_{f}$}

The meat-transfer coefficient $F_{f}$ represents the fraction of the total daily intake of a nuclide which is transferred to a kilogram of muscle in the meat producing animal at equilibrium. It is assumed that equilibrium conditions exist when slaughter occurs.

A review of the available literature allowed the derivation of values of $F_{f}$ for beef cattle (Table 3.5). Values of $F_{f}$ based on immature cattle (less than 6 months of age) were exiuded from analysis when data for adult cattle were avaflable. Data for other ruminant species were included when literature references for cattle were unavailable. 


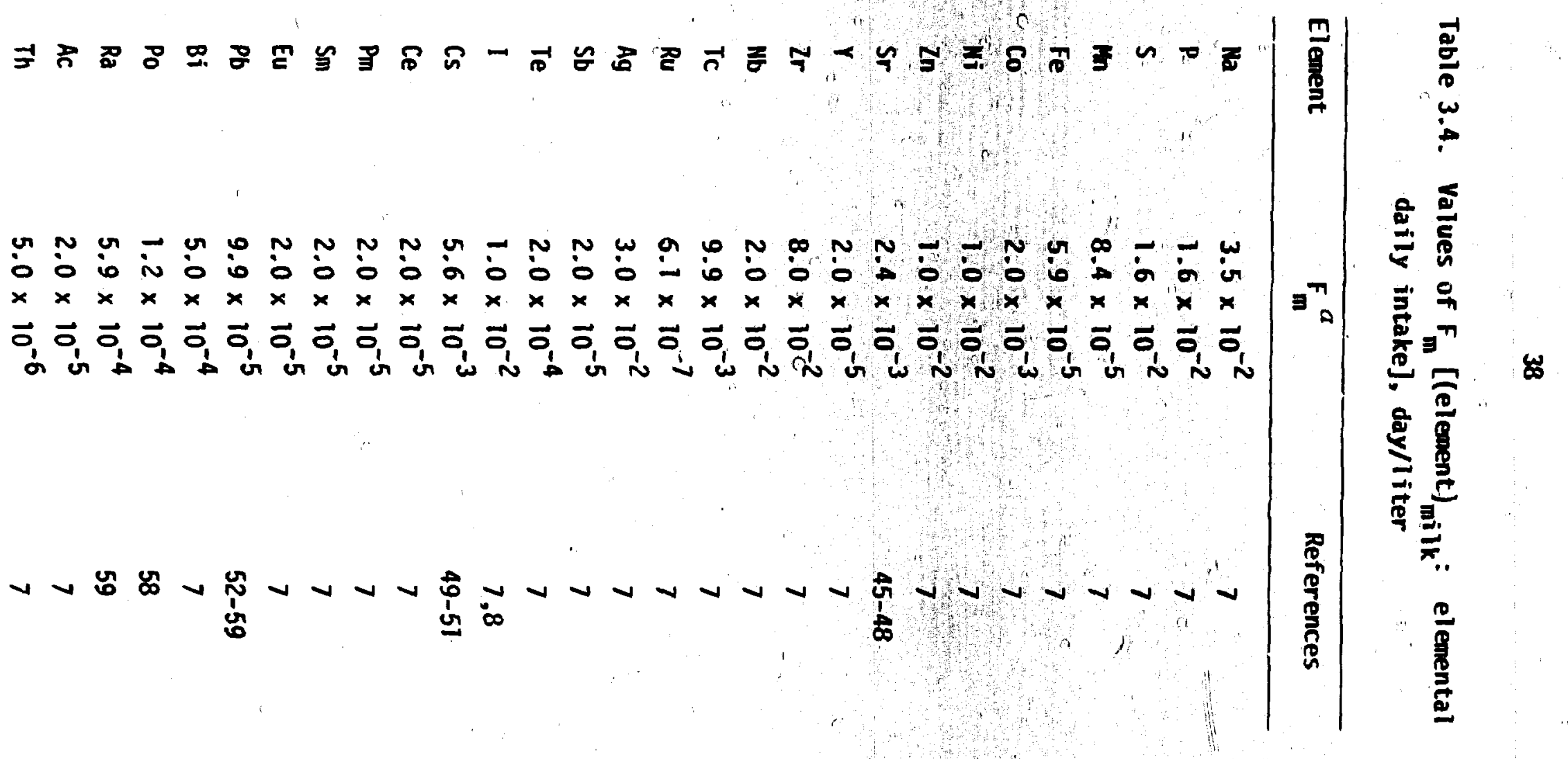


Table 3.4. (continued)

\begin{tabular}{lcc}
\hline Element & $\mathrm{F}_{\mathrm{m}}^{\mathrm{a}}$ & References \\
\hline $\mathrm{Pa}$ & $5.0 \times 10^{-6}$ & 7 \\
$\mathrm{U}$ & $1.2 \times 10^{-4}$ & 60 \\
$\mathrm{~Np}$ & $5.0 \times 10^{-6}$ & 7 \\
$\mathrm{Pu}$ & $4.5 \times 10^{-8}$ & 61,62 \\
$\mathrm{Am}$ & $2.0 \times 10^{-5}$ & 7 \\
$\mathrm{Cm}$ & $2.0 \times 10^{-5}$ & 7 \\
\hline
\end{tabular}

The $F_{m}$ is derived from fresh-weight coricentrations in milk and dry-weight concentrations in forage, feed, or hay. 
Table 3.5. Values of $F_{f}\left[(\text { element })_{\text {beef }}\right.$ : elemental daily intake], day/kg

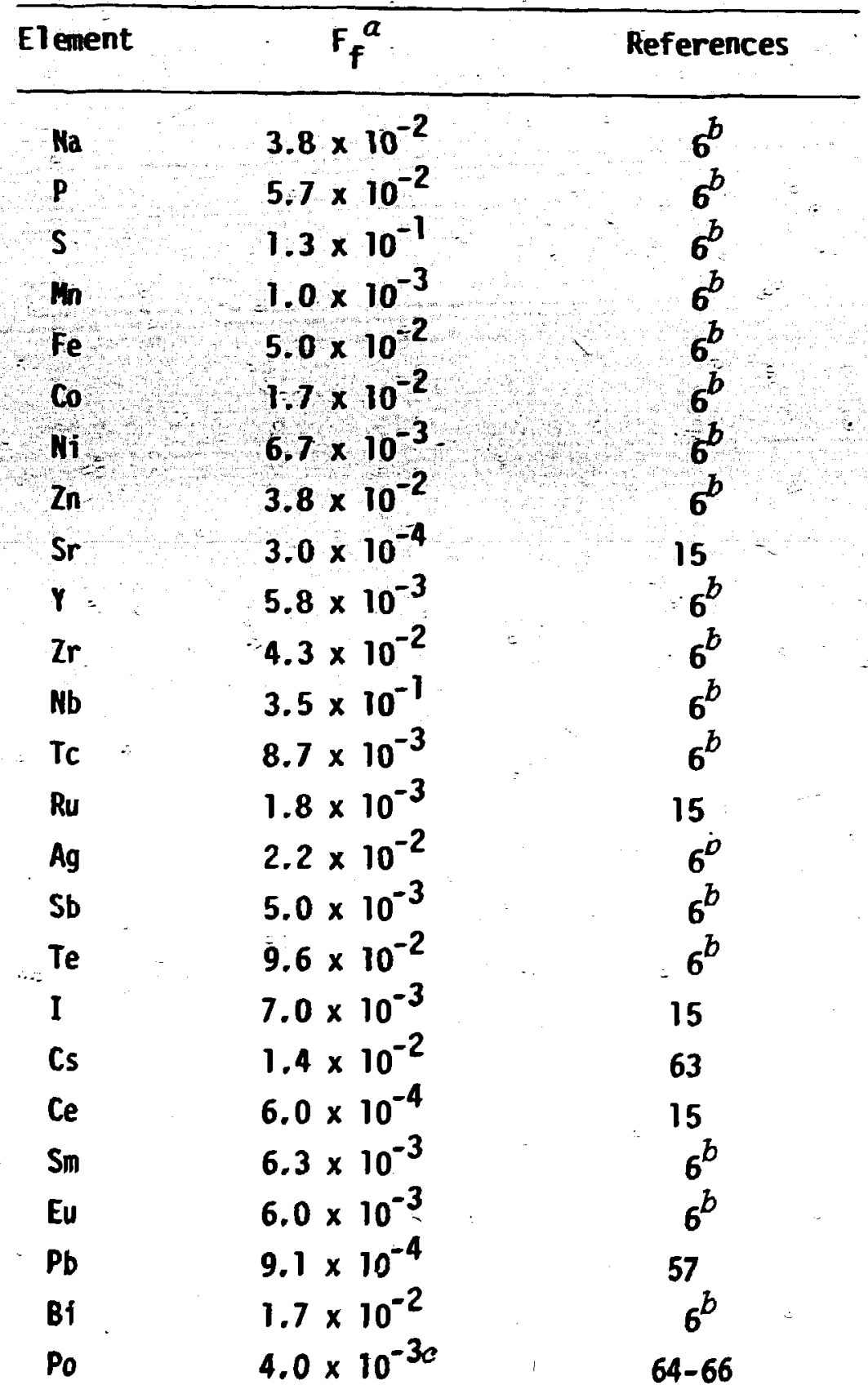


Table 3.5. (continued)

\begin{tabular}{lcc}
\hline Element & $F_{f}^{-a}$ & References \\
\hline Ra & $5.5 \times 10^{-4}$ & $65,67^{c}$ \\
$\mathrm{Ac}$ & $1.6 \times 10^{-6}$ & $d$ \\
$\mathrm{Th}$ & $1.6 \times 10^{-6}$ & $d$ \\
$\mathrm{~Pa}$ & $1.6 \times 10^{-6}$ & $d$ \\
$\mathrm{U}$ & $1.6 \times 10^{-6}$ & $d$ \\
$\mathrm{~Np}$ & $1.6 \times 10^{-6}$ & $d$ \\
$\mathrm{Pu}$ & $4.1 \times 10^{-7}$ & 15,62 \\
$\mathrm{Am}$ & $1.6 \times 10^{-6}$ & 15 \\
$\mathrm{Cm}$ & $1.6 \times 10^{-6}$ & 15 \\
\end{tabular}

$a_{\text {The }} F_{f}$ is derived from fresh-weight concentrations in beef and dry-meight concentrations in forage, feed, or hay.

$b_{\text {Derived by converting fresh-weight plant }}$ concentrations $\left(C_{p}\right)$ to dry-reight, assuming $25 \%$ dry matter content, such that $F_{f}=\frac{C_{\text {meat }} \text { (fresh) }}{C_{p}(\text { dry })} \times \frac{1}{Q_{F}}$.

${ }^{c}$ Values given are based on sheep, caribou, and reindeer data and the associated intake rates for each.

$d_{\text {values are assumed to be the same as those }}$ for curium and americium. 
$4 ?$

3.2.6 Animal feed consumption $\left(Q_{F}\right)$, grazing patterns $\left(f_{p}, f_{s}\right)$, and effective soil surface density $(P)$

Values used for the parameters $Q_{F}, f_{p}, f_{S}$, and $P$ (defined in Section 3.1) are the means of their respective statistical distributions as described by Hoffman and Bays. These means are given in Table 3.6, along with the associated $\mu$ and o for the log-transformed distribution.

3.2.7 Time parameters $t_{e}, t_{b}, t_{h}, t_{f}$, and $t_{s}$

The parameters $t_{e}, t_{h}, t_{f}$, and $t_{s}$ have all been defined in section 3.1, and the values used at ORNL are listed in Table 3.7. The values listed were taken from the draft Regulatory Guide. ${ }^{4}$ The parameter $t_{b}$, representing the period of long-term buildup for activity in soil, was not assigned a specific value. The value of $t_{b}$ is left to the user's discretion. 
Table 3.6. Values of $Q_{F}, f_{p}, f_{s}$, and $P$ used in terrestrial transpoit models at ORNL

\begin{tabular}{|c|c|c|c|c|c|c|}
\hline Parameter & Mean & म & 0 & S.D. & Units & Reference \\
\hline$Q_{F}^{a}=$ & 15.6 & & & 2.6 & $\mathrm{~kg} /$ day (dry) & 8 \\
\hline$f_{p}^{a}$ & 0.40 & & & 0.22 & & 8 \\
\hline$f_{s}^{a}$ & 0.43 & & & 0.13 & & 8 \\
\hline$p^{b}$ & 215 & 5.36 & 0.11 & $\therefore$ & $\mathrm{kg} / \mathrm{m}^{2}$ & 8 \\
\hline
\end{tabular}

${ }^{a}$ Perameter normally distributed; therefore, standard deviation (S.D.) is given.

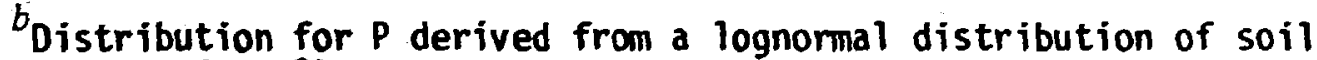
bulk density $\rho\left(\mathrm{g} / \mathrm{cm}^{3}\right)$. 
Table 3.7. values of $t_{e}, t_{h}, t_{f}$, and $t_{s}$ used in terrestrial transport models at ORNL

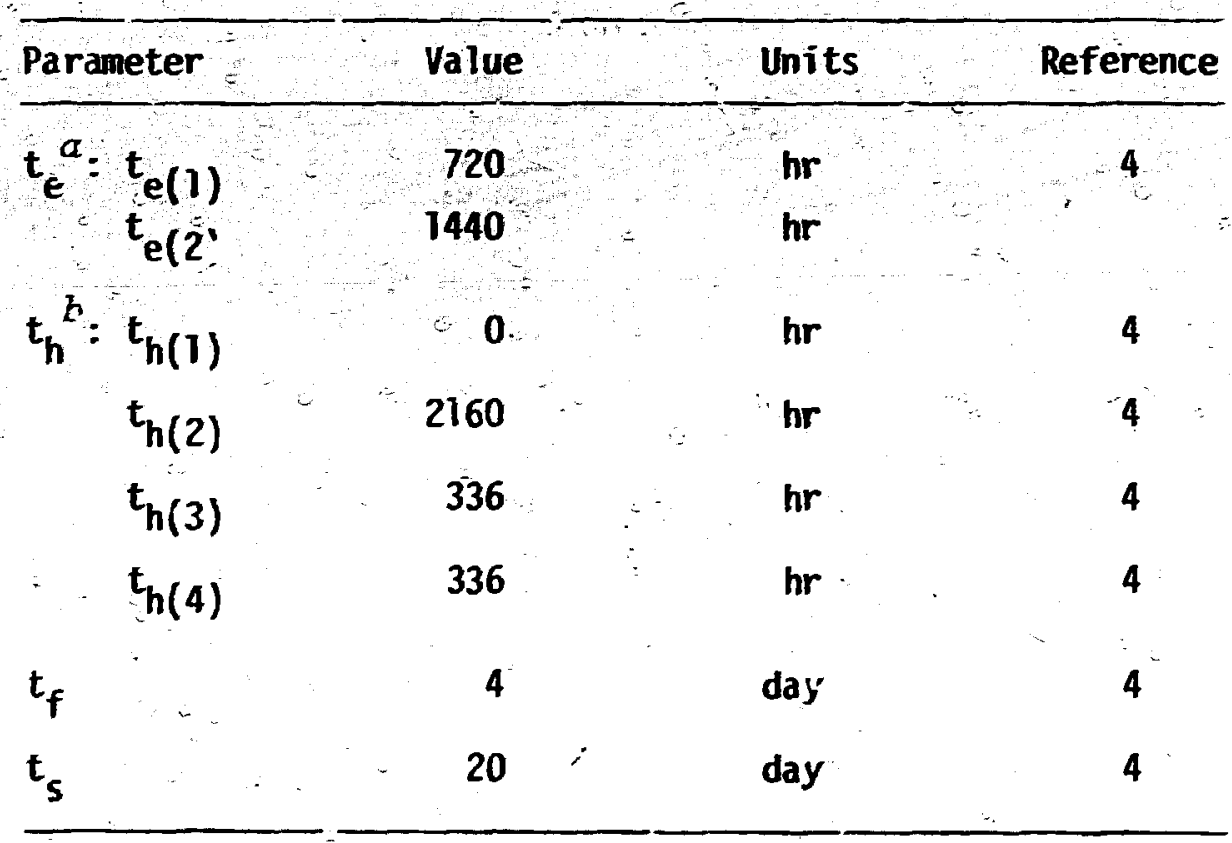

$a_{t}(1)$ applies to forage grasses; $t_{e(2)}$ applies to crops and leafy vegetables.

${ }^{b} t_{h(1)}$ applies to forage; $t_{h(2)}$ applies to stored feed for arimals; $t_{h(3)}$ applies to leafy vegetables; and $t_{h(4)}$ applies to produce. 


\section{REFERENCES}

1. Fletcher, J. F., and W. L. Dotson (compilers). 1971. EFPUES-A Digital Computer Cocie for Estimating Regional Radiological Effects from the Huctear Pcwer Industry. HEOL-TME-7I-168.

2. Hoffman, F. O., C. N. Miller, D. L. Shaeffer, and C. T. Garten, Jr. 1977. Computer codes for the assessment of radionuclides released to the environment. Fucl. Saf. 18:343-54.

3. Booth, R. S., S. V. Kaye, and P. S. Rohwer. 1971. A systems analysis methodology for predicting dose to man from a radioactively contaminated terrestrial environment. IN Proceedings of the Third Nationul Symosium on Radioicology, Oak Ridge, Ternessee, Hay 10-12, 1971. CONF-7105C1.

4. U.S. Nuclear Regulaiory Commission. 1977. Regulatory Guide 1.109. Calcilation of Annuxl Loses to $\mathrm{Km}$ From Fout, ite Releases of Reactor Effluents for the Fumpose of Evaluatiry Comp :ance win 10 CFR Fart so, Appendix I, Revision 1.

5. Moore, R. E., C. F. Baes III, L. M. McDowell-Boyer, A. P. Watson, F. O. Hoffman, J. C. Pleasant, and C. W. Miiler. 1979.

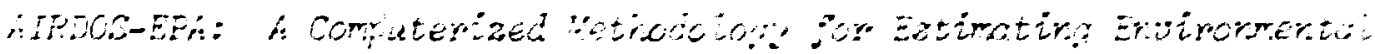

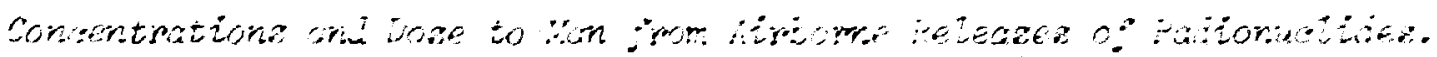
ORNL -5532 .

6. Ng, Y. C., C. A. Burton, S. E. Thompson, R. K. Tandy, H. K. Kretner, and $M$. W. pratt. 1960. Prediction of the maxillism desage to man

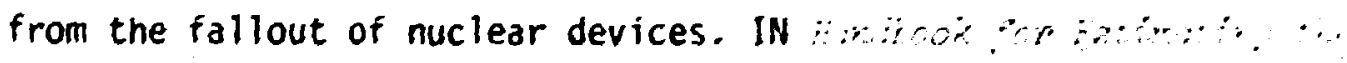

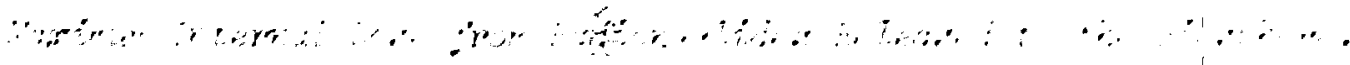
UCRL-50163, pt. IV. 
7. Mg, Y. C., C. S. Colsher, D. J. Quinn, and S. E. Thompson. 1977. Transfer Coefficients for the Prediction of the Dose to Han ria the Forage-Cow-llilk Fathay from Fadionulides Released to the Eiospiste. UCRL-51939.

8. Hoffman; F. 0., and C. F. Baes (eds.). 1979. A Statistioal Analysis of Selected Paraneters for Predicting Foad Chain Tronsport and Internal Dose of Radionaclides. Final Report. ORAL/MUREG/TM-282.

9. Romey, E. H., J. H. Neel, H. Nishita, J. H. Olafson, and K. H. Larson. f957. Plant uptake of $90_{\mathrm{Sr}},{ }^{91} \mathrm{~V},{ }^{106} \mathrm{Ru},{ }^{137} \mathrm{Cs}$, and ${ }^{144} \mathrm{Ce}$ from soils. Sotl sct. 83:369-76.

10. Romey, E. M., A. J. Steen, R. A. Wood, and U. A. Rhoads. 1966. Concentration of radionuclides by plants grown on ejecta from the sedan thermonuclear cratering detonation. pp. 391-98. IN Fadiceeological Concentrution Frociesses. Proceedings of International Symposium, Stockholm, Sweden.

11. Hardy, E. P., B. G. Bennett, and L. T. Alexander. 1977. Facionuclide uptake by Cuztivated Crops. HASL-321.

12. Arkhipov, N. P., Y. A. Fedorov, E. F. Gondar, R. M. Aleksakhin, G. N. Romanov, and L. T. Feuraleva. 1974. Predicting ${ }^{90} \mathrm{Sr}$ accumulation in the crop harvest as a result of its uptake from the soil. Sov. Soil Sci, 6(4):412-19.

13. Rediske, J. H., J. F. Cline, and A. A. Selders. 1955. The Absorption of Fiazion Products by Flants. HN-36734.

14. Till, J. E., F. O. Hoffman, and D. E. Dunning, Jr. 1978. Aaseszment of TS Feleases to the Atmosphere - A Plea for Applied Heasearch. ORNL/TM-6260. 
15. Ng, Y. C., K. A. Phillips, Y. E. Ricker, R. K. Tandy, and S. E. Thompsuni. 1978. Uetrodelog: for Assessin: Dose Comitment to Iugividuais ard to the Fopulation fror. Insestion of Ferrestrial Foods Contarinated by Emissions from a huciear Fuei Regrocessing Fiant at the Savonnch River Flant - Draft Rerort. UCID-17743.

15. Barber, D. A. 1964. Influence of soil organic matter on the entry of cesium-137 into plants. : Fature 294:1326-27.

17. Fredriksson, L., A. Eriksson, and H. Lunsjo. 1966. Studies on Plant Accumulation of Fission Products wider Swedish Conditions. VI?. uptake of ${ }^{137} \mathrm{Cs}$ in Agricutiturat Crops as Influenced by soiz Characteristics,

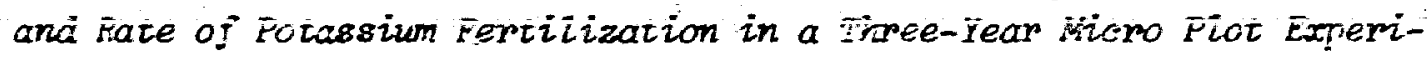
ment. Research Institute of National Defense. Stockholm. Sweden, FOA 4 Rapport A 4466-4623.

16. Fredriksson, L., H. Lonsjo, and A. Eriksson. 1969. Stzizies or Flar.t

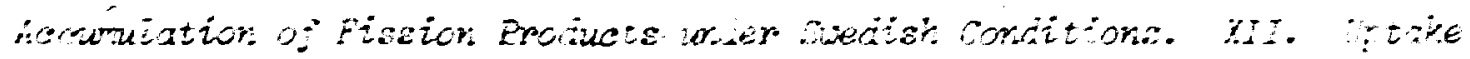

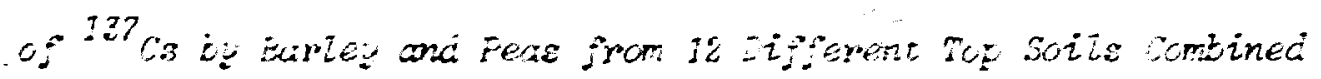

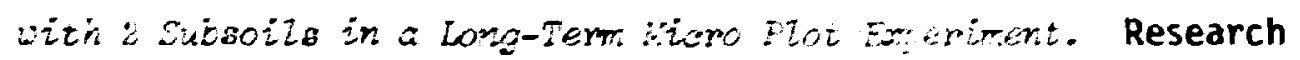
Institute of National Defense. Stockholm, Sweden, FOA 4 Rapport $C$ 4405-4428.

19. Evans, E. J, and A. J. Dekker. 1968. Comparative Cs-137 content of agricultural crops grown in a contaminated soil. Can. J. Plant Sci. 48:183-88.

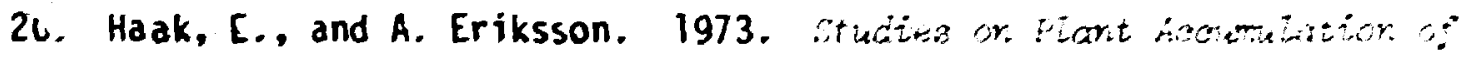

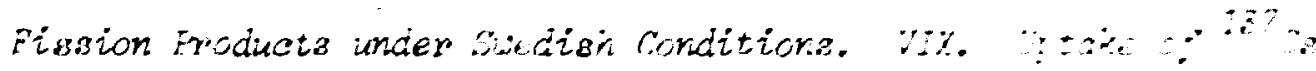

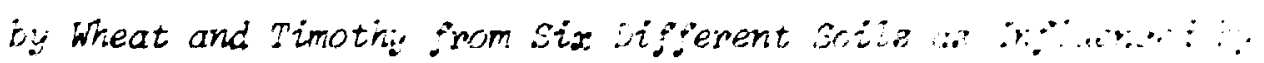

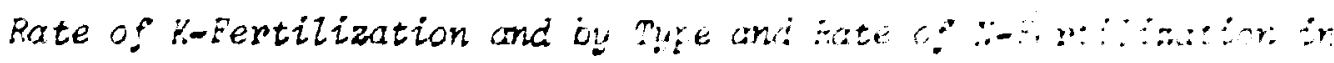
Pot Esperiments. The Research Institute of National Defence, Stockholm, Sweden, FOA 4 Rapport C 4557-A3. 
21. Dedolph, R., G. Ter Haar, R. Holtzman, and H. Lucas, Jr. 1970. Sources of $\mathrm{Pb}$ in perenniel ryegrass and radishes. Environ. Sci. Technol. 4(3):217-25.

22. Cox, H. J., and D. H. Rains. 1972. Effect of lime on Pb uptake by five plant species. $d$. Environ. Quce 2 . $1(2): 167-71$.

23. Rabinowitz, H. 1972. Plant uptake of soil and atwospheric lead in southern California. Chemosphere $1(4): 175-80$.

24. Zindah1, R. L., D. T. NcCreary, and S. M. Gmyn. 1978. Lead uptake by plants - the influence of lead source. BuzL, Bnviron. Contom: Toxicol. 19(4):431-35.

25. Matters, R. L., J. E. Johnsun, nd H. R. Hansen. 1969. A Study of Unsupported Polonium-210 for Ion Exchange in Soil and Uptake in Vegetation. C00-1733-3, Colorado State University, Fort Collins, Colo.

26. Kirchmann, R., R. Boulenger, ind A. Lafontaine. 1968. Absorption of ${ }^{226} \mathrm{Ra}$ in cultivated plants. pp. 1045-51 IN W. S: Snyder et al. (eds.). Proceedings of the IRPA Congress on Rudiation Protection. Rome, 1966, Vol. II. Pergamon Press, Mew York.

27. DeBortoli, M., and P. Gaglione. 1972. Radium-226 in environmental materials and frods. Health Phys. 22(1):43-48.

28. Taskaye Y, A. K., Y. Ya, Ovchenkov, R. M. Aleksakhin, and I. I. Shirktomova. 1977. Uptake of ${ }^{226}$ Ra by plants and changes in its state in the soil-plant tops-litterfall system. Pochvovedeniye $2: 42-48$.

29. Bondietti, E. A., J. R. Trabalka, C. T. Garten, and G. G. Killough. In press. Biochemistry of actinides: A nuclear fuel cycle perspective. IN Radtoactive Waste in Geologic Storage. ACS Sympostum Serv'ce. 
30. Adams, H. H., J. R. Buchholz, C. H. Christenson, G. L. Johnson, and E. B. Fowler. 1975. Studies of Piutonium, Americium, and ürainium in Environmental Hatrices, LA-5661.

31. Romney, E. M., H. M. Mork, and K. H. Larson. 1970. Persister.ce of plutonium in soil, plants, and small mammals. Heaith Phys. 19:487-91.

32. Price, K. R. 1972. Uptake of ${ }^{237} \mathrm{Kp},{ }^{239_{\mathrm{p}}, 245} \mathrm{Am}$, and ${ }^{244} \mathrm{Cm}$ from Soit by Tumileweed and Cheatgrass. Binl-1688.

33. Brown, K. W., and J. C. McFarlane. 1978. Plutonium uptäke by plants grom in soil containing plutonium-238 dioxide particles. Health Phys. 35:481-85.

34. Cline, J. F. 1968. Uptake of ${ }^{241}$ Am and ${ }^{239} \mathrm{Pu}_{\mathrm{bj}}$ plants. pr: 8.24-8.25. IN Thompson, R. C., and Paulette Teal (eds.). Pacific Northiest Laboratom Annual i.eport for 1967 to the USAEC Division of Biology ard Medicine, Vol. I. BNHL-714.

35. Essington, E., H. Nishita, and A. Wallace. 1962. Influence of chelates on availability of fission products to plants grown in a contaminated soil. Soil Sei. 94:96-105.

36. Schulz, R. K. 1965. Soil chemistry of radionuclides. Feaith Phys. 11:1317-24.

37. Ter Haar, G. 1970. Air as a source of lead in edible crops. Environ. Sci. Tecinot. 4(3):226-30.

38. John, M. K., and C. J. Van Laerhoven. 1972. Lead distribution in plants grown on a contaminaced soil. Environ. Lett. 3(2):111-16. 
39. Vavilov, P. P., 0. K. Papova, and R. P. Kodaneva. 1964. The

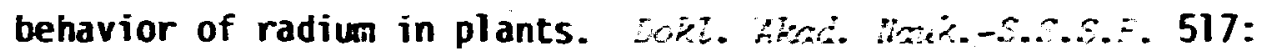
992-94 (translated abstract iset. s-i. Ast.. 19(2):2016).

40. Mordberg, E. L., V. M. Aliksandruk, G. F. Kovygin, I. I. Shevckenko, V. H. Blyumshtein, and G. F. Yushkevich. 1975. The passage of the isotopes of the uranium-radiun series into the grain of certain agricultural crops. - Sent. $40(2): 58-61$.

41. Bondietti, E. A., C. T. Gartèn, Jr., C. N. Francis, and L. D. Eyman. In preparation. Uranium and thorium in the biosphere: A review emphasizing behavior applicable to the thorium fuel cycle.

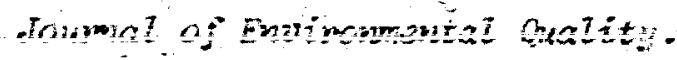

42. Sondietti, E. A., and F. H. Sweeton. 1976. Transuranic speciation in the environment. pp. 449-76. IN Trandumides in Werai

Pymposium at Gatlinburg, Tennessee, October 1976. NV0-178.

43. Schulz, R. K., G. 2. Tompkins, and K. J. Babock. 1975. Uptake of plutonium and americium by plants from soif: Uptake by wheat from various soils and effect of oxidation of plutonium added to soil.

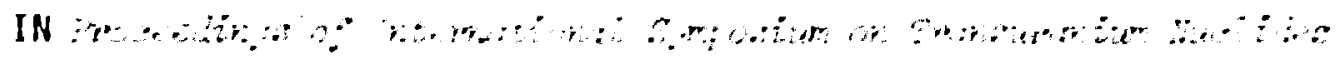
$\therefore$ tr. $\quad \therefore$ r.w. San Francisco, 17-21 November, 1975, Vienna, IAEA (1976) as quoted by Bulman, R. A. 1976. innoritration:

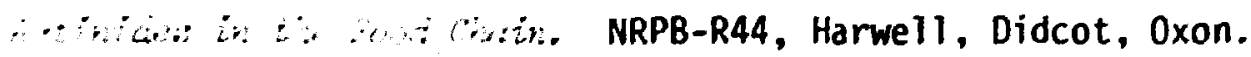
0:11 ORQ. June 1.170.

44. Dahlman, Roger C , Ernest A. Bondietti, and L. Dean Eyman. 1976. Biological pathiays and chemical behavior of plutonium and other actinides in the environment. PP. 47-80. IN Arnold M. Fitiedman (ed.). American Chemical Society, Washington, D.C. 
45. Squire, H. M., L. J. Middleton, B. F. Sansom, and C. R. Coid. 1958. Experiments on the metabolism of certain fission products in dairy cows. pp. 207-1: IN Extermann, R. C. (ed.). zaciotsotosta Seientific Eezcarch, $10 i$. IV; Pergamon Press, New York.

46. Cragle, R. G., and B. J. Demott. 1959. Strontium and calcium

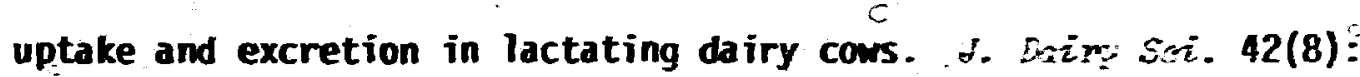
1367-72.

47. Garner, P. J., H. G. Jones, and B. F. Sansom. 1960. Fission products and the dairy cor: 2. Some aspects of the metabolism of the alkaline earth elements calcium, strontium, and barium. Biochem. j. 76:572.

48. Comar, C. L., R. H. Wasserman, and A. R. Twardock. 1:61. Secretion of calcium and strontium into milk.

49. Hawthorne, H. A. 1967. "Field studies of the transfers of ${ }^{137} \mathrm{Cs}$ from fallout to milk. pp. 77-85. IN B. Aberg and F. P. Hungate

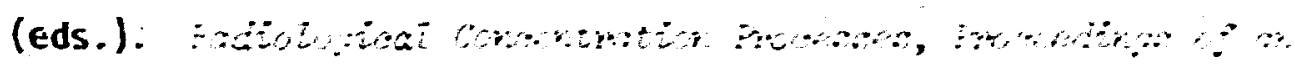

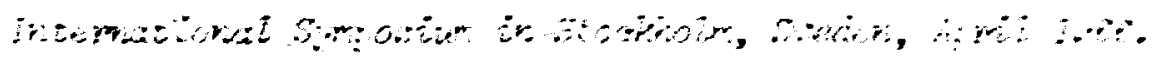

50. Hard, G. M., J. E. Johnson, and H. F. Stewart. 1965. ${ }^{137}$ CS passage from precipitation to milk. pp. 70j-10 IN A. W. K.lement, Ur.

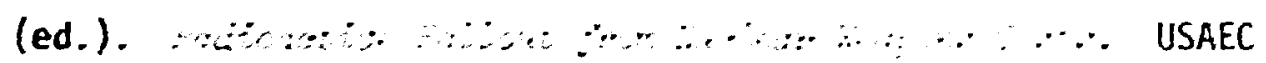
Symposium Series $=5$.

51. Johnson, J. E,, G. M. Kard, E. Firestone, and K. L. Knox. 1968. Metabolism of radioactive cesium $\left({ }^{134} \mathrm{Cs}\right.$ and $\left.{ }^{137} \mathrm{Cs}\right)$ and potassium by dairy cattle as influenced by high and low forage diets. $\therefore$ $\therefore: \leq 294: 282-88$.

52. Donovan, P. 0., D. T. Feeley, and P. P. Canavan. 1969. Lead contamination in mining areas in western Ireland II. Survey of animals, pastures, foods, and waters. $\therefore \therefore . \therefore . . .20: 43-45$. 
53. Bovay, E. 1971. Accumulation of $\mathrm{Pb}$ on vegetation along expressways. Feeding tests on dairy cows with forage contamination with $\mathrm{Pb}$. $\mathrm{pp}$. 101-17. IN Switzerland Federal Committee for Air Hygiene Investigations: The Problem of Leaded Gasoline. Bull. der Eidg. Gesundheitcmites Suppl. B, No. 3.

54. Kerin, B., and Z. Kerin. 1971. Lead contamination of milk and honey caused by industrial lead aerosols. Prot Vitae 2:61-62. IN Kettering Abstracts 9(240):206-7.

55. Stanley, R. E., A. A. Mullen, and E. H. Bretthaver. 1971. Transfer to milk of ingésted radiolead. Health Phys. $21: 211-15$.

56. Lynch, G. P., D. G. Comell, and D. F. Shith. 1974. Excretion of cadmiuit and lead into milk. pp. 470-74. IN Hoekstra, W. G., J. H. Suttie, H. E. Santher, and W. Mertz (eds.). Trace Element Metabolism in Animals - 2. University Park Press, Baltimore, Md.

57. Nelmes, A. J., R. St. J. Buxton, F. A. Fairweather, and A. E. Martin. 1974. The implication of the transfer of trace metals from sewage sludge to man. Pp. 145-53. IN Proceedings of the Iniversity of Missouri 8th Annual Conference on Trace Substances in Environmental Health.

58. McInroy, J. F. 1973. Poloniun-210 Metabolism in Ruminants. Ph.D. Dissertation. Colorado State Universtty. Fort Collins, Colo.

59. Kirchmann, R., A. Lafontaine, J. van der Hoek, and G. Koch: 1972. Comparison of the rate of transfer to cow milk of ${ }^{226} \mathrm{Ra}$ from drinking water and ${ }^{226} \mathrm{Ra}$ incorporated in hay. C. Soc. Biol. 166 (11):1557-62.

60. Chapman, T. S., and S. Hamions, Jr. 1963. Some observations concerning uranfum content of ingesta and excreta of cattle. Health Phys. 9:79-81. 
61. Sansom, B. F. 1964. The transfer of plutoinium-239 from the diet of a cow to its milk. Emit. Yet. J. 120:158-61.

62. Garten, C. T. 1978. A review of parameter values used to assess the transport of plutonium, uranium, and thorium in terrestrial food chains. Envirormental Research (in press).

63. Hard, G. M., and J. E. Jor.nson. 1965. The cesium-137 content of beef from dairy and feed-lot cattle. Health Phys. 11:95-100.

64. Beasley, T. M., and H. E. Palmer. 1966. Lead-210 and polonium-210 in biological samples from Alaska. Science 152:1062-64.

65. Holtzman, R. B. 1966. Natural levels of lead-210, polonium-210 and radium-226 in humans and biota of the Arctic. Nature 210:1094-97.

66. Hill, C. '2. 1965. Polonium-210 in man. Hature 208(5009):423-28.

67. Holtzman, R. B. 1966. ${ }^{226}$ Ra and the natural airborne nuclides $210 \mathrm{~Pb}$ and $210_{\mathrm{Po}}$ in Arctic biota. Pp. 1087-96. IN Snyder, W. S. (ed.). Froceedings of the First International Congress of Radiation. Protection. IRPA. Rome, 5.10 September, 1966. 
4. SURFACE WATER TRANSPORT

-

This section will briefly discuss models which we fee? are test suited to assess radionuclide releases from breeder reactors to hydrologic (surface water) s, stems. The models which we consider are two-dimensional, either longitudinal-transverse or longitudinal-vertical. The models also differ in their capability to account for sorptive effects on the pollutant. The Yotsukura-Sayre model (longitudinal-transverse) does not consider sorptions, but the SERATRA (longitudinal-vertical) and FETRA (longitudina?-transverse) models do consider sorption and sediment transport. These models and their parameter needs will be discussed separatel.

\subsection{Model 'ithout Sorption}

The rotsukura-Sayre model, $l$ a continuous release equilibrium model, is basicaily the same as that of Yotsukura and cobb. ${ }^{2}$ These models employ an orthogonal curviline $r$ coordinate system to describe the geomet-ical configuration of the channel. In its most fundamental form the model can be expressed as follows: ${ }^{3}$

$$
\text { uD } \frac{C_{i}}{x}-y\left(k_{y} D \frac{C_{i}}{y}\right)-(\cdot D) C_{i},
$$

where

$$
\begin{aligned}
& c_{i}=\text { concenuration of radionuclide } i\left(\mathrm{Ci} \mathrm{m}^{-3}\right), \\
& u=\text { stream velocity }\left(\mathrm{m} \sec ^{-1}\right), \\
& 0=\text { stream depth }(m), \\
& x=\text { distance downstream, }(\mathrm{m}), \\
& y=\text { distance across stream }(\mathrm{m}),
\end{aligned}
$$


$k_{y}=$ lateral turbu?ent diffusion coefficient $\left(\mathrm{m}^{2} \mathrm{sec}^{-1}\right)$, and $y=$ radioactive decay constant $=0.693$ ihalf life $\left(\mathrm{sec}^{-1}\right)$.

of these parameters, all but $K_{y}$ can be measured directly in the stream of concern. However, Yotsuk'sra and $\mathrm{Cobb}^{2}$ showed that the variable diffusion factor, $k_{y} \cup D^{2}$, may be replaced by a constant factor, $\overline{K_{y} \cup D^{2}}$ where

$$
\overline{K_{y} \cup D^{2}}=\frac{1}{Q} j_{0}^{Q} k_{y} \cup 0^{2} d q \quad,-
$$

$Q$ is the total river discharge and $q$ is the transverse cumulative discharge measured outward from the near shore. Further, Yotsukura and Cobb ${ }^{2}$ suggest that $k_{y}$ can be determined using the formula of Elder ${ }^{4}$ :

$$
k_{y}=2 u^{*}
$$

where $z$ is a unitless constant, $D$ is stream depth in $m$ and $u^{*}$ is the average shear velocity in the $y$ dimension. Therefore, the only constant which may be considered not site specific for the model is the constant 6 . The vaive of $E$ in flume studies has been shown to range from about 0.11 to $0.23 .^{2}$ A value of $=0.72$ was found in the Columbia River, ${ }^{5}$ but Fischer ${ }^{6}$ showed that secondary currents could increase the value of by as much as a factor of 10 . A value of $\delta=0.6$ has been observed in the Missouri Piver. 7

A model user who is interested in predicting the maximum concentration downstream from the same point release should choose a value of $B=0$. A zero would result in no diffusion and, as seen from $E q_{q}$. (4.1), would simplify the prediction of activity concentration to a function of decay and downstream distance. This would cffectively eliminate the consideration of transverse (or lateral) distance and maximize the activity concentration at any point in micistrean. 
A model user who is not interested in a conservative estimate will be facer with deciaing which value of $E$ to use. From the review of Yotsuki.ra and $\mathrm{Cobb}^{2}$ we conclude that $\$$ may range from approximately 0.1 to 0.72 (and perhaps higher). He wculd suggest, then, that a user interested in accurate predictions of pollutant concentrations in water should use a value of ecgreater than 0.1 and less than 1.0 .

\subsection{Models with Sorption}

If the pollutant being assessed is not in a soluble form or has a marked tendency to adsorb to sediments, as do many actinides, the user may wish to use a model which is capable of predicting sediment or particulate. contaminant transport. For such an application, we suggest considering usage of the FETRA model discussed by Onishi and Wise ${ }^{8}$ in spite of the large number of input parameters it requires. FETRA and a similar model, SERATRA, ${ }^{9}$ both estimate sediment and pollutant concentrations downstream from some release site as a function of time after the release. However, SERATRA estimates concentrations longitudinally and vertically, while FETRA considers longitudinal and lateral (transv srse) distribution of the pollutant. These models are both much more complex than the Yotsukura model mentioned above, and therefore, SERATRA and FETRA will be discussed in general terms, neglecting specific parameters.

Both SERATRA and FETRA are time-dependent models which consist of three submodels: (1) a sediment transport model, (2) a dissolved contaminant transport model, and (3) a particulate contaminant transport model.

The sediment transport sections of FETRA and SERATRA are capable of accouriting for effects of: (1) convection and dispersion, (2) fall 
velocity and cohesiveness, (3) deposition on the river bottor, (4) river bed erosion, and (5) tributary fiow. Necessary data include: (1) concentration of each of $j$ sediment types for unit volume of water; (2; time after release; (3) longitudinal, lateral, and vertical velocities; (4) particle fall velocity of $j$ sediment types; (5) lo'gitudinal, - Tater $>1$, and vertical diffúsion coefficients of $j$ sediment types; (6) rivér width; (7) flow depth; (8) sediment deposition and erosion rates for $j$ sediment types; and (9) estimates of several coefficients dealing with erodibility, critical shear stress, and impaction probability on the river bottom for each of $j$ sediment types.

Basically: the same data are required for the particulate contaminant transport submodel. However, this submodel also takes into account the adsorption and desorption of a dissolved pollutant by sediments and removal of the pollutant by chemical or biological means.

The dissolved pollutant submodels of FETRA and SERATRA also account for convection and dispersion of pollutant, adsorption and desorption of pollutant from water, chemical and biological decay of pollutant, and the effects of tributaries. In addition to data required for the two previous submodels, the dissolved contaminant model needs information about the following: (1) distribution coefficient between dissolied and particulate contaminant adsorbed on each of the $j$ sediment types; (2) amount of particulate pollutant per unit mass of $j$ sediments; (3) mass of contaminant dissolved per unit volume of water; (4) longitudinal, lateral, and vertical diffusion coefficients for dissolved contaminant; and $(5)$ chemical and biological decay rate of contamiriant.

As the reader has likely noticed, the amount of input data needed for the FETRA and SERATRA models is great. 'Given the diversity of input 
59

data and the difficulty in measuring some of the input parameters, it is [-ubtf'sl that either. FETRA or SERATRA would be used for a onetime assessment of a pollutant release into a river, such is an accidental release units prior input data had previously been collected. However, $\because$ the model input data were available for a particular site, the models would be well sited tn estimate pollutant transfer downstream following some accidental release. We suggest FETRA and SERATRA for those situations in which pollutant sorption to sediments may be important or when the pollutant is a particulate. 


\section{REFERENCES}

1. Yotsukura, :. and W. W. Sayre. 1976. Transverse mixing in natural channels. atros. $12(4): 695-704$.

2. Yotsikura, N. and E. D. Cobb. 1972. Transverse diffusion of solutes

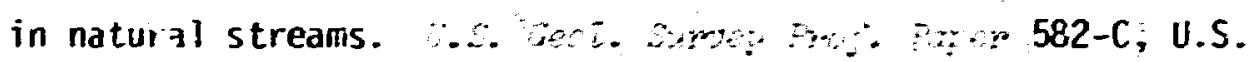
Government Printing office.

3. U.S. Nucleir Regulatory Comission. 1977. Regulatory Guide 1.113.

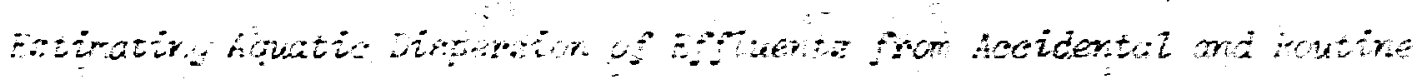

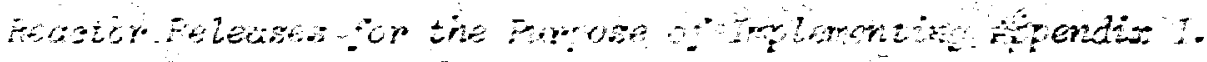

+. Elder, 1. W. 1959. The dispersion of marked fluid in turbulent shear flow. $\because$ ar. 5(4):544-60.

5. Glover, R. E. 1964. Dispersion of dissolved or suspended materials

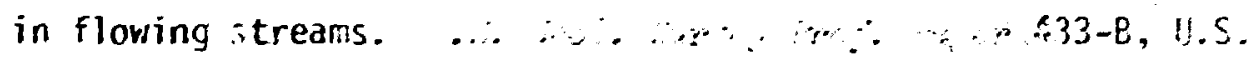
Government Printing Office.

6. Fischer, H. E. 1969. The effect of berids in dispersion in strearis. n........... 5(2):496-506.

7. Yotsukura, N., H. B. Fischer, and W. W. Sayre. 1970. Measurement of mixing characteristics * the Misscuri River between Sisu City, Sowa

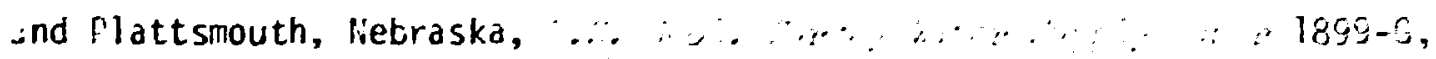
U.S. Government Printing office.

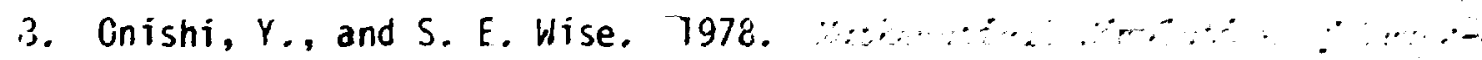

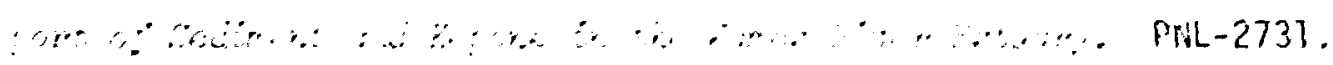

G. Unishi, Y. 1977.

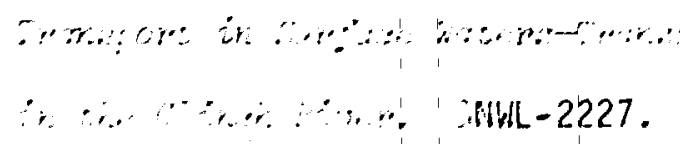


10. Onishi, Y. 1977. Kathematical Simulation of Sediment and Fadionusicie Transport in the Colimbia River. BMM-2228. 
5. AQUATIC FOOD CHAIN TRANSPORT

Poterta \% Fror

\subsection{The Basic Model}

Medels that describe ine transport of radionuclides from liquid effluents to man via aquatic foods generally take the form ${ }^{l-3}$

$$
R_{a i j p}=U_{a p} C_{i} B_{i p}{ }^{B_{i a j}},
$$

\section{where}

$$
\begin{aligned}
R_{a i j j}= & \text { dose to organ } j \text { of an individual of age group a } \\
& \text { due to nuclide } i \text { via aquatic food } p \text { (millirem/year), } \\
U_{a p}= & \text { ingestion rate of aquatic food } p \text { by an individual of } \\
& \text { age a ( } \mathrm{kg} / \text { year), } \\
C_{i}= & \text { concentration of radionuclide } i \text { in water ( } p C i / l i t e r), \\
B_{i p}= & \text { the equilibrium ratio of the concentration of radionuclide } \\
& i \text { in aquatic food } p \text { to its concentration in water ( } i \text { iter } / \mathrm{kg} \text { ), } \\
D_{a i p j}= & \text { dose conversion factor for age group a, radionuclide } i, \\
& \text { aquatic food } p, \text { and organ } j \text { (millirem/pCi). }
\end{aligned}
$$

Methow of calculating $C_{i}$ are considered in Sect. 4 of this report;

$U_{a p}$ is considered in Sect. 6, and $D_{a i p j}$ is considered in Sect. 7. The bioaccumulation factor $B_{i p}$ is consioered in the remainder of this section.

\subsection{The Bioaccumulation Factor}

The transfer of radionuclides from contaminated water to human food through various tropic levels of aquatic life is represented by a single parameter, the bioaccumulation factor, $B_{i p}$. Its value is usually tabulated by nuclide for several tropic levels in freshwater and seawater. ${ }^{4-7}$ 
Reported values for $B_{i p}$ vary commonly by an order of magnitude-in some cases by three and four orders of magnitude. Examples of the larger range of values are cesium in freshwater fish and managese in both freshwater and marine malluses. ${ }^{5-7}$

The accumulation of radionuclides in aqiatic food occurs by complex interactions of biological, chemical and physical factors including some that can confound the assumption of equilibrium in the definition of $B_{\text {ip }}$ (see 5.1). In addition, although nuclides concentrate in different tissues, the tabulations do not always designate the tissue. When different $B_{i p ' s}$ of an organism are known, the values given here refer to edible parts. 5 Stable elements and their congences markedly affect the accumulation of radionuclide in piota. Extensive studies of ${ }^{89} \mathrm{Sr},{ }^{90} \mathrm{Si}$. (and ${ }^{137} \mathrm{Cs}$ ) have shown their ecological accumulation to be usually inverse functions of congenes stable element concentration, of calcium (and potassium) in both aquatic and terrestial biota. $8-11$

The $B_{i p ' s}$ for $C S$ and $S r$ in frestrwater fish have been correlated from data from a number of studies in natural waters by Vanderploeg et al. $B_{\text {ip }}$ values may be estimated from site-specific concentrations of potassium and calcium in water according to the following:

1. -50 ppin sediment in infiltered water piscivorous fish, $\mathrm{B}_{i p}(\mathrm{Cs})=1.5 \times 10^{4} /[\mathrm{K}]_{\mathrm{w}}$ nonpiscivorous fish, $B_{i p}(c s)=5 \times 10^{3} /[k]_{w}$

2. $50 \mathrm{ppm}$ sediment in unfiltered water.

piscivoruss fish, $B_{i p}(C s)=3 \times 10^{4} /[\mathrm{K}]_{w}$ nonpiscivorous fish, $B_{i p}(C s)=1 \times 10^{3} /[K]_{W}$ 


\section{3. fish muscle}

$$
B_{i p}(S r)=\exp \left\{5.18 \pm 1.11(\text { s.e. })-1.21 \pm 0.37 \text { (s.e.) } \ln \left[C_{a}\right]_{w}\right\} \text {. }
$$

where

$[K]_{w}=$ equilibrium concentration of $K$ in the water (ppm),

$[\mathrm{Ca}]_{w}=$ equilibrium concentration of $C_{a}$ in the water $(p p m)$, and

s.e. = standard error of the mean.

Site-specific information should te used in estimating bioaccumulation factors, especially for cesium in freshwater environments, if precision of one order of ulagnitude is desired.

In the absence of site-specific information, values of $B_{\text {ip }}$ for different nuclides have been tabulated. Table 5.1 presents the results of an analysis ${ }^{12}$ of $B_{i p}$ values for strontium, iodine, and cesium in freshwater finfish taken from vanderploeg et al. 7 Values of $B_{\text {ip }}$ currently used at Oak Ridge Nationa? Laboratory ${ }^{13}$ for both treshwater and marine species are shown in Table 5.2. The tabulation corsists of selected values from Thompson $\epsilon^{+}$al. ${ }^{5}$ Most of these values have been calculated from separate analyses of the stable elements in biota and water that may not have originated in the same part of the world. Althuugh these values are reasunabie as shown by comparisun with experiments in which equiiibrium between water and biota was attempted or attained, site. specific values may possibly erhibit wide variations from then.

Accidental releases have not been judged important in aqieous food pathway assessments because of the availability of time for counter mearures to be taken. A stiudy was made of the accidental conseruences of a nuclear submarine cullision with a surface vessel in a harbor. The 
authors conclude that a single meal of fish or shell fish consumed before the food supply was monitored would result in exposure within the range of "acceptable" dose levels. 14 
Table 5.1 Results of a statistical analysis of B (1iters/kg) for $S r$. I, and Cs in
freshmater finfish

\begin{tabular}{cccc}
\hline Element & $\mu$ & $\sigma$ & $\bar{\chi}$ \\
\hline$S r$ & 2.4 & 1.8 & 60 \\
$I$ & 3.5 & 0.61 & 41 \\
$C s$ & 7.2 & 0.86 & 1.900 \\
\hline$c_{\text {Heffma: , F. }}$ 0. (ref. 12).
\end{tabular}


Table 5.2 Values of $B_{i p}(1$ iter $/ \mathrm{kg})$ for various elements in aquatic foods ${ }^{a}$

\begin{tabular}{|c|c|c|c|c|c|}
\hline \multirow{2}{*}{\multicolumn{2}{|c|}{ Element }} & \multicolumn{2}{|c|}{ Freshater } & \multicolumn{2}{|l|}{ Marine } \\
\hline & & Invertebrates & Fish & Invertebrates & Fish \\
\hline $\mathrm{Na}$ & & $1.7 E+01$ & $2.0 E+01$ & I.OE 00 & $1.0 \mathrm{E} 00$ \\
\hline $\mathbf{P}$ & & $1.0 E+05$ & $1.0 E+05$ & $1.0 E+04$ & $1.0 E+04$ \\
\hline 5 & & $1.0 E+02$ & $7.5 E+02$ & $4.0 E 00$ & $4.0 E 00$ \\
\hline$m^{b}$ & & $1.0 E+05$ & $3.2 \mathrm{E}-01^{c}$ & $5.0 E+04$ & $3.0 E+03$ \\
\hline Fe & & $3.2 E \pm 03$ & $1.0 E+02$ & $20 E+04$ & $1.0 E+03$ \\
\hline $\mathrm{Co}^{b}$ & & $1.0 E^{\circ}$ & $3.0 E 02$ & $1.0 E+04$ & $1.0 E+02$ \\
\hline $\mathrm{Ni}$ & & $1.0 E+02$ & $1.0 E+02$ & $1.0 E+02$ & $5.0 E+02$ \\
\hline $\mathbf{Z n}$ & & $1.0 E+04$ & $1.0 E+03$ & $5.0 E+04$ & $5.0 E+03$ \\
\hline $5 r^{b}$ & r & $3.0 E+02$ & & I.OE 00 & $1.0 E 00$ \\
\hline$Y$ & & $1.0 E+03$ & $2.5 E+01$ & $=1.0 E+02$ & $3.0 E+01$ \\
\hline $\mathrm{Zr}$ & & 6.7E 00 & $3.3 E 00$ & $1.0 E+02$ & $3.0 E+01$ \\
\hline $\mathbf{N b}$ & & $1.0 E+02$ & $3.0 E+04$ & $2.0 E+02$ & $1.0 E+02$ \\
\hline TC & . & $5.0 E 00$ & $1.5 E+01$ & $1.0 E+02$ & $1.0 E+01$ \\
\hline $\mathbf{R u}$ & & $3.0 E+02$ & $1.0 E+01$ & $1.0 E+02$ & $3.0 E 00$ \\
\hline $\mathrm{Ag}$ & & $7.7 E+02$ & $2.3 E 00$ & $5.0 E+03$ & $1.0 E+03$ \\
\hline Sb & & $1.0 E+01$ & 1. OE OO & $1.0 E+03$ & $1.0 E+03$ \\
\hline Te & 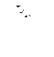 & $6.1 E+03$ & $4.0 E+02$ & $1.0 E+02$ & $1.0 E+01$ \\
\hline$I^{b}$ & & $4.0 E+02$ & 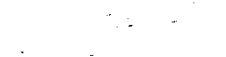 & $1.0 E+02$ & $2.0 E+01$ \\
\hline$C s^{2}$ & & $1.0 E+03$ & 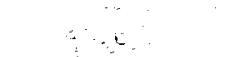 & $5.0 E+01$ & $3.0 E+01$ \\
\hline $\mathrm{Ce}$ & & $1.0 E+03$ & $2.5 E+01$ & $1.0 E+02$ & $3.0 E+01$ \\
\hline Pm & & $1.0 E+.03$ & $2.5 E+01$ & $1.0 E+03$ & $1.0 E+02$ \\
\hline $\mathrm{Pb}$ & & $1.0 E+02$ & $3.0 E+22$ & $1.0 E+03$ & $3.0 E+02$ \\
\hline $\mathrm{Bi}$ & & $\therefore .0 E+05$ & $1.5 E+01$ & $1.0 E+05$ & $1.5 E+01$ \\
\hline Po & & $2.0 E+04$ & $5.0 E+01$ & $2.0 E+04$ & $-2.0 E+03$ \\
\hline $\mathbf{R a}$ & & $2.5 E+02$ & $5.0 E+01$ & $1.0 E+02$ & $5.0 E+01$ \\
\hline$r r_{i}$ & & $5.0 E+02$ & $3.0 E+01$ & $2.0 E+03$ & $1.0 E+04$ \\
\hline $\mathrm{Pa}$ & & $1 . i E+02$ & $1.1 E+01$ & $1.0 E_{1}+01$ & $1.0 E+01$ \\
\hline y & $\therefore$ & $1.0 E+02$ & $1.0 E+01$ & $1.0 E+01$ & $1.0 E+01$ \\
\hline$N \bar{p}$ & & $4.0 E+02$ & $1.0 E+01$ & $1.0 E+01$ & $1.0 E+01$ \\
\hline $\mathrm{Pu}$ & $\therefore$ & $1.0 E+02$ & $3.5 E+02$ & $1.0 \mathrm{E}+.02$ & $3.5 E \quad 00$ \\
\hline$A m$ & & $1.0 E+03$ & $2.5 E+01$ & $1.0 E+03$ & $2.5 E+01$ \\
\hline $\mathrm{Cm}$ & & $1.0 E+03$ & $2.5 E+01$ & $1.0 \mathrm{E}+03$ & $2.5 E+01$ \\
\hline
\end{tabular}




\section{REFERENCES}

1. Soldat, J. K., R.. A. Baker, and J. P. Corley. 1973. Applications of a general computational model for composite envíronmental radiation doses. pp. 483-98. IN Envirormental Behavior of Rodionuclides Released in tre Huciear Industry, Sy,mposizon Proceedings. International Atomic Energy Agency, Vienna, Austria.

2. Lyon, R. B. 197.6. RAMU: A System of Computer Erograns for Radionuclide Pathway Analysis Calculations. Atomic tnergy of Canada, Limited, Püblication AECL-5527.

3. U.S. Nuclear Regulatory Cormission. 1977. Regulatory Guide 1.109. Calculation of Annual Doses to Man From Routine Releases of Reactor Effluents for the Purpose of Evaluating Compliance with 10 CFF Part 50 , Appendis. Revision 1.

4. Polikaspov, G. G. 1973. "Radioecology of Marine Plants and Animals," Radioecology, Eds. V. Hi. Klechkostii, G. G. Polikaspov, and R. M. Aleksakhin, J. Wiley \& Sons, New York.

5. Thomas, S. E., C. A. Burton, D. J. Quinn, Y. C. Ng. 1972. Concentration Factors of Chemical Elements in Edibie Aquatic Organisms. UCRL-50564 Rev. Lawrence Livermore Laboratory, Livermore, California.

6. Jinks, S. M: and M. Eisenbud. 1972. "Concentration Factors in the Aqueous Environment," Rad. Data Rep. 13 243-247.

7. Vanderploeg, H. A., D. C. Parzyck, W. H. Wilcox, J. R. Kercher, and S. V. Kaye. 1975. Bisaceromulation Factors for Radionuclides in Freshwater Biota. ORNL-5002. 
8. Templeton, H. L. and V. B. Bowen. 1964. "The Relatioriship Between concentrations of Caldium, Strontium and Strontium-90 in Wild Brown Trout SALMOTRUTAL and the Concentrations of Stable Elements in: Some Waters of the United Kingdon and the Implications in Radioecological Health Studies," Int. J. Air Wat Pall . $\underline{8}$ 49-75.

9. Ettenhuber, E. and W. Röhnsch. 1975. "The Fish/Water Accumulation Factor-An Important Parameter for Determining the Environmental Capacity of Surface Hater," in Radiological Impacts of Releases from. Huciear Facilitie into Aquatic Envirorments, STI/PUB/406 IAEA, Vienna.

10. Fleishman, D. G. 1973. "Accumulation of Artifical Radionuclide in Freshwater Fish," in Radisecology 347-370.

11. Russell, R. S. 1966. Radioactivity and Human Diet, Chaps. 2, 9, 11, 15, 18, Pergamon Press, New York.

12. Hoffman, F. 0. 1979. Bioaccumulation factors for freshwater fish. IN Hoffman, F. 0., and C. F. Baes III (eds.), A Statistical Analysis of Selected Parmeters for Predicting Food Chain Transport and Internal Dose of Radionuclides. ORNL/NUREG/TM-282.

13. Killough, G. G., and L. R. Mckay. 1976. A Methodology for Calculating Radiation Doses from Radioactivity Released to the Enviroment. ORNL -4992.

14. Preston, A and D. F. JefFries. "An Evluation of the Public Health Aspects of a Marine Accident in Coastal Waters," in Proceedings of the Fourth International Symposizm on the Transport of Hazardous Cargoes by Sea and Intand Waterway, U566-D-24-76 (also AD-A-023 505) pp. 325-338. 


\section{ADULT DIETARY INTAKE AND INHALATION RATES}

Elizabeth H. Fupp

The internal radiation dose to man as a result of exposure to contaminated air, water, and/or food is determined in part by the amount of material which is incorporated into the human body via food and inhalation pathways. Dietary parameters and inhalation rates considered in this study are as follows:

1. the consumption of milk, $U_{\text {ap }}^{M}$ (1iter/year);

2. the consumption of water, $U_{a p}^{H}$ (1iter/year);

3. the consumption of fruits, leafy vegetables, below-ground vegetables, other vegetábles, grain, beef, other meats and poultry, finfish, and shellfish, $U_{a p}^{F}(\mathrm{~kg} /$ year $)$;

4. the volumetric inhalation rate, $U_{\text {ap }}^{A}\left(\mathrm{~m}^{3} / \mathrm{year}\right)$.

Table 6.1 presents the annual average values of ingestion and inhalation rates for adult individuals. While these factors are undoubtedly related to age and individual variability, only adult values are given in Table 6.1 because the internal dose conversion factors provided in Sect. 7 are only for adult individuals. A more detailed analysis of human dietary intake and inhalation rates is given elsewhere. ' 
Table 6.1. Estimated values of ingestion and inhalation rates for adult individuals

\begin{tabular}{lcc}
\hline \multicolumn{1}{c}{ Item } & Average value & Reference \\
\hline & $--k g /$ year- & \\
Fruits & 68 & 2 \\
Leafy vegetables & 18 & 3 \\
Below ground vegetables & 28 & 2 \\
Other vegetables & 45 & 2 \\
Grains (flour equivalent) & 35 & 2 \\
Beef & 32 & 2 \\
Other meats, poultry & 63 & 2 \\
Finfish & 4.4 & 8,9 \\
Shellfish & 1.3 & 9 \\
& --1 iters/year-- & 2 \\
Milk ${ }^{a}$ & 112 & 10 \\
Tap water & 93 & 10 \\
Other beverages & 400 & 11 \\
Inhalation rate & $3 /$ year-- & \\
\hline
\end{tabular}

anclude all milk drinks, fresh cream, ice cream, and small amounts of cheese. 


\section{REFERENCES}

1. Rupp, E. M. 1979. Annual dietary intake and respiration rates. IN Hoffman, F. O., and C. F. Baes III (eds.), A Statistical Analysis of Selected Parameter's for Predicting Food Chain Transport and internal Dose of Radionuclides. ORNL/NUREG/TM-282.

2. U.S. Uepartment of Agriculture. 1965. Food and nutrient intake of individuals in the United States, Spring 1:؟5 Household Consumption Survey 1965-65. Report No. 11.

3. Blanchard, R. L. Criteria for the Estimation of Radiation Dose. Inpublished. Data averaged by Blanchard from references $4-7$, this paper.

4. Soldat, J. K. 1976. Radiation doses from iodine-129 in the environment. Healir Phys. 30:61.

5. Essig, T. H., and J. P. Corley. 1969. Criteria Used to Estimate Doses Receined by Persons Living in the Vicinity of Hanjora: Interin Pepont ilo. 2. BNWL-1019.

6. Soldat, J. K. 1976. Reply to J.C. Thompson, Jr.'s comments on the paper, Radiation doses from iodine-129 in the environment, by J. K. Soldat. Heaith Phys. $31: 288$.

7. U.S. Department of Agriculture. 1977. Food Consumption, Prices and Expenditures. Supplement for 1975 to Agriculture Economic Report AER-138. 
74

8. U.S. National Marine Fisheries Service. 1973-74. Unpublished data.

9. Pup, E. M., F. L. Miller, and C. F. Bats III. 1979. Some results by age and region of recent surveys of fish and shellfish consumption by U. S. residents. In preparation.

10. Cook, C. B., 0. A. Filer, and 0.7. Forked. 1975. Beverage consumption patterns in New York state. Afr. Diet. Assess. $6^{7}(3): 222-27$.

11. International Commission Radiological Protection. 1974. Report of the Task Croup on Reference Iron. ICRP Publications 23, Pergamon Press, New York. 
7. DOSE CONVERSION FACTORS

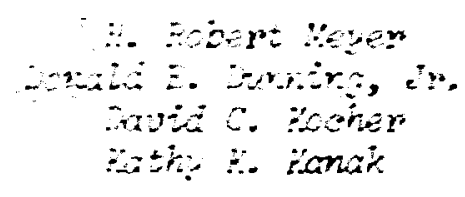

\subsection{Introduction}

The radiological impact to man resulting from operation of a nuclearrelated facility may be assessed by cairulating the dose to individuals and populations residing near the facility. There are a number of potential mojes of exposure to fian from radioactive effluents released to the environment by breeder reactor facilities. Modes contributing to the vast majority of human exposure are inhalation, ingestion, immersion in contaminated air, and exposure to contaminated ground surfaces. Cose conversion factors are used to estimate the dose resulting from these exposures.

\subsection{Internal Dose Conversion Factors}

Table 7.11 ists recomended dose conversion factors for inhalation and ingestion of certain radionuclides determired to be oi potential significance in breeder reactor fuel cycles. These factors are taken from recent:y prepared documents by Killough et al.' and by Dunning et al.,$^{2}$ and were calculated by the use of dosimetric criteria provided by the International Commission on Radiological Protection ${ }^{3}$ and other recognized authorities. These factors are computed with the computer code INREM II, which approximates the solutions of differential equations which motel inidke, translocation and metabolism of a radionuclide and its prorjeny. 


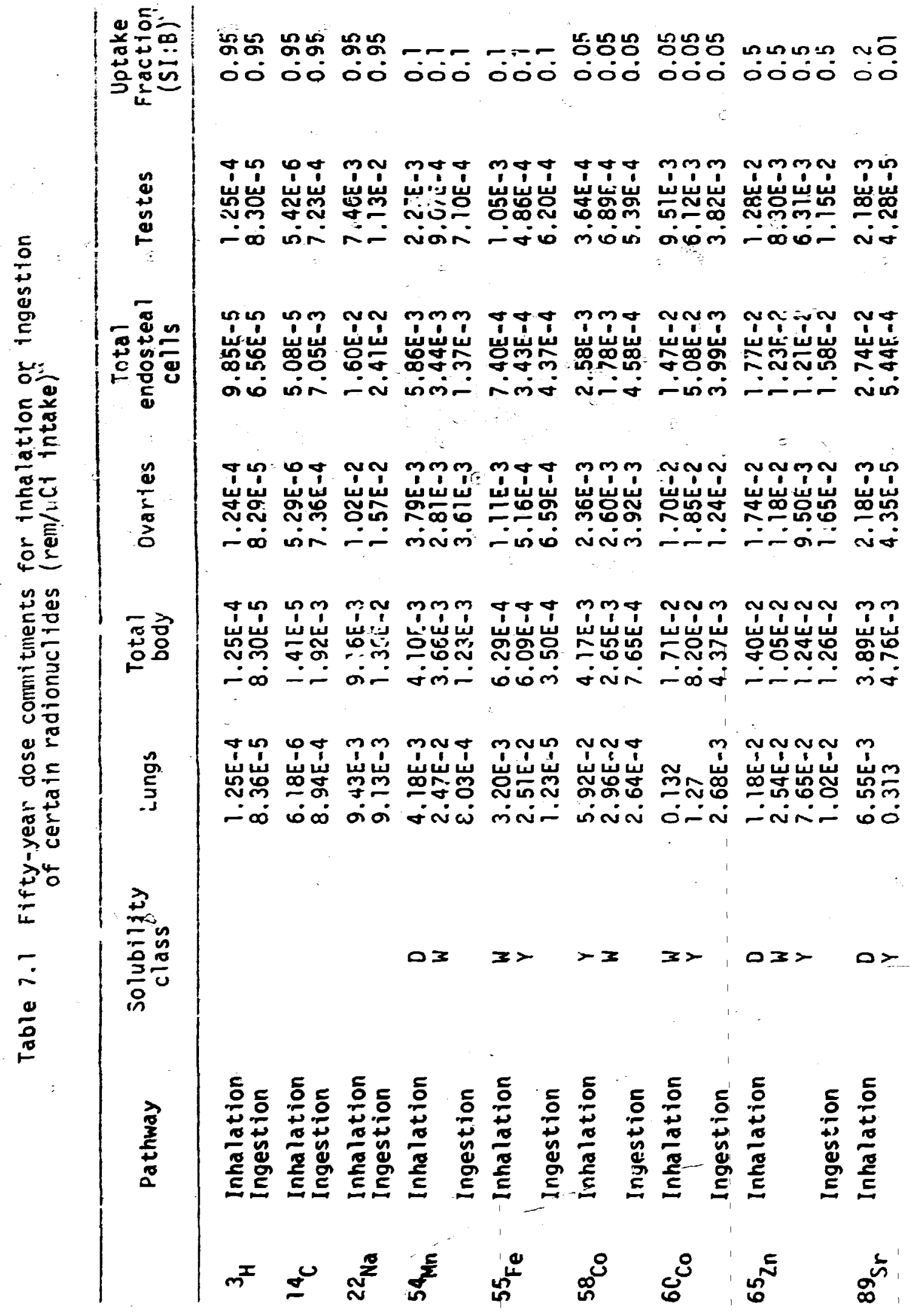




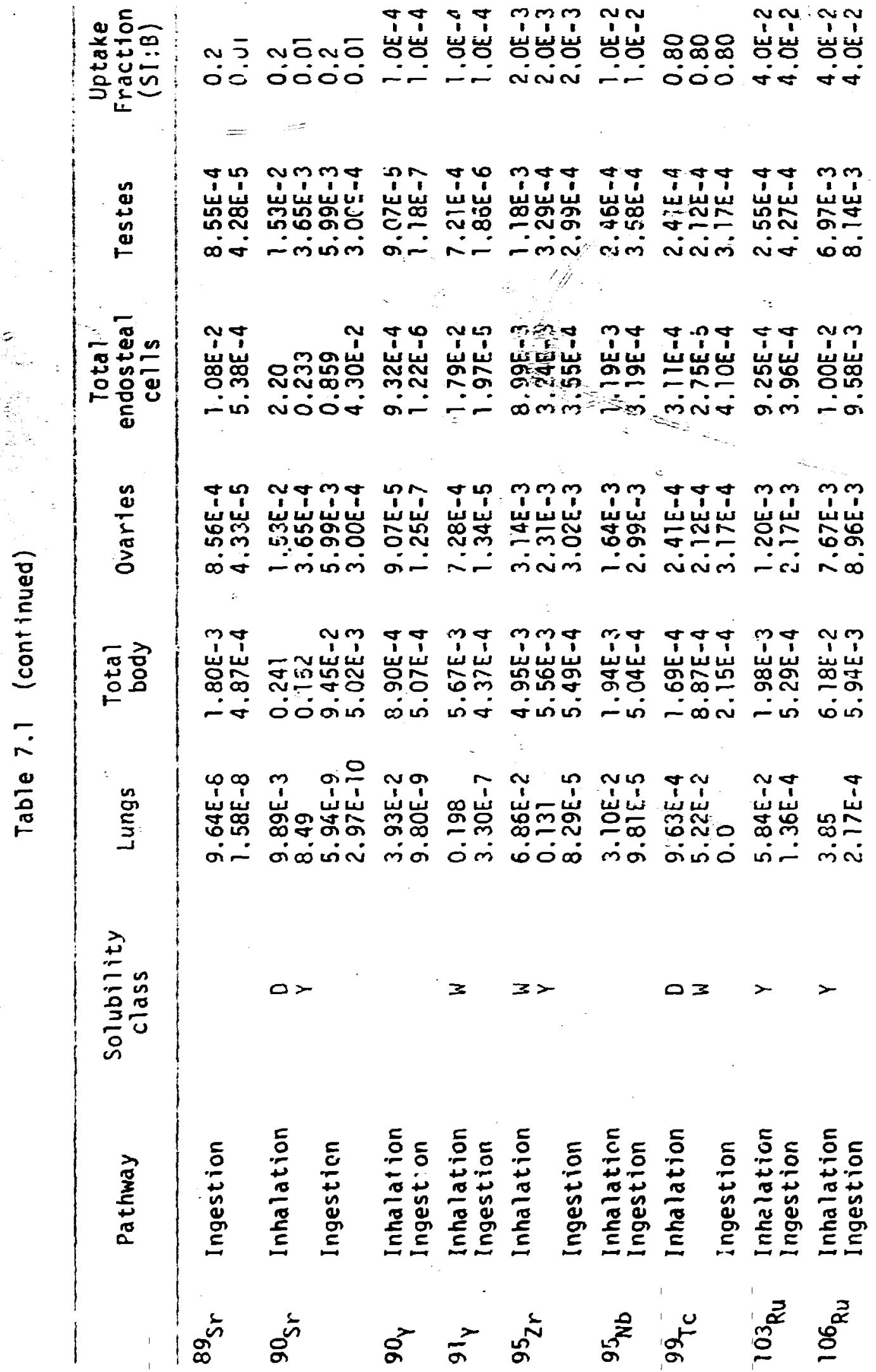




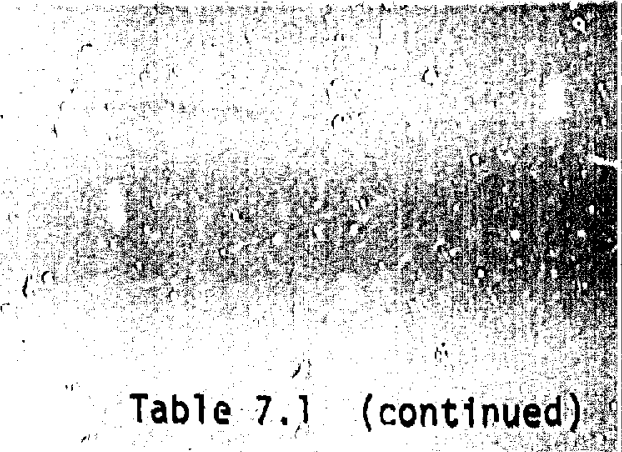

Table 7.1 (continued)

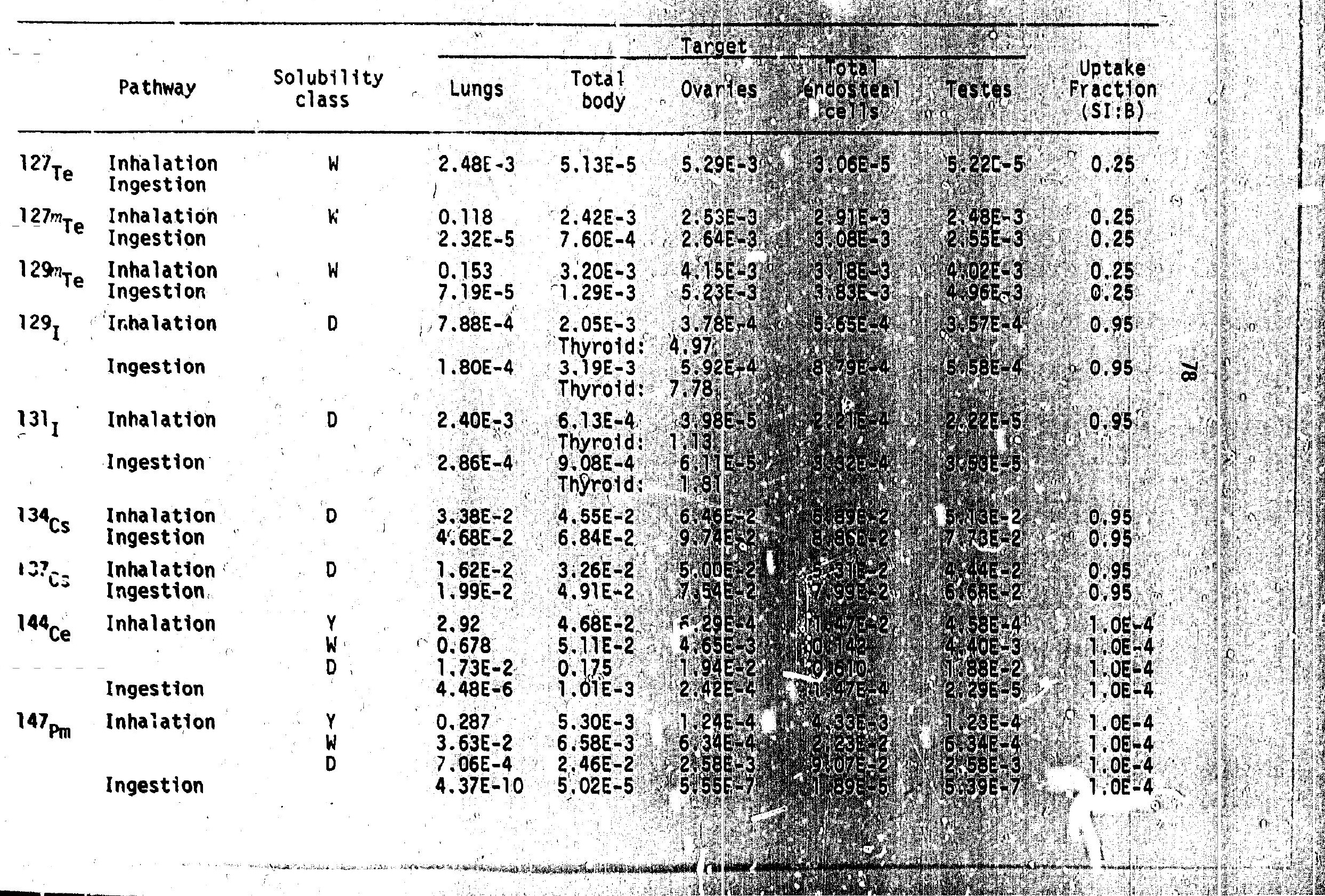




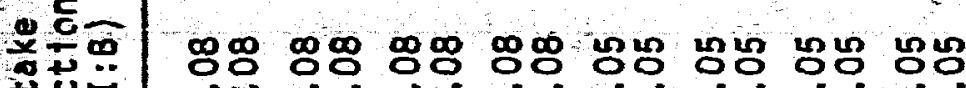

(1)

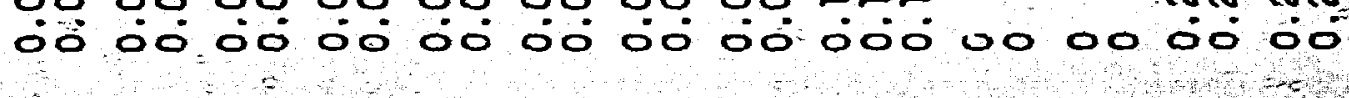

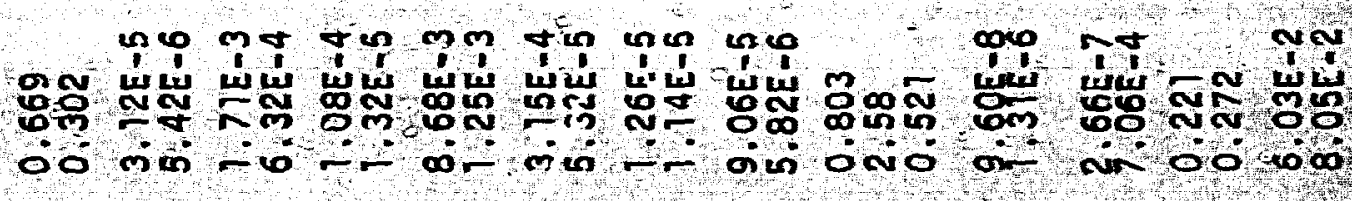

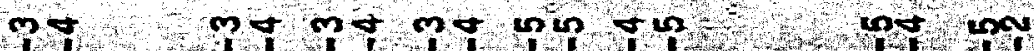

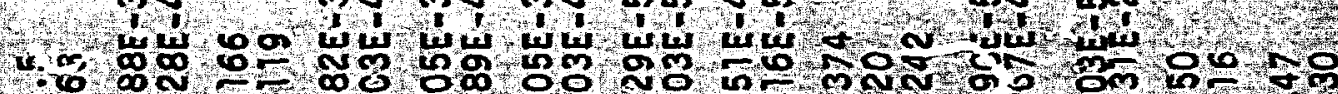

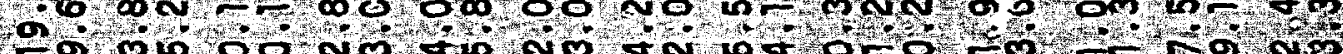

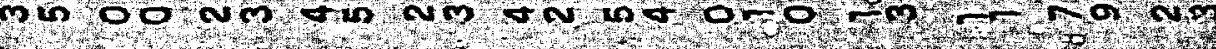

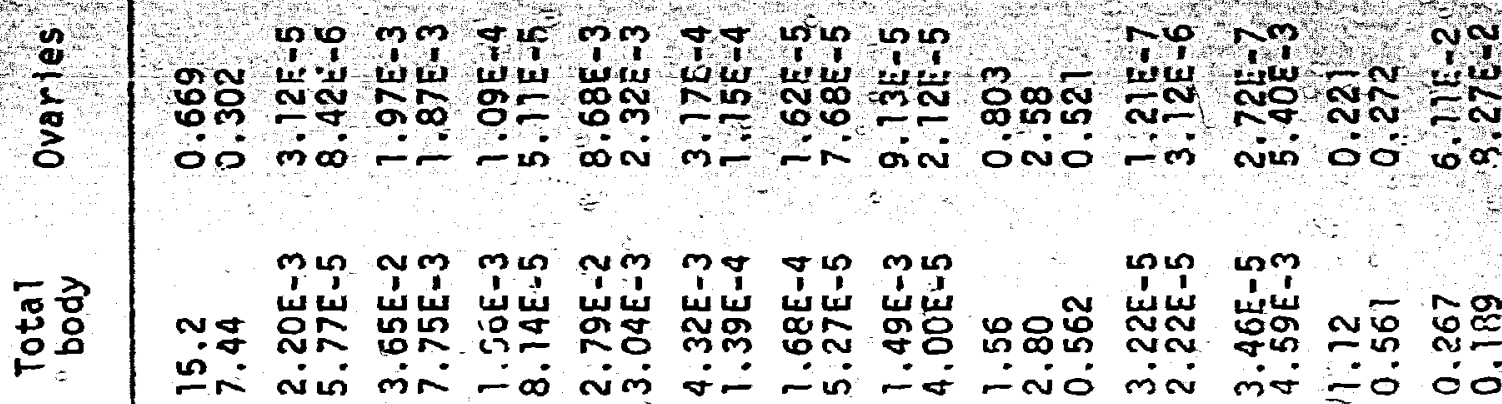

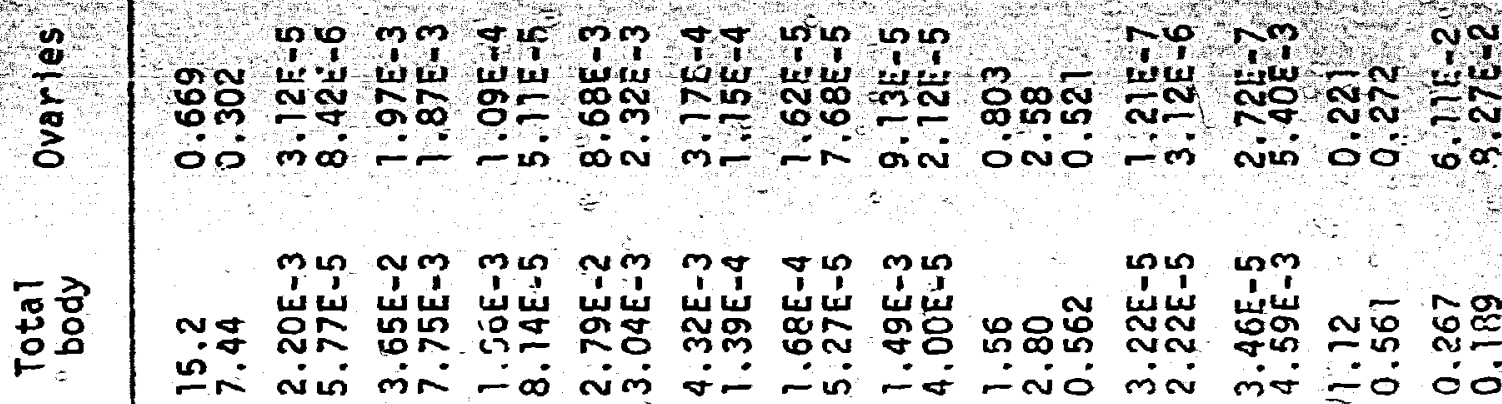

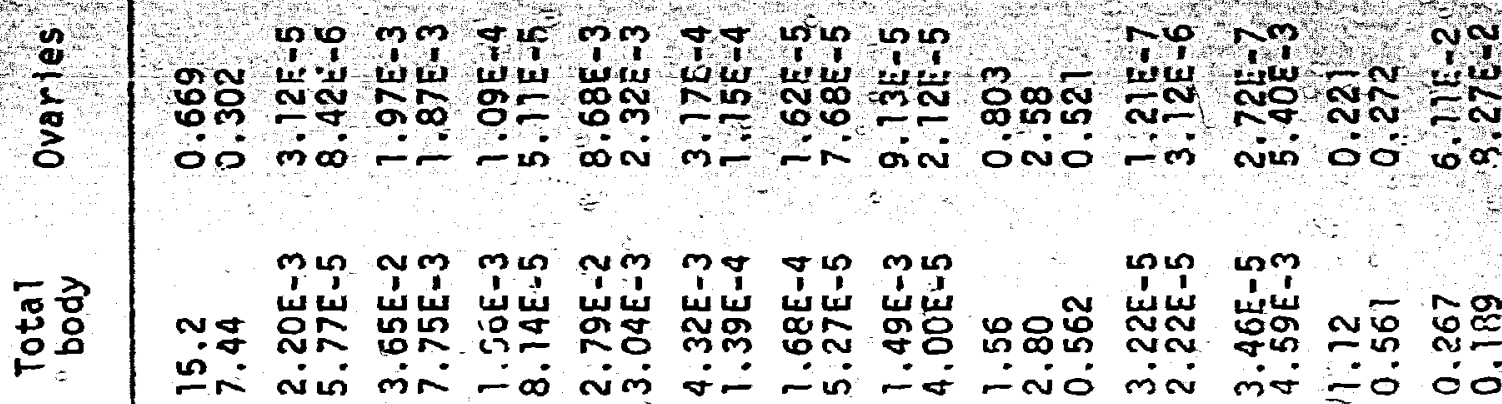

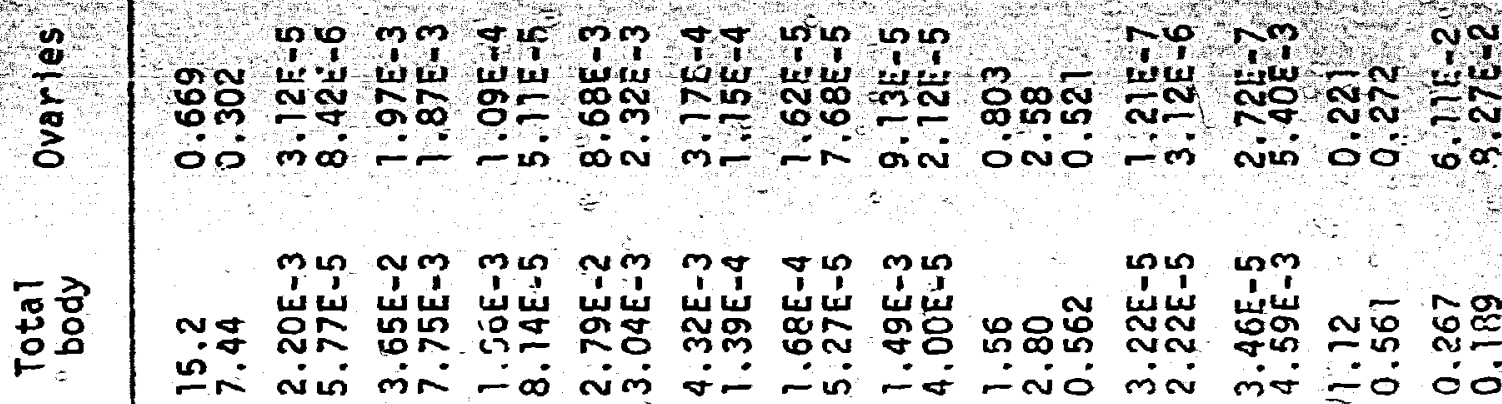

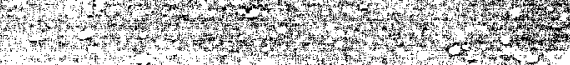

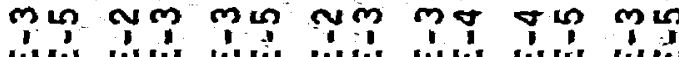

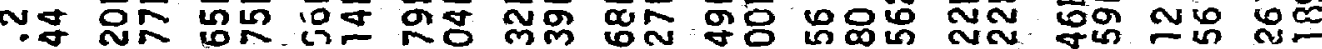

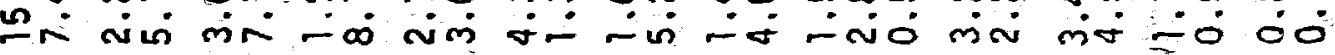

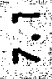

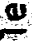

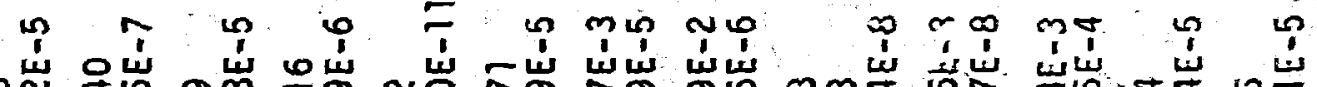

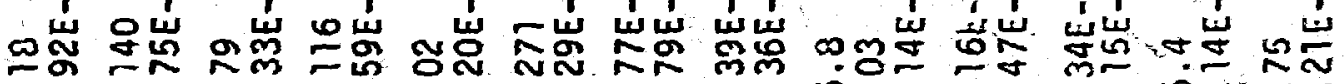
i d do

章

$x=3 x=33230$ 芯

疍

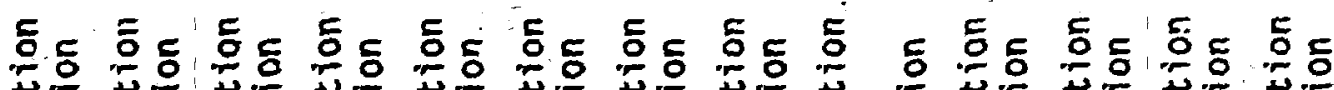

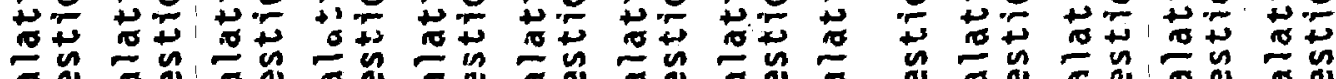

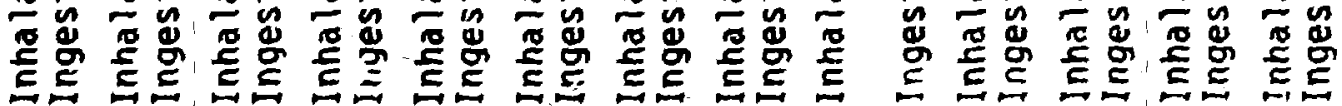

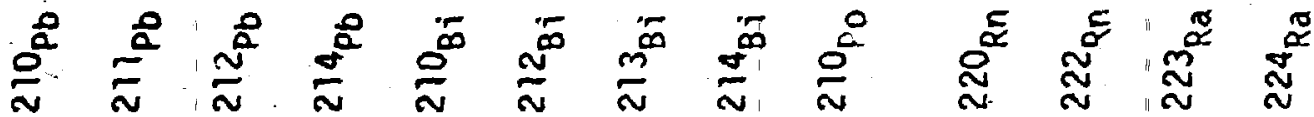


BI

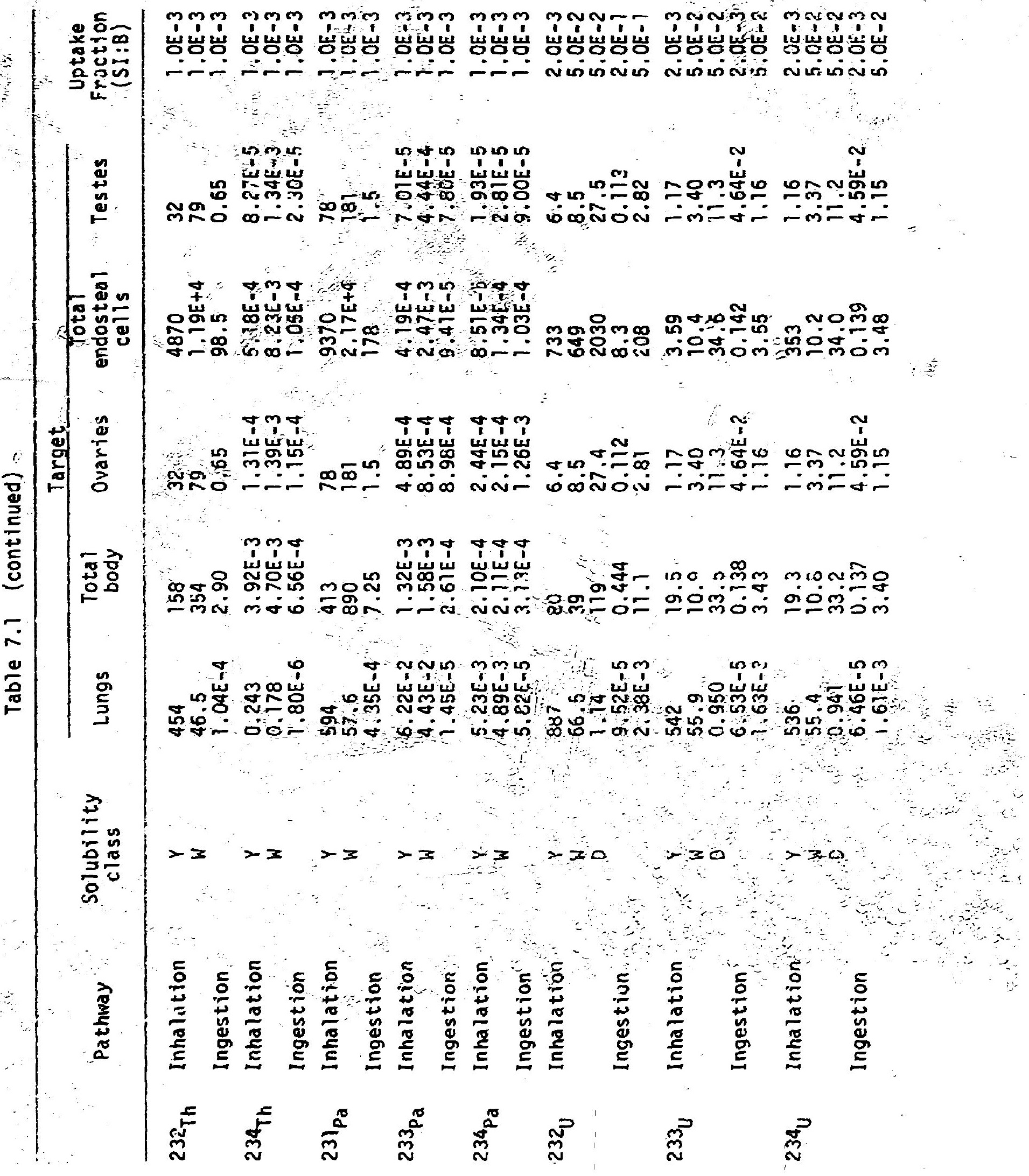




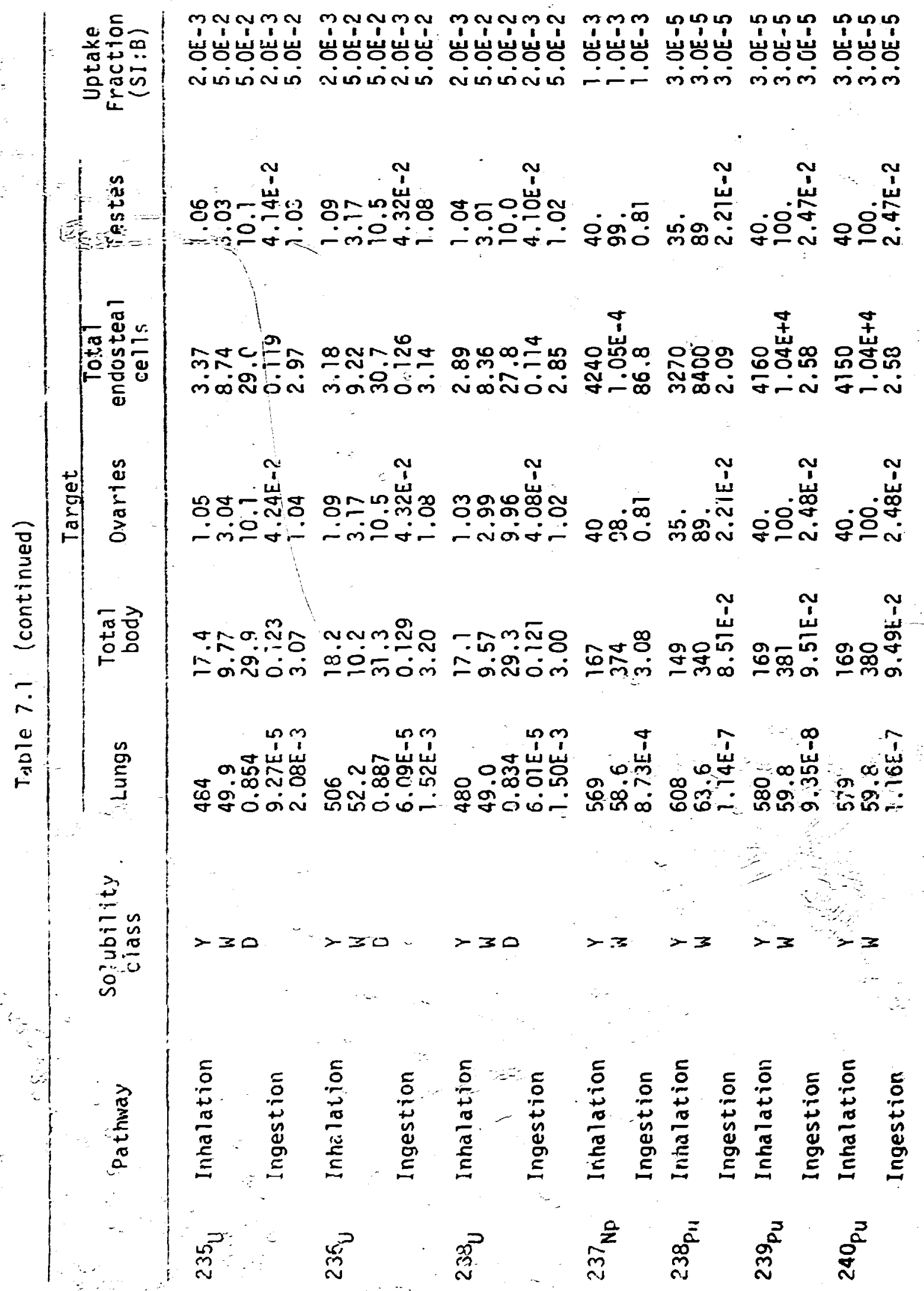


Table 7.1 (continued)

\begin{tabular}{|c|c|c|c|c|c|c|c|c|}
\hline & \multirow[b]{2}{*}{ Pathway } & \multirow[b]{2}{*}{$\begin{array}{l}\text { Solubility } \\
\text { class }\end{array}$} & \multicolumn{5}{|c|}{ Target } & \multirow[b]{2}{*}{$\begin{array}{c}\text { Uptake } \\
\text { Fraction } \\
(S I: B)\end{array}$} \\
\hline & & & Lungs & $\begin{array}{r}\text { Total } \\
\text { body }\end{array}$ & Ovaries & $\begin{array}{l}\text { Total } \\
\text { endosteal } \\
\text { cells }\end{array}$ & Testes & \\
\hline${ }^{241} \mathrm{Pu}$ & $\begin{array}{l}\text { Inhalation } \\
\text { Ingestion }\end{array}$ & $\begin{array}{l}Y \\
W\end{array}$ & $\begin{array}{l}1.10 \\
1.54 E-2 \\
7.18 E-8\end{array}$ & $\begin{array}{l}3.52 \\
7.75 \\
1.93 \mathrm{E}-3\end{array}$ & $\begin{array}{l}9.00 E-1 \\
2.0 \\
5.10 E-4\end{array}$ & $\begin{array}{l}85.4 \\
194^{4} \\
4.83 E-2\end{array}$ & $\begin{array}{l}0.90 \\
2.1 \\
5.11 E-4\end{array}$ & $\begin{array}{l}3 . O E-5 \\
3 . O E-5 \\
3.0 E-5\end{array}$ \\
\hline $242 \mathrm{Pu}$ & $\begin{array}{l}\text { Inhalation } \\
\text { Ingestion }\end{array}$ & $\begin{array}{l}Y \\
W\end{array}$ & $\begin{array}{l}550 \\
56.8 \\
1.91 E-7\end{array}$ & $\begin{array}{l}161 \\
361 \\
9.02 E-2\end{array}$ & $\begin{array}{l}38 \\
95 \\
2.36 E-2\end{array}$ & $\begin{array}{l}4790 \\
1.05 E+4 \\
2.60\end{array}$ & $\begin{array}{l}38 \\
95 \\
2.35 E-2\end{array}$ & $\begin{array}{l}3 . O E-5 \\
3 . O E-5 \\
3 . O E-5\end{array}$ \\
\hline $241_{A m}$ & $\begin{array}{l}\text { Inhalation } \\
\text { Ingestion }\end{array}$ & $\begin{array}{l}Y \\
W\end{array}$ & $\begin{array}{l}615 \\
63.6 \\
1.28 E-4\end{array}$ & $\begin{array}{l}175 \\
392 \\
3.22\end{array}$ & $\begin{array}{l}41 \\
103 \\
0.85\end{array}$ & $\begin{array}{l}3900 \\
9730 \\
80.2\end{array}$ & $\begin{array}{l}41 \\
103 \\
0.85\end{array}$ & $\begin{array}{l}1 . O E-3 \\
1.0 E-3 \\
1.0 E-3\end{array}$ \\
\hline $243_{\mathrm{Am}}$ & $\begin{array}{l}\text { Inhalation. } \\
\text { Ingestion }\end{array}$ & $\begin{array}{l}Y \\
W\end{array}$ & $\begin{array}{l}595 \\
61.4 \\
9.56 E-4\end{array}$ & $\begin{array}{l}175 \\
391 \\
3.21\end{array}$ & $\begin{array}{l}41 \\
10.3 \\
0.85\end{array}$ & $\begin{array}{l}4170 \\
1.03 E+4 \\
85.2\end{array}$ & $\begin{array}{l}42 \\
103 \\
0.85\end{array}$ & $\begin{array}{l}1.0 E-3 \\
1.0 E-3 \\
1.0 E-3\end{array}$ \\
\hline${ }^{242} \mathrm{Cm}$ & $\begin{array}{l}\text { Inhalation } \\
\text { Ingestion }\end{array}$ & $\begin{array}{l}Y \\
W\end{array}$ & $\begin{array}{l}172 \\
54.8 \\
2.65 E-6\end{array}$ & $\begin{array}{l}3.67 \\
8.76 \\
7.34 E-2\end{array}$ & $\begin{array}{l}2.70 E-1 \\
2.0 \\
1.85 E-2\end{array}$ & $\begin{array}{l}22.5 \\
168 \\
1.53\end{array}$ & $\begin{array}{l}0.26 \\
2.0 \\
1.85 E-2\end{array}$ & $\begin{array}{l}1.0 E-3 \\
1.0 E-3 \\
1.0 E-3\end{array}$ \\
\hline${ }^{243} \mathrm{Cn!}$ & $\begin{array}{l}\text { Inhalation } \\
\text { Ingestion }\end{array}$ & $\begin{array}{l}Y \\
W\end{array}$ & $\begin{array}{l}627 \\
67.5 \\
3.26 E-4\end{array}$ & $\begin{array}{l}113 \\
261 \\
2.15\end{array}$ & $\begin{array}{l}25 \\
68 \\
0.17\end{array}$ & $\begin{array}{l}2150 \\
5780 \\
47.8\end{array}$ & $\begin{array}{l}25 \\
68 . \\
0.56\end{array}$ & $\begin{array}{r}1.0 E-3 \\
11.0 E-3 \\
1.0 E-3\end{array}$ \\
\hline${ }^{244} \mathrm{~cm}$ & $\begin{array}{l}\text { Inhalation } \\
\text { Ingestion }\end{array}$ & $\begin{array}{l}Y \\
W\end{array}$ & $\begin{array}{l}607 \\
66.8 \\
3.54 E-6\end{array}$ & $\begin{array}{l}86.5 \\
204 \\
1.68\end{array}$ & $\begin{array}{l}19 . \\
53 . \\
0.44\end{array}$ & $\begin{array}{l}1620 \\
4560 \\
37.7\end{array}$ & $\begin{array}{l}19 . \\
53 . \\
0.43\end{array}$ & $\begin{array}{l}1.0 E-3 \\
1.0 E-3 \\
1.0 E-3\end{array}$ \\
\hline
\end{tabular}

$i_{0}=$ daily, $W=$ weekly, $Y=$ yearly (ref. 3).

$S I: B=$ Gastrointestinal uptake fraction; small intestine: blood (refs", 1,2).

Activity median aerodynamic diameter (AMAD) $=1$ im (ref. 1 ). 
The INREM II computer code utilizes an adaptation of the Task Group Lung Model $^{3}$ to describe radionuclide deposition and retention dynamics within the respiratory tract. A catenary gastrointestional (GI) tract model based on the transit times recommended by $\mathrm{Eve}^{4}$ simulates retention in the GI tract. Retention in other organs is represented by multicompartment sodels consisting of series of decaying exponential terms. Detailed discussion of these models and assumptions is available in references 1 and 2.

In the conte; $t$ of radionuclides released during routine breeder reactor fuel cycle opera.ions, it is useful to consider the calculation of 50-year dose commitments in terms of three radionuclide classes, based on effective half-life of radionuclides in the human hody. Depending on the organ under consideration, one of several approaches will apply.

For radionuclides that have short biological half-times of residence or short radiclogical half-lives, the 50-year dose commitment would be approximately the same as the annual dose. For example, all of the dose commitment for ${ }^{2} \bar{c} J_{R n}$ exposure (including radon daughters) is received during the first year.

For radionuclides of intermediate longevity in humans, dose would be accrued at a declining rat.- over the entire 50-year period, based on models and associated parameters specific to the organ and nuclide of concern. For example, ${ }^{232} \mathrm{U}$ (physical $T_{1 / 2}=71.7$ years) is retained in bone according to the uranium retention function:

$$
R_{\text {(bone) }}(t)=0.90 e^{-0.693 t / 20}+0.10 e^{-0.693 t / 5000}
$$


where $t$ is the time of residence in days. This expression incicares that the illitial component of retained uranium is removed rapidly in biological processes with a half-time of 20 days. The seconu component in the expression contributes the majority of the total 50-year dose commitment from $232 U$, at a rate wich decreases with a half-time of 13.7 years.

For elements which are eliminated very slcwly from the bojdy, such as plutonium, and which possess very long physical half-lives $\left[T_{1 / 2}\right.$ $\left({ }^{239} \mathrm{Pu}\right)=2.4 \times 10^{4}$ years $\left.)\right]$, an individual will continue to accrue dese after intake of the radioisotope at a relatively constant rate for the entire 50-year period of interest. linder such conditions, the approximate dose received during the year after the radionuclide enters the body is obtained by dividing the dose commitment by 50 . Thus, the approximate average annual dose rate is only $1 / 50$ of the dose commitment. If an individual is exposed to effluents for a 20 -year operating life of the plant, his annual dose rate during the twentieth year is about 20 times the annual dose rate from one year of exposure.

These generalized obsersations are approximately correct for the conditions cited. However, a detailed calculation must be made to determine the actual dose received in a given year.

Table 7.1 lists 50-year dose commitments for inhalation and ingestion of those radionuclides of interest in this study. These dose equivalents take into account the contributions of radioactive daughters formed by decay of a parent within the body. Dissimilar migrations of daughter elements are also considered. Where a choice of solubility class exists, 
iased on a choice of the chemical form of a particular released radionuclide, dose conversion factors for all solubility classes applicable are listed. The reader is referred to killough et al., ' Dunning et al. ${ }^{2}$ or Morrow et al. ${ }^{3}$ for detáiled discussions of this sibject. A quality factor of 20 is used for alpha particles, a suggested by the I CRP. 5

While dose conversion factors have been calculated elsewhere for 22 target organs, 1,2 the purposes of this report may be best served by focusing on five organs of major interest from the standpoint of health risk assessment. These organs are lungs, total body, ovaries, testes, and total endosteal cells (sensitive cell layer in bone). Dose conversion factors for lung are calculated as dose to the entire lung; this is commaniy identified as the "smeared lung" dose. Gastrointestinal uptake fractions (small intestine: blood) are listed for radionuclides in the final column of Table 7.1. The reader is referred to killough et 21. 1 and Dunning et a1. ${ }^{2}$ for detailed discussion of this subject

\subsection{External Dose Conversion Factors}

Tables 7.2 and 7.3 list external dose conversion factors for the radionuclides of interest as discussed above. Dose conversion factors for immersion in contaminatea air are ?isted for: (1) $:$ dose rate at the skin surface of an exposed body (body surface), and (2) photon ( $r$ and $x$-ray) dose rate to various body organs (lungs, ovaries, skeleton, testes, and total body). Similarly, dose conversion factors for exposure to radionuclides deposited on contaminated ground surfaces are calculated for body surface and for the five organs, as above. These dose conversion factors are from the report by Kocher. 6 
Taule 7.2 Externat dose conversion factors for 3 imers ion in contaminated air (mill $\mathrm{irgm} / \mathrm{yr} / \mathrm{iC}\left(\mathrm{i} / \mathrm{cm}^{3}\right.$ )

(1) 4

14.

tom

Body surface

Lungs Ovaries skeleton - Jesies

Cotal vody

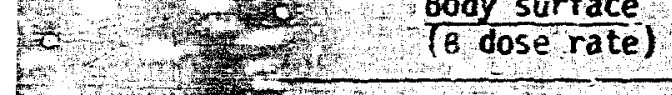

的

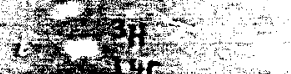

$5.97 E 7$

$4.46 E 8$

$1.74 E 9$

4. $93 \mathrm{Eg}$

4.T4ES

$3.49 E 7$

3. $66 \mathrm{E} 7$

3.01E8

8.64E8

3.97E7

2. $25 \mathrm{EE}$

3.7TE9

$1.82 E 10$

$5.19 E 9$

1.76E9

8.25E9

2.39E8

5. 2 , Eg

$1.04 t 9$

?.9IEE

7.60E8

$6.72 \mathrm{E} 8$

$9.10 E ?$

0.0

0.6

0.0

0.0

0.6

1.17EIO 7.68E9

2. $38 \mathrm{E} 10$

$7.68 E 9$

7.09E9

5. 9669

1.40510

$4.25 \mathrm{Eg}$

2.41Eg

$1.40 E 10$

$6.28 E 3$

$3.35 \mathrm{E} 3$

$797 \mathrm{ES}$

1.37E1O

$2.65 \mathrm{E9}$

3. 5 EEA

$1.12 \mathrm{E} 10$

6.09E9

1-J5E4

$5.593^{2}-101 \mathrm{~F}$

5. 075

2 19E9 356EG

$7.15 E 7+458 E 6$. $1588 E 7$

$1.72 E 10$ TH4E10 $124 \mathrm{EIO}$

$3.70 \mathrm{Eg}$

3.64E9

6. 9605

a.c

4. T9E5

$4.06 \mathrm{Eg}$

$6.89=1$

0.0

E. JiES

$2.72 \mathrm{EO}^{\mathrm{O}}$

3.97EI

0.0

1. $96 E 7$

$1.15 E 9$

3. $75 E 2$

3. $48 E 9$

3. $76 \mathrm{EG}$

$1.53 E 7$

2. $23 E 7$

3. $90 \mathrm{ES}$

0.0

$1.96 \mathrm{Eg}$

4.62E9

2. $41 E 9$

0.0

0.0

4.77E9

0.0

0.0

0.0

$=$

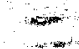

1. I6EIO

0.0

3. 36E?

$9.56 \mathrm{E} 8$

3.1359

2. $31 E 5$

0.0

0.0

1. T6E 10

I.25E10

$6.00 E 9$

1.25E10

4. $35 \mathrm{Eg}$

7.50ES

5. 2 SE

$4.51 E 9$

$5.24 E 9-5: 28 E 9$

$178 E 10$

9.3IF 4

2.82E9

1. $45 E 10$

1. 25E10

$1.06 E 9$

$1.44 E 10$

2.1455

$1.27 E 6$

$1106 \mathrm{Rh}$

$6.01 E 8$

$1.56 \mathrm{EQ}$

5.00E8

$1.33 \mathrm{ES}$

$9.19 \mathrm{ES}$

i. 72610

$1.37 E$

1.27E5

$1.04 \mathrm{E} 10$

$2.14 \mathrm{Eg}$

$54 E$ ?

$1.94 E 8$

7. $.9 \mathrm{Eg}$

$3.25 E 9$

$125 \mathrm{Sb}$

8.79E8

$9.52 \mathrm{ES}$

2.83E9

2. $48 \mathrm{Eg}$

$6 . \overline{92 E 5}$

0.0

4.64E2

3.17EG

1.72EY

$123 E 7$

$2.53 E 7$

$1.92 E 7$

8.39E7

$127^{\mathrm{m}} \mathrm{Te}$. 7.22E8

$6.82 E 6$

$5.24 E 6$

2. $34 E 7$

$127 \mathrm{Te} \quad 2.00 \mathrm{ES}$

2. $48 E 7$

$1.09 E 7$

$3.44 E 7$

$1.55 E 0$

$7.93 E 7$

2.04E\&

$129 \mathrm{Te} \quad 4.85 \mathrm{Eg}$

2. 87.88

1. 35E8

$3.81 E 8$

. $52 E 7$

$1.90 E 7$

7.63E7

131 1.71E9

1. $95 \mathrm{ES}$

$9.03 \mathrm{EZ}$

$2.73 E 9$

3.99ES

4.10E9

5.0

$1.18 E 10$

$1.39 E 8$

$8.20 E 7$

$2.47 E 8$

$133 x e$

$1.22 \mathrm{Eg}$

8.56E7

$3.38 \mathrm{E} 8$

2. $20 \mathrm{ES}$

8.95E8

2. 84 ES

2.90E

0.0

I. $37 E 5$

0.0

5.55E2

2. SIES

2.U7E7

4.00E

$135 \times \mathrm{Xe} \quad 2.82 \mathrm{Eg}$

$1.27 E 9$

$6.87 E 8$

$1.96 \mathrm{Eg}$

$1.67 \mathrm{E} 6$

4. $14 \mathrm{ES}$

$7.69 E 9$

1 1.45Eg

0.0

$4.08 E 9$

$9.83 E 9$

$135 \mathrm{Cs} \quad 1.53 \mathrm{Eg}$

0.0

0.0

0.0

$137^{7 / 5} \mathrm{~B}$

5.67E8

3.04 EG

I. $45 E 5$

3. 79E9

$1.19 E 9$

1. $42 \mathrm{EIO}$

0.0

2.58E9

$0.0^{2}$

1.19E6

1.1359

$1.72 E 8$

1.53 EIO

$2.56 E 9$

.66E8

$7.78 E 7$

2.31Eg

$2.23 \mathrm{ET}$

$5.72 E 2$

$3.13 \mathrm{E} 7$

$.61 E 7$

1.7955

2.69E7

3. 6 . EE

$1.72 \mathrm{ES}$

$6.34 E 7$

$3.12 \mathrm{E} 2$

2. $46 E 9$

$4.85 \mathrm{E} 7$

2.17E8

2.12E9

$1.85 \mathrm{ES}$

$1.69 \mathrm{E}$ ?

$2,62 \mathrm{Eg}$

$1.20 E 8$

$1.74 \mathrm{Eg}$

$2.36 \mathrm{Eg}$

$8.58 E 9$

0.0

8. 4 E

0.7

0.0

$3.35 E 3$

$3.24 E 9$ 
Table 7.2 (continued)

\begin{tabular}{|c|c|c|c|c|c|c|}
\hline & $\frac{\text { Body surface }}{\text { (E dose ratt })}$ & Lungs & $\frac{\text { Ovaries }}{l_{x} \text { and }}$ & $\frac{\text { Skeleton }}{\text {-ray dose } r}$ & $\begin{array}{l}\text { Testes } \\
\text { te) }\end{array}$ & Total body \\
\hline 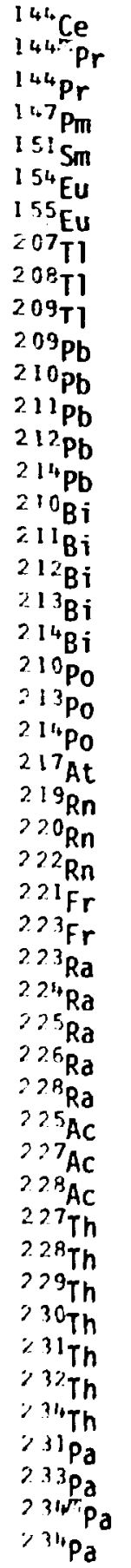 & 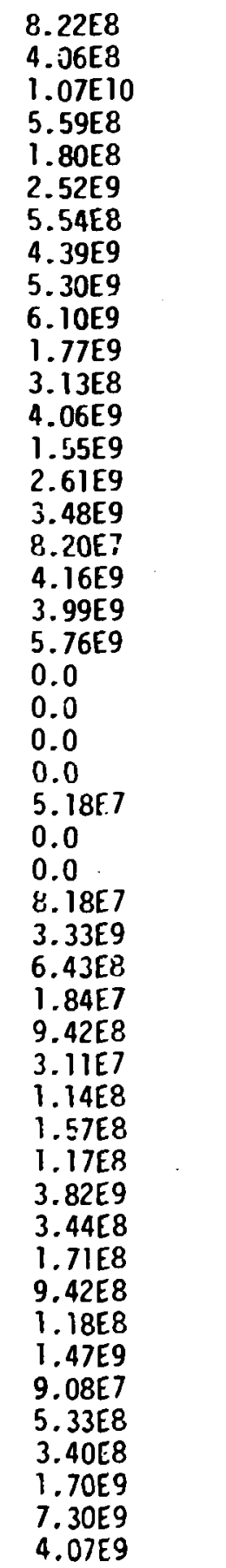 & $\begin{array}{l}8.66 \mathrm{E} 7 \\
1.71 \mathrm{E} 7 \\
1.77 \mathrm{~EB} \\
1.71 \mathrm{E} 4 \\
9.91 \mathrm{E} 2 \\
6.43 \mathrm{E} 9 \\
2.51 \mathrm{E} 8 \\
1.10 \mathrm{E} 7 \\
1.91 \mathrm{E} 10 \\
1.18 \mathrm{E} 10 \\
0.0 \\
4.94 \mathrm{E} 6 \\
2.57 \mathrm{E} 8 \\
7.25 \mathrm{~EB} \\
1.25 \mathrm{E} 9 \\
0.0 \\
2.28 \mathrm{E} 8 \\
9.78 \mathrm{~F} 8 \\
6.79 \mathrm{E} 8 \\
8.28 \mathrm{E} 9 \\
4.33 \mathrm{E} 4 \\
1.55 \mathrm{E} 5 \\
5.58 \mathrm{E} 5 \\
1.52 \mathrm{E} 6 \\
2.85 \mathrm{E} 8 \\
2.82 \mathrm{E} 6 \\
2.00 \mathrm{E} 6 \\
1.56 \mathrm{EE} 8 \\
2.39 \mathrm{E} 8 \\
6.39 \mathrm{E} 8 \\
5.04 \mathrm{E} 7 \\
2.11 \mathrm{E} 7 \\
3.37 \mathrm{E} 7 \\
1.68 \mathrm{E}-2 \\
7.41 \mathrm{E} 7 \\
5.70 \mathrm{E} 5 \\
4.82 \mathrm{E} 9 \\
5.18 \mathrm{E} 8 \\
9.28 \mathrm{E} 6 \\
4.05 \mathrm{E} 8 \\
1.66 \mathrm{EE} 6 \\
6.09 \mathrm{E} 7 \\
6.72 \mathrm{E} 5 \\
3.49 \mathrm{E} 7 \\
1.50 \mathrm{E} 8 \\
9.51 \mathrm{~EB} 8 \\
5.78 \mathrm{E} 7 \\
1.02 \mathrm{E} 10\end{array}$ & 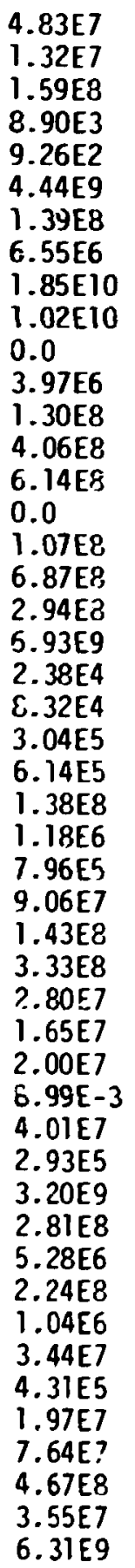 & 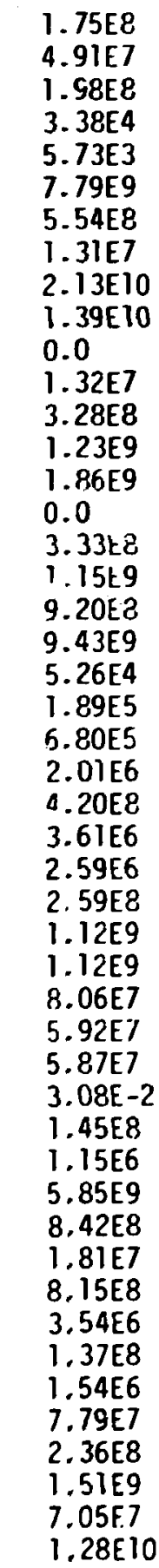 & 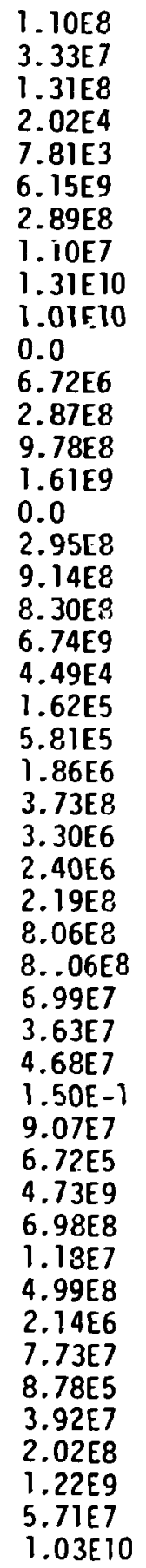 & $\begin{array}{l}1.0 .1 \mathrm{E} \\
2.95 \mathrm{E} 7 \\
1.85 \mathrm{E8} \\
1.98 \mathrm{E} 4 \\
5.62 \mathrm{E} 3 \\
5.85 \mathrm{E} 9 \\
3.09 \mathrm{E} 8 \\
1.16 \mathrm{E} 7 \\
2.02 \mathrm{E} 10 \\
1.25 \mathrm{E} 10 \\
0.0 \\
7.56 \mathrm{E} 6 \\
2.75 \mathrm{E} 8 \\
8.22 \mathrm{E} 8 \\
1.37 \mathrm{E} 9 \\
0.0 \\
2.50 \mathrm{E} 8 \\
1.04 \mathrm{E} 9 \\
7.33 \mathrm{E} 8 \\
8.73 \mathrm{E} 9 \\
4.60 \mathrm{E} 4 \\
1.64 \mathrm{E} 5 \\
5.93 \mathrm{E} 5 \\
1.64 \mathrm{E} 6 \\
3.12 \mathrm{E} 8 \\
3.02 \mathrm{E} 5 \\
2.14 \mathrm{E} 6 \\
1.75 \mathrm{EE} 8 \\
7.29 \mathrm{E} 8 \\
7.29 \mathrm{EE} 8 \\
5.61 \mathrm{E} 7 \\
3.49 \mathrm{E} 7 \\
3.82 \mathrm{E} 7 \\
2.04 \mathrm{E}-1 \\
8.65 \mathrm{E} 7 \\
6.72 \mathrm{E} 5 \\
5.12 \mathrm{E} 9 \\
5.28 \mathrm{EE} 8 \\
1.11 \mathrm{E} 7 \\
4.81 \mathrm{E} 8 \\
2.18 \mathrm{EE} 6 \\
8.00 \mathrm{E} 7 \\
9.85 \mathrm{E} 5 \\
4.32 \mathrm{E} 7 \\
1.69 \mathrm{E} 8 \\
1.06 \mathrm{E} 9 \\
6.15 \mathrm{E} 7 \\
1.09 \mathrm{E} 10\end{array}$ \\
\hline
\end{tabular}




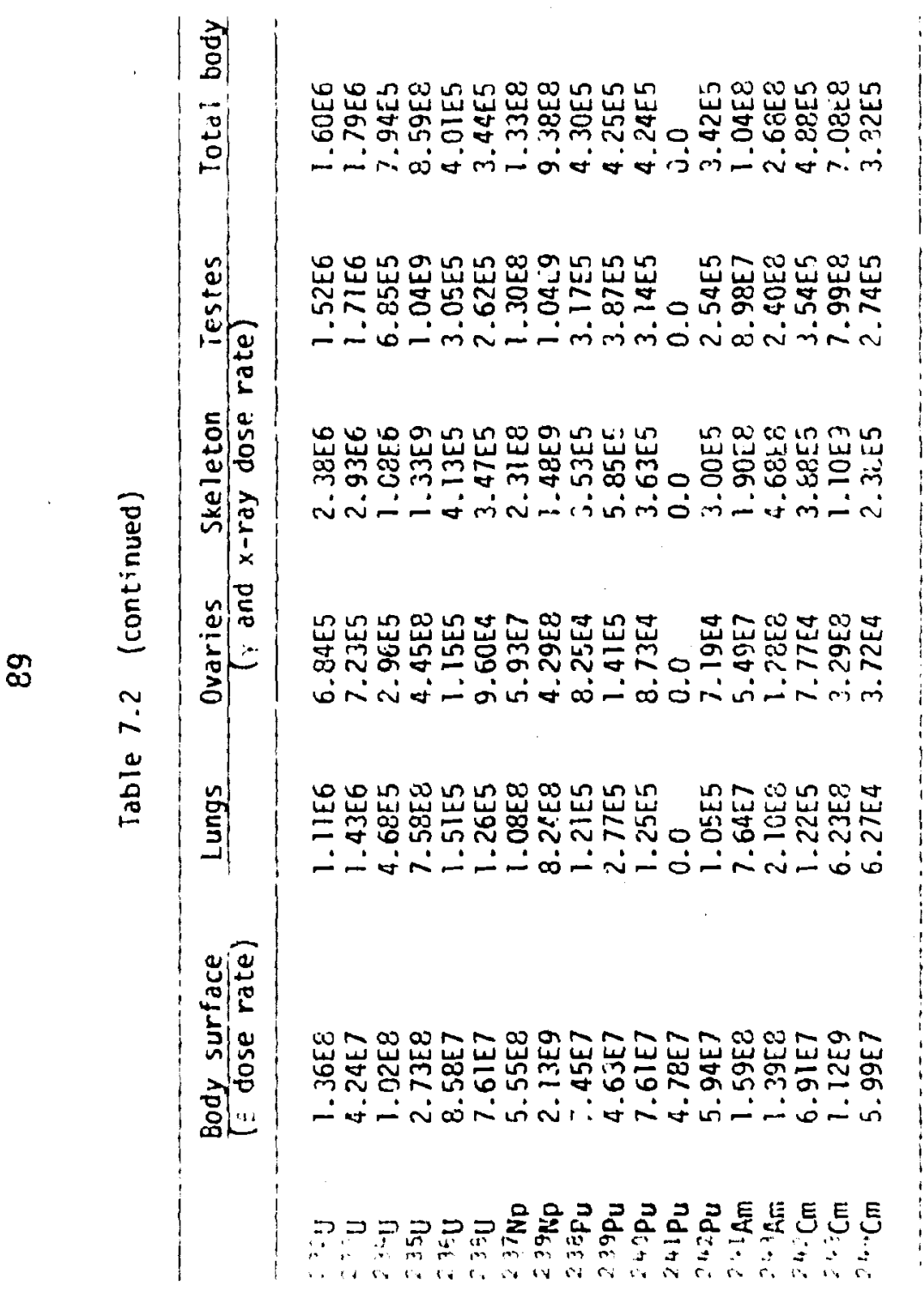


Table ?.3 External dose conversion factors for exposyre to crntaminated ground surface (milli rem/year/: $\mathrm{Ci} / \mathrm{Cm}$ )

\begin{tabular}{|c|c|c|c|c|c|c|}
\hline & $\frac{\text { Body surface }}{T: \text { dose rate) }}$ & Lungs & $\frac{\text { Ovaries }}{\text { li and }}$ & $\frac{\text { Skeleton }}{x \text {-ray dose }}$ & $\begin{array}{l}\text { Testes } \\
\text { rate) }\end{array}$ & Total body \\
\hline$H$ & 0.0 & 0.0 & 00 & 0.0 & 0.0 & 0.0 \\
\hline${ }^{4} \mathrm{C}$ & 0.0 & 0.0 & 0.0 & 0.0 & 0.0 & 0.0 \\
\hline$\therefore$ Nla & $2.22 E 5$ & $2.20 \mathrm{E} 6$ & 1.4056 & $2.64 E 6$ & 2.21E6 & $2.33 E 6$ \\
\hline$\therefore \boldsymbol{M a}$ & $7.87 E 6$ & $3.56 E 6$ & $3.63 \mathrm{E} 6$ & $3.87 \mathrm{E} 6$ & $2.38 \mathrm{E} 6$ & $3.76 E 6$ \\
\hline$\therefore$ ! Ar & $6.00 E 6$ & $1.23 E 6$ & $1.34 E 6$ & 1. $39 \mathrm{E} 6$ & $1.04 E 6$ & 1.30E6 \\
\hline$=r_{+} M_{r i}$ & 0.0 & $8.19 E 5$ & $4.63 E 5$ & G.89E5 & $8.37 E 5$ & $8.69 E 5$ \\
\hline$\therefore \mathrm{Fe}$ & 0.0 & 1. 1 & $6.33 E 9$ & $2.17 \mathrm{El}$ & $1.05 \mathrm{E2}$ & I. $44 \mathrm{E2}$ \\
\hline$\because \mathrm{Co}$ & $8.52 E 3$ & $9.70 E 5$ & $5.16 E 5$ & $1.19 E 6$ & $1.03 \mathrm{E} 6$ & $1.03 \mathrm{E} 6$ \\
\hline$\therefore \mathrm{CO}$ & $6.68 E 3$ & $2.40 E 6$ & $1.96 \mathrm{E} 6$ & $2.72 \mathrm{E} 6$ & 2. D7E6 & $2.54 F 6$ \\
\hline $3 \mathrm{Ni}$ & 0.0 & $2.23 E ?$ & ?. I9EI & $4.07 \mathrm{El}$ & $1.98 E 2$ & $\therefore 7 i 22$ \\
\hline$\therefore \mathrm{Zn}$ & $6.01 E-4$ & $5.56 \mathrm{E} 5$ & $3.96 \mathrm{E} 5$ & $6.44 E 5$ & $5.12 E 5$ & $5.88 E 5$ \\
\hline$\because \mathrm{Kr}$ & $1.25 E 6$ & $2.36 E 3$ & $9.42 \mathrm{E} 2$ & $3.05 E 3$ & $2.83 E 3$ & $2.53 \mathrm{E} 3$ \\
\hline$K r$ & 2. $94 E 6$ & $1.76 E 6$ & $1.76 E 6$ & $1.95 E 6$ & $1.13 \mathrm{E} 6$ & $1.84 E 6$ \\
\hline$\because \mathrm{Rb}$ & $1.95 E ?$ & $5.96 E 5$ & $5.76 E 5$ & 6.5655 & $4.07 E 5$ & $6.24 E 5$ \\
\hline$=35 r$ & $8.57 E 6$ & $1.32 E 2$ & $7.92 \mathrm{EI}$ & I.57E & i. 3IE2 & $1.40 E 2$ \\
\hline$\because s r$ & $2.74 E 5$ & 0.0 & 0.0 & $0 . n$ & 0.0 & 0.0 \\
\hline$\because y$ & 1.3:EI & $.19 E-1$ & $6.73 E-2$ & $6.44 E-1$ & $7.92 E-1$ & $9.65 \bar{c}-1$ \\
\hline$\because 1^{-}$ & $4.41 E 5$ & $5.54 E 5$ & $2.35 E 5$ & $7.09 E 5$ & $6.46 E 5$ & $5.93 E 5$ \\
\hline$\because ! \gamma$ & $3.88 E 6$ & $3.46 \mathrm{E} 3$ & $2.71 E 3$ & $3.95 E 3$ & $3.04 E 3$ & $3.66 \mathrm{E} 3$ \\
\hline$\because \mathrm{Zr}$ & $2.29 E 4$ & $7.38 \mathrm{ES}$ & $3.84 F 5$ & $9.06 E 5$ & 7. RASE & $7.84 F .5$ \\
\hline$\because A b$ & 0.0 & $7.61 F 5$ & $4.05 E 5$ & $9.31 E 5$ & $8.01 E 5$ & $8 . .9955$ \\
\hline TC & 0.0 & 0.0 & 0.0 & $0 . c$ & 0.0 & 0.0 \\
\hline$\therefore R u$ & $2.98 E 4$ & $4.97 E 5$ & $1.97 E 5$ & $6.4 \div \times 5$ & $5.98 E 5$ & $5.32 E \overline{5}$ \\
\hline $10 . \mathrm{Bu}$ & 0.0 & 0.0 & 0.0 & 0.0 & 0.0 & 0.0 \\
\hline $1 \% \mathrm{Rh}$ & 0.0 & 2. $32 E 2$ & $2.22 t ?$ & $1.41 E 3$ & $1.94 E 3$ & $1.36 E 3$ \\
\hline lor.gh & i. . 70E 7 & 2.11E5 & $9.87 E 4$ & $2.66 E 5$ & $2.39 E 5$ & $2.25 E 5$ \\
\hline $1 ! 7,9$ & $3.39 E 4$ & $2.71 \mathrm{E} 6$ & $1.7 \cap \mathrm{E} 6$ & $3.24 E 6$ & $2.70 E 6$ & $2.88 \mathrm{E} 6$ \\
\hline $11 \mathrm{Ag}$ & $1.54 E 7$ & 3. $10 E 4$ & $1.50 \mathrm{E} 4$ & $3.87 E 4$ & $3.42 \mathrm{~F} 4$ & 3. 2iE4 \\
\hline $1: 5 b$ & $1.05 E 5$ & $4.42 E 5$ & $1.98 E 5$ & $5.91 E 5$ & $5.34 E 5$ & $4.80 E 5$ \\
\hline $125^{\circ} \mathrm{Te}$ & 0.0 & $1.11 E 4$ & $8.45 E^{\prime}$ & $3.68 E 4$ & $3.42 E 4$ & $2.50 E 4$ \\
\hline $1 . \mathrm{Ta}$ & $3.66 \mathrm{E} 4$ & $3.10 E 3$ & $2.37 \mathrm{E} 3$ & $1.05 \mathrm{E} 4$ & $9.96 E 3$ & $7.21 E 3$ \\
\hline $12 \%$ & $8.24 E 5$ & $5.25 E 3$ & $2.30 \mathrm{E} 3$ & $7.28 E 3$ & $6.62 E 3$ & $5.69 E 3$ \\
\hline $1.9^{\circ} \mathrm{Te}$ & $3.05 E 6$ & $3.20 \mathrm{E} 4$ & $1.67 \mathrm{E} 4$ & $4.48 E 4$ & $3.97 \mathrm{E} 4$ & $3.71 E 4$ \\
\hline :Te & $7.22 \mathrm{E} 6$ & $5.90 E 4$ & $2.77 E 4$ & $7.98 E 4$ & $724 E 4$ & $6.50 \mathrm{E} 4$ \\
\hline $1: 3$ & 0.0 & $1.32 E 4$ & $9.89 E 3$ & $4.02 E 4$ & $3.41 E 4$ & $2.57 \mathrm{E} 4$ \\
\hline $13 ! 1$ & $3.25 E 5$ & $4.12 E 5$ & $1.91 E 5$ & $5.78 E 5$ & $5.22 E 5$ & $4.49 E 5$ \\
\hline$: 33 \times \mathrm{xe}$ & 0.0 & $3.58 E 4$ & $2.19 E 4$ & $7.05 E 4$ & $6.23 \mathrm{E} 4$ & $4.77 E 4$ \\
\hline $1.3 \mathrm{Xe}$ & $1.56 E 0$ & 4.01E4 & $2.45 E 4$ & $3.70 E 4$ & $5.79 E 4$ & $5.57 E 4$ \\
\hline $135 \mathrm{xe}$ & 1. $31 E 6$ & $4.53 E 5$ & $1.85 E 5$ & $5.87 E 5$ & $5.41 E 5$ & $4.87 E 5$ \\
\hline $135 \times \mathrm{Xe}$ & $2.48 \mathrm{E} 6$ & $2.74 E 5$ & $1.49 E 5$ & $4.25 E 5$ & $3.77 E 5$ & $3.04 E 5$ \\
\hline $131+\mathrm{Cs}$ & $5.17 E 5$ & $1.57 E 6$ & $7.99 E 5$ & $1.94 E 6$ & $1.69 E 6$ & $1.67 \mathrm{EE}$ \\
\hline $17 \mathrm{Cs}$ & 0.0 & 0.0 & 0.0 & 0.0 & 0.0 & 0.0 \\
\hline $1: C_{s}$ & $3.99 E 5$ & 0.0 & 0.0 & 0.0 & 0.0 & 0.0 \\
\hline $1 \div 7^{r} \mathrm{Ba}$ & 1.1956 & $6.06 E 5$ & $2.91 E 5$ & $7.59 E 5$ & $6.70 E 5$ & $6.47 E 5$ \\
\hline $1 " 4 \mathrm{Ce}$ & 0.5 & $2.04 E 4$ & $1.16 E !$ & $4.19 E 4$ & $2.65 E 4$ & $2.50 E 4$ \\
\hline $11,1, \mathrm{Pr}$ & 0.0 & $6.47 E 3$ & $4.98 E 3$ & $1.35 E 4$ & $1.26 E 4$ & $1.12 E 4$ \\
\hline$\|_{0} \omega_{\mathrm{pr}}$ & $1.5 \mathrm{jE} 7$ & $2.94 E 4$ & $2.55 \mathrm{E} 4$ & $3.34 E 4$ & $2.27 E 4$ & $3.10 E 4$ \\
\hline
\end{tabular}


Table 7.3 (continued)

\begin{tabular}{|c|c|c|c|c|c|c|}
\hline & $\frac{\text { Body surface }}{(E \text { dose rate) }}$ & Lungs & $\frac{\text { Ovaries }}{\text { Tr and }}$ & $\frac{\text { Skeleton }}{x \text {-ray dose }}$ & $\frac{\text { Testes }}{\text { rate) }}$ & Total body \\
\hline $147 \mathrm{Pm}_{\mathrm{m}}$ & 0.0 & $3.82 \mathrm{EO}$ & $2.00 \mathrm{EO}$ & $7.57 \mathrm{EO}$ & $4.54 E 0$ & $4.43 \mathrm{E} 0$ \\
\hline $151 \mathrm{Sm}$ & 0.0 & $1.08 E O$ & $9.98 E-1$ & $6.14 E 0$ & $8.50 E 0$ & $6.24 \mathrm{EO}$ \\
\hline $154 \mathrm{Eu}$ & $1.77 E 6$ & $1.20 E 6$ & $8.15 E 5$ & $1.47 E 6$ & $1.15 \mathrm{E} 6$ & $1.28 E 6$ \\
\hline $155 \mathrm{Eu}$ & 0.0 & $6.13 E 4$ & $3.50 E 4$ & $1.38 E 5$ & $7.22 \mathrm{E} 4$ & $7.73 \mathrm{E} 4$ \\
\hline $207 \mathrm{TI}$ & $6.69 \mathrm{E} 6$ & $2.09 E 3$ & $1.24 \mathrm{E} 3$ & $2.49 E 3$ & $2.08 \mathrm{E} 3$ & $2.21 E 3$ \\
\hline $208 \mathrm{Tl}$ & 8.10E6 & $2.94 E 6$ & $2.72 \mathrm{E6}$ & $3.32 E 6$ & $2.13 E 6$ & $3.11 E 6$ \\
\hline $209 \mathrm{TI}$ & $9.62 \mathrm{E} 6$ & $2.08 E 6$ & $1.74 E 6$ & $2.49 \mathrm{E} 6$ & $1.82 E 6$ & $2.22 \mathrm{E} 6$ \\
\hline $209 \mathrm{pb}$ & $4.80 \mathrm{E} 5$ & 0.0 & 0.0 & 0.0 & 0.0 & 0.0 \\
\hline$\approx 10 \mathrm{~Pb}$ & 0.0 & $1.66 E 3$ & $1.32 \mathrm{E} 3$ & $4.42 E 3$ & $2.62 E 3$ & $3.05 E 3$ \\
\hline $2 ! \mathrm{Pb}$ & $5.90 E 6$ & $5.14 \mathrm{E} 4$ & $2.59 E 4$ & $6.60 E 4$ & $5.77 \mathrm{E} 4$ & $5.51 E 4$ \\
\hline $212 \mathrm{~Pb}$ & $2.01 E 4$ & $1.61 E 5$ & $9.02 E 4$ & $2.75 \mathrm{ES}$ & $2.16 \mathrm{ES}$ & $i .83 E 5$ \\
\hline $214 \mathrm{~Pb}$ & $9.16 E 5$ & $2.68 E 5$ & $1.32 E 5$ & $4.02 E 5$ & $3.45 \mathrm{E} 5$ & $2.96 E 5$ \\
\hline $2: C_{B i}$ & $4.51 E 6$ & 0.0 & 0.0 & 0.0 & 0.0 & C. 0 \\
\hline $21 \mathrm{IBi}$ & $6.53 \mathrm{E} 2$ & $4.90 E 4$ & $2.30 \mathrm{E4}$ & $7.15 E 4$ & $6.32 E 4$ & $5.37 E 4$ \\
\hline $2 ! 2 B i$ & $6.37 E 6$ & $1.80 \mathrm{E} 5$ & $1.23 \mathrm{E} 5$ & $2.14 E 5$ & $1.71 \mathrm{E} 5$ & $1.92 \mathrm{E5}$ \\
\hline $21: \mathrm{Bi}$ & $5.36 E 6$ & $1.42 E 5$ & $6.14 E 4$ & $1.93 \mathrm{ES}$ & $1.74 \mathrm{ES}$ & $1.53 E 5$ \\
\hline $214 \mathrm{Bi}$ & $8.50 E 6$ & $1.44 \mathrm{E} 6$ & $1.17 \mathrm{E} 6$ & $1.65 E 6$ & $1.20 E 6$ & $1.51 E 6$ \\
\hline $210 \mathrm{PO}$ & 0.0 & $8.40 E 0$ & $4.62 E 0$ & $1.02 \mathrm{El}$ & $8.70 \mathrm{EO}$ & $8.92 \mathrm{EO}$ \\
\hline $213 \mathrm{PO}$ & 0.0 & $3.01 \mathrm{El}$ & $10.2 \mathrm{El}$ & $3.68 E 1$ & $3.15 \mathrm{EI}$ & $3.20 \mathrm{EI}$ \\
\hline $21+P G$ & 0.0 & $1.08 E 2$ & $\cdot 5.91 \mathrm{El}$ & $1.32 \mathrm{E} 2$ & $1.13 \mathrm{E} 2$ & $1.15 E_{e}$ \\
\hline $217 \mathrm{At}$ & 0.0 & $3.17 \mathrm{E} 2$ & $1.28 \mathrm{E} 2$ & $4.18 \mathrm{E} 2$ & $3.88 E 2$ & $3.41 E 2$ \\
\hline $21: R n$ & $5.46 \mathrm{E} 2$ & $6.11 \mathrm{E} 4$ & $2.96 \mathrm{E} 4$ & $9.02 E 4$ & $8.00 \mathrm{E} 4$ & $6.71 E 4$ \\
\hline$\therefore 2 \mathrm{Rn}$ & 0.0 & $5.76 \mathrm{E} 2$ & $2.41 \mathrm{E} 2$ & $7.38 \mathrm{E} 2$ & $6.75 \mathrm{E2}$ & $6.16 E 2$ \\
\hline $221 \mathrm{Fr}$ & 0.0 & $3.42 \mathrm{E} 4$ & $1.99 E 4$ & $5.70 E 4$ & $4.80 E 4$ & $3.85 \mathrm{E} 4$ \\
\hline $223^{3} \mathrm{Fr}$ & $3.53 \mathrm{E} 6$ & $5.91 \mathrm{E} 4$ & $3.69 \mathrm{E} 4$ & $1.20 \mathrm{ES}$ & $7.30 \mathrm{E} 4$ & $7.39 F 4$ \\
\hline $22: \mathrm{Ra}$ & $2.74 \mathrm{E}\}$ & $1.43 \mathrm{E} 5$ & $7.47 E 4$ & $2.53 \mathrm{E5}$ & $1.80 \mathrm{ES}$ & $1.64 E 5$ \\
\hline$=24 \mathrm{Ra}$ & 0.6 & 1.0 E 4 & $6.11 \mathrm{E} 3$ & $1.76 E 4$ & $1.52 \mathrm{E} 4$ & $1.22 E 4$ \\
\hline $2 \therefore S R a$ & 7.0350 & $8.94 \mathrm{E} 3$ & $6.96 \mathrm{E} 3$ & $2.51 E 4$ & $1.57 \mathrm{E} 4$ & $1.53 \mathrm{E} 4$ \\
\hline $2.5 \mathrm{Ra}$ & 0.0 & $7.43 \mathrm{E} 3$ & $4.41 E 3$ & $1.30 \mathrm{E} 4$ & $1.03 E 4$ & $8.45 \mathrm{E} 3$ \\
\hline $2: E R$ & 0.0 & $3.45 E-5$ & $1.84 t-5$ & $6.31 E-5$ & $3.07 E-4$ & 4. $19 E-4$ \\
\hline$\because \triangle A C$ & 0.0 & $1.70 \mathrm{E} 4$ & $9.17 E_{3}$ & $3.34 \mathrm{E} 4$ & $2.11 E 4$ & $2.04 E 4$ \\
\hline$\because \because 7 \mathrm{AC}$ & 0.0 & 1.3!E2 & $6.75 \mathrm{El}$ & $2.69 \mathrm{E} 2$ & $1.70 \mathrm{OE} 2$ & $1.77 \mathrm{E} 2$ \\
\hline $22 \% \mathrm{AC}$ & $4.15 E 6$ & $9.04 E 5$ & $5.90 \mathrm{E} 5$ & $1.11 \mathrm{E} 6$ & $9.00 E 5$ & $9.64 E 5$ \\
\hline$\therefore 27 \mathrm{Th}$ & 0.0 & $1.15 E 5$ & $6.27 \mathrm{E} 4$ & $1.89 E 5$ & $1.55 \mathrm{E5}$ & $1.31 E 5$ \\
\hline $229 \mathrm{Th}$ & 0.0 & 2.17E3 & $1.23 \mathrm{E} 3$ & $4.32 \mathrm{E} 3$ & $2.98 E 3$ & $2.95 \mathrm{E} 3$ \\
\hline $223 \mathrm{Th}$ & 0.0 & $9.46 \mathrm{E} 4$ & $5.25 \mathrm{E} 4$ & $1.93 \mathrm{E} 5$ & $1.20 \mathrm{E} 5$ & $1.17 E 5$ \\
\hline $230 \mathrm{Th}$ & C. 0 & 4. $38 \mathrm{E} 2$ & $2.70 \mathrm{E} 2$ & $9.77 \mathrm{E} 2$ & $7.69 E 2$ & $8.92 E 2$ \\
\hline $231 T h$ & 0.0 & $1.55 \mathrm{E} 4$ & $8.85 \mathrm{E} 3$ & $3.65 E 4$ & $2.37 E 4$ & $2.55 E 4$ \\
\hline $232 \mathrm{Th}$ & 0.0 & $2.09 E 2$ & $1.31 E 2$ & $5.11 E 2$ & $4.77 \mathrm{E} 2$ & $6.10 \mathrm{E} 2$ \\
\hline $23 \cdot T h$ & 0.0 & $8.57 E 3$ & $4.87 E 3$ & $1.93 E 4$ & $9.95 \mathrm{E} 3$ & $1.11 E 4$ \\
\hline $231 \mathrm{~Pa}$ & 0.0 & 3. 3IE4 & $1.70 \mathrm{E} 4$ & $5.33 E 4$ & $4.64 \mathrm{E} 4$ & $3.96 E 4$ \\
\hline $2 \div \mathrm{Pa}$ & $2.00 E 4$ & 2. U8E5 & $1.02 E 5$ & $3.31 \mathrm{E5}$ & $2.68 E 5$ & $2.34 E 5$ \\
\hline$\because \cdots \mathrm{Pa}$ & $1.17 \mathrm{E} 7$ & $1.09 E 4$ & $6.70 \mathrm{E} 3$ & $1.34 E 4$ & $1.08 E 4$ & $1.16 E 4$ \\
\hline $2: 1 \cdot p_{a}$ & $1.70 E 6$ & $1.96 \mathrm{E} 6$ & 1. $19 \mathrm{E} 6$ & $2.41 E 6$ & $2.00 E 6$ & $2.10 E 6$ \\
\hline 2300 & 0.0 & $3.40 E 2$ & $2.04 E 2$ & 8. $33 E 2$ & $8.24 \mathrm{E} 2$ & 1.0553 \\
\hline 2330 & 0.0 & $3.58 \mathrm{E} 2$ & $1.81 \mathrm{E} 2$ & $7.86 E 2$ & 6.18E? & $7.33 \mathrm{E} 2$ \\
\hline
\end{tabular}




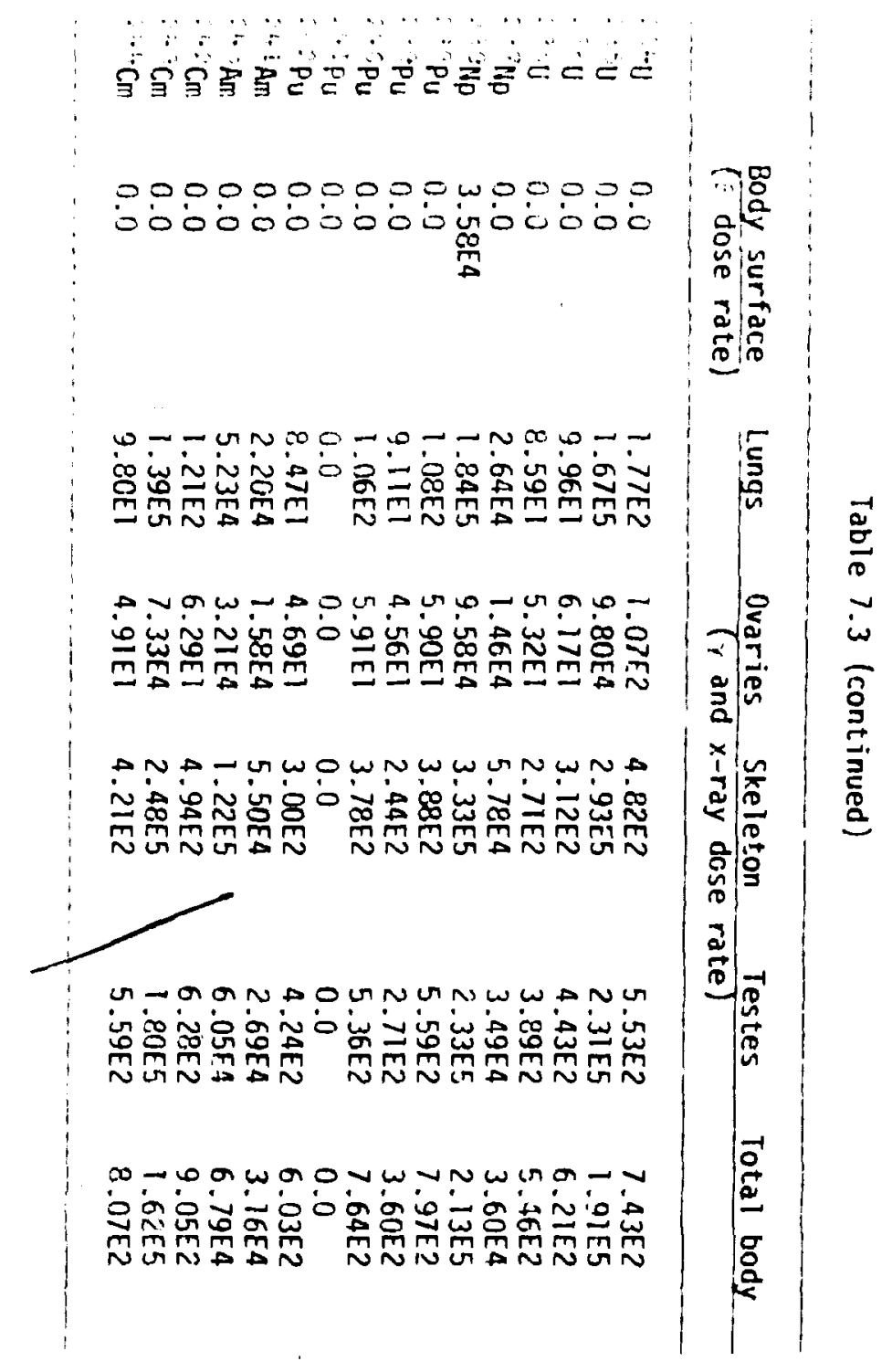


It is important to emphasize that contributions from daughter nuclides, which may be present in a given source term or which will build up due to decay of the parent radionuclide, are not included in the parent nuclide's dose conversion factor. Care must be taken, when preparing a source term to be used in the calculation of dose from a fuel cycle facility, to include such daughter nuclides as will build up during the exposure period in question, either during atmospheric transport or following deposition. External dose conversion factors for all significant daughters of breeder cycle radionuclides of interest have also been 1 sded in Tables 7.2 and 7.3 , to be used in such calculations. The reader is referred to Kocher ${ }^{6}$ for a detailed discussion of this methodology, and for diagrams of half-lives and branching fractions of radionuclides of interest. 


\section{REFERENCES}

1. Killough, G. G., D. E. Dunning, Jr., S. R. Bernard, and J. C. Pleasant. 1978. Estinates of intermai Dose Eciuijalent to 22 Trant Organs fo" Paitonuctides Oecurming in Routine Releases from Twaser. Fuel-Cycie Fasilities. ORNL/NUREG/TM-190, Vol. 1.

2. Dunning, D. E., S. R. Bernard, P. J. Halsh, G. G. Killough, and J. C. Pleasant. 1979. Estimates of Internal Dose Equivalent to

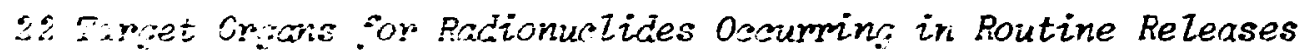

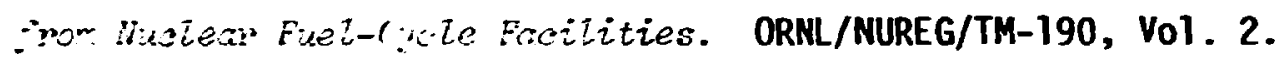

3. Morrow, P. E., D. V. Bates, B. R. Fish, T. F. Hatch, and T. T. Mercer. 1966. Deposition and retention models for internal dosimetry of the human respiratory tract. Featin Phiss. 12:173-207.

4. Eve, I. S. 1966. A review of the physiology of the gastrointestinal tract in relation to radiation doses from radioactive materials. zasition. 12:131-62.

5. International Comnission on Radiological Protection. 1977. acis:acior ac, Annals of the ICRP I, 1.

6. Kocher, D.C. 1979. Dose-Pxte Conversior. Efctors for Extemal Exycour to thoton and Eiectron Radiation from Radionuclides Occur rin: in Routine Relesses :rom Nuclear Fuel cicle Facilities. ORNL/ NUREG/TM-283. 
8. DOSES DUE TO ATMOSPHERIC RELEASES OF ${ }^{3} \mathrm{H}$ aND ${ }^{i 4} \mathrm{C}$

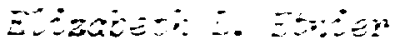

\subsection{Tritium $\left({ }^{3} \mathrm{H}\right)$}

\subsubsection{Introduction}

Various methodologies exist for the estimation of ingestion dose from continuous atmospheric releases of tritium. ${ }^{1-7}$ Most of these methodologies are based on the specific activity model (according to which the tritium content of the plant or body water, related to the content of stable hydrogen, is the same as that of the water in airl, but the resulting dose estimates may vary by up to a factor of 10 dependins on the erivilibrium assumptions employed for vegetation, beef, and milk.

Bush, Evans, ${ }^{3}$ Killough and McKay, ${ }^{3}$ and Monr $2^{4}$ base their dose calculations on the assumption that body hydroges or body water is uniformly labeled with tritium (an equilibrium rat:o of 1.0). However, their approaches are somewhat different in that Bush ${ }^{1}$ and Evans ${ }^{2}$ estimate dose based on the average energy delivered by HTO to body water that contains 1 iCi/liter. Killough and Mckay, ${ }^{3}$ and Moore, ${ }^{4}$ follow the food and water ingestion pathway.

The U.S. Nuclear Regulatory Comission, ${ }^{5}$ and $\mathrm{Ng}$ et al. ${ }^{6}$ assume various uptake fractions for tritiur, in plants, beef, and milk, resulting in doses $1 / 4-1 / 2$, respectively, those estimated by the Killough and McKay, ${ }^{3}$ and Moore ${ }^{4}$ methodologies.

Vogt ${ }^{7}$ recommends mr jifying the basic specific activity model so as to consider the wister supply of plants from the soil water and precipitation deposited or the leaves, as well as that from humidity. 
A review of the literature available for estimating dose from atmospheric reicases of tritium, as well as the range of reported values for the input parameters is being undertaken at the Oak Ridge National Laboratory (ORNL). Parameters being considered include: quality factor, half-life, air-towater dilution, and organic binding of tritium.

At present, the methodology outl ined in the AIRDOS-EPA computer code ${ }^{8}$ is being employed at ORNL for estimating tritium doses. This methodoiogy has been mudified slightly from that reported by Moore ${ }^{4}$ and may be modified furi. to reflect the changes suggested by the literature review in progress.

8.1.2 The AIRDOS-EPA methodology for ${ }^{3} \mathrm{H}$

The AIRDOS-EPA code ${ }^{8}$ treats tritium in the folluwing manner: if tritiul. (T) is released to the atmosphere as $H T$ or $T_{2}$, atoms of $T$ may exchange with hydrogen atoms in water molecules in the air, and the plume is treated as though it contained HTO initially. The tritium may then be assumed to follow water almost precisely through the environment. For this reason, doses from drinking water are included for tritium. Rather than attempting to relate the doses ti the ground deposition rate, it is assumed that doses from ingestion of food and drinking water at an environmental location are proportional to the tritium concentration in air. 3

The total ingestion dose from tritium if the source of all of an individual's food and drinking water is assumed to be at his specific environmental location is:

$$
D_{t}=C_{f^{x}}+C_{w^{x}},
$$

where

$D_{t}{ }^{\prime}=$ tritium ingestion dose from food and water (rem/year), 
$C_{f}=$ dose conversion factor for food $\left(\mathrm{rem}-\mathrm{cm}^{3} / \mathrm{pCi}\right.$-year $)$,

$C_{w}=$ dose conversion factor for drinking water (rem-cm $\left.3 / p C i-y e a r\right)$, and

$x=$ groundlevel concentration of tritium in air at the environmental location $\left(\mathrm{pCi} / \mathrm{cm}^{3}\right)$.

The total-body dose conversion factor for ingestion is $8.3 \times 10^{-5}$ rem/k $C_{i} 10$ This number is used to derive the value of $C_{f}$ and $C_{w}$, based on the specific activity of tritium in atmospheric moisture with an average specific humidity of $8 \mathrm{~g} \mathrm{H}_{2} \mathrm{O} / \mathrm{m}^{3}$ of air (ref. 3). If tritium in food is in equilibrium with atmospheric tritium and man consumes $1638 \mathrm{~g}$ of water daily in his food, $c_{f}$ is $6.18 \mathrm{rem}-\mathrm{cm}^{3} / \mathrm{pci}$-year. The $c_{w}$ value for an assumed daily drinking water intake of $1512 \mathrm{~g}$ is $5.70 \mathrm{rem}-\mathrm{cm}^{3} / \mathrm{pCi}$-year. This value is used, however, only if the source of each individual's orinking water is assumed to be at his specific environmental location. For all other cases, $C_{W}$ is reduced to account for dilution by distant sources.

The code artificially breaks down the ingestinn dose from tritium into percentage contributions of $50.5:$ from vegetables (including fruits and grains), $17.5 \%$ from meat and $31.0 \%$ from milk. The percentages are based on approximate water contents of foods: 82.4 . for vegetables, $62.3^{\circ}$ for meat, and 87.5 for milk, for daily intakes of $0.532 \mathrm{~kg}$ vegetables, $0.258 \mathrm{~kg}$ meat, and $0.307 \mathrm{~kg} \mathrm{milk} \mathrm{(Sect.} \mathrm{6).}$

Tritium doses via inhalation of air and skin absorption are estimated by the code and added to the dose estimated to be received via ingestion. The dose conversion factor for inhalation ${ }^{10}$ of air containing tritium includes a $50 \%$ contribution ror skin absorption from air. 


\subsection{Carbon-14 $\left({ }^{14} \mathrm{C}\right)$}

\subsection{1 introduction}

Methods for calculating dose to man from atmospheric releases of ${ }^{14} \mathrm{C}$ are aijo being reviewed. Basically, these methods involve a specific activity approach, although they differ in their treatment of pathways. The NRC (ref. 5) assumes that the ratio in vegetation of ${ }^{14} \mathrm{C}$ to natural carbon is the same as the ratio in the atmosphere of ${ }^{14} \mathrm{C}$ to natural carbon. The ingestion of ${ }^{14} \mathrm{C}$ in foods, including various transfer coefficients for vegetation-to-beef and vegetation-to-milk, is then used to calculate the iltimate dose to man. For intermittent releases, an account is made for achievement of a fractional equilibrium ratio by relating total anrual releases time to the total arinual time during which photosynthesis occurs.

The methodology currently in use at ORNL, and described in the AIRDOS-EPA code, ${ }^{8}$ assumes that the ${ }^{14} C$ in body tissues is in equilibrium with the ${ }^{14} \mathrm{C}$ in the atmosphere during continuous releases. Since about 99 of the dose from ${ }^{14} \mathrm{C}$ is via the ingestion pathway, ${ }^{9}$ a breakdown based on percent contribution to diet of the three major food pathways, as well as the carbon content of eacr. food, is utilized in the AIRDOSEPA code to facilitate a pathway analysis.

\subsubsection{The AIROOS-EPA methodology for ${ }^{14} \mathrm{C}$}

The description of the treatment of ${ }^{14} \mathrm{C}$ in the AIRDOS-EPA code ${ }^{8}$ is as toilows: if ${ }^{14} \mathrm{C}$ is released in the form of ${ }^{14} \mathrm{CO}_{2}$, it will mix with atmospheric $\mathrm{CO}_{2}$ and become available for plant photosynthesis'. Cattle grazing on pasture will take in ${ }^{14} \mathrm{C}$ in grass, and then man will receive 
it in milk and beef. Factors in a data statement are used in the code to multiply by the concentration of ${ }^{14} \mathrm{C}$ in air to obtain an ingestion dose for each refereice organ. These dose conversion factors, listed in Table 8.1 are based on specific activity calculations for ${ }^{14} \mathrm{C}$ in body tissues in equilibrium with ${ }^{14} \mathrm{C}$ in the atmosphere. 9

Nearly all the ${ }^{14} \mathrm{C}$ dose comes from ingestion. An artificial breakdowr: by the three food pathways is accomplished by estimating carbon inta':es for vegetables, milk, and meat, based on a carbon content of approximately 8 : for vegetables, $24 \%$ for meat, and $7_{i:}^{c}$ for mi $k$. 
Table 8.1. Dose conversion factors for ${ }^{14} \mathrm{C}$

\begin{tabular}{lc}
\hline \multicolumn{1}{c}{ Organ } & $\begin{array}{c}\text { Dose conversion factors } \\
\text { (rem-cm }\end{array}$ \\
\hline Whole body & $1.16 \times 10^{3}$ \\
Red marrow & $2.03 \times 10^{3}$ \\
Lungs & $5.07 \times 10^{2}$ \\
Endosteal cells & $1.85 \times 10^{3}$ \\
Stomach wall & $7.43 \times 10^{2}$ \\
Lower large intestine wall & $8.92 \times 10^{2}$ \\
Thyroid & $5.27 \times 10^{2}$ \\
Liver & $7.30 \times 10^{2}$ \\
Kidneys & $6.49 \times 10^{2}$ \\
Testes & $4.46 \times 10^{2}$ \\
Ovaries & $4.46 \times 10^{2}$ \\
\hline
\end{tabular}

${ }^{a}$ These factors are taken from ref. 8 and are based on the assumption that the specific activity in human tissue is equal to the average steady state value in the atmosphere (ref. 9). 


\section{REFERENCES}

1. Bush, W. R. 1972. Assessing and Controlizing the Hazard from Tritated zater. AECL-4150.

2. Evans, A. G. 1969. New dare estimates from chronic tritium exposures. Pealtir Pigs. 16:57-63

3. Killough, G. G. and L. R. McKay. 1976. \& Eetrociotogs Sor Caicuiatiry Padiation Doses from Radioactivity Released to the Envirormert. ORNL-4992.

4. Moore, R. E. 1977. The AIFDOS-II Computer OJde for Estimatire Racitation iose to :Gr from irbome Padionucitats in Areas Surroundire “uciear Faciizitiez. ORNL-5245.

5. U.S. Nuclear Regulatory Commission. 1977. Regulatory ûside i.109, Caiculation of annual doses to man from routine releases of reactor effluents for the purpose of evaluating compliance $w^{2}$ th 10 CFR Part 50 , Revision 1.

6. Ng, Y. C., W. A. Phillips, Y. E. Richer, R. K. Tandy, and S. E.

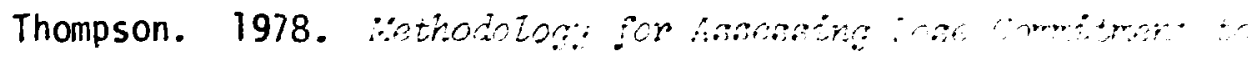

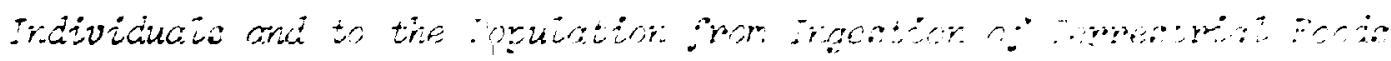

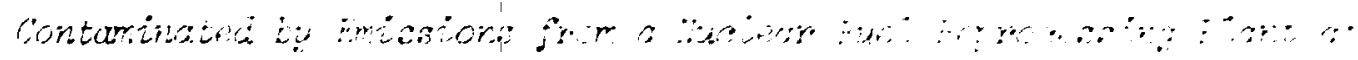
the rovannin iver lant. UCID-17743.

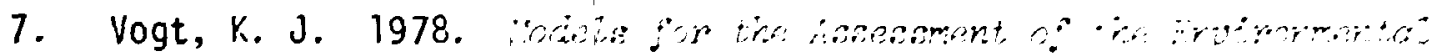

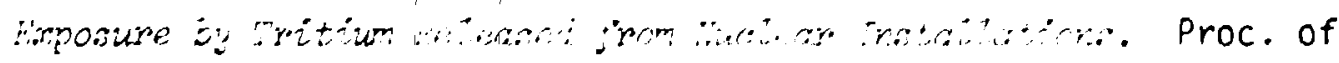
International Symposium on Behavior of Tritium in the Environment. IAEA-SM-232/15. In press.

8. Moore, R. E., C. F. Baes III, L. M. McDowell-Boyer, A. P. Watson, F. 0. Hoffman, J. C. Pleasant, and C.W. Miller. 1979. A.?

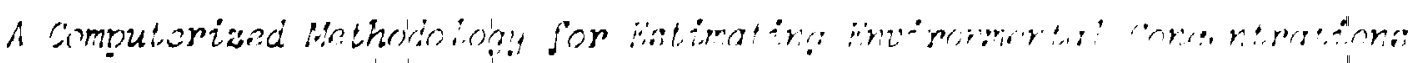

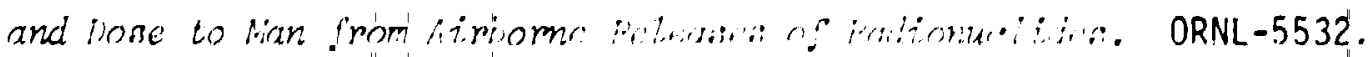


9. Killough, G. G. and P. S. Rohwer. 1978. A. new look at the dosimetry

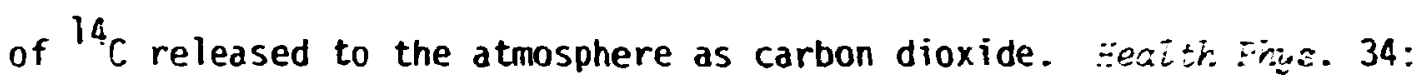
$141-59$.

1C. Killough, G. G., D. E. Dunning, Jr., S. R. Bernard, and J. C. Pleasant.

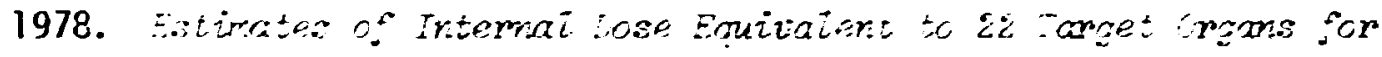

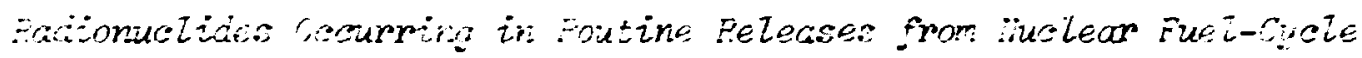
Easizities. Vol. 1, NUREG/CR-0150, ORNL/NIJREG/TM-190. 
Fppendix A

f. COMPARISOA OF EXPOSURE PETHWAS 
Releases of radionuclides to the enviroment from nuciear facilities, including breeder reactors, are generally either airborne or waterborne. In either case, there are several pathways by which humans may be exposed to radioactivity from either type of release. The main body of this report presents information on the models and parameter values which mas be used to estimate the dose to humans as a result of these exposures. The purpose of this appendix is to illustrate for both release types the relative contribution of various pathways of exposure to the total dose due to radionuclide releases from various nuclear facilities.

This comparison is accomplished through a review of pathway comparisons performed for various facilities of the light water reacior (LWR) fuel cycle.

The primary reference for the discussion of atmospheric releases was published by Hoffman and Kaye. ${ }^{1}$ Most of the data mentioned here were taken from tables published in that oaper. A primary reference for the importance of various pathways following an aquatic release is a paper by Soldat ${ }^{2}$ from the same symposium volume. While these examples do not include breeder reactor facilities, the models used in these comparisons are basically the same as those $d$ scussed in this report. As such, they should serve the illustrative purposes desirad for this appendix. Further, no single comparison oi sets of comparison can define the critical pathway or pathways to man from a given type of facility since any such comparison depends on the radionuclide make-up of the release, the rate of release, the diptary and behavioral habits 
of the human receptor, and the existence of a particular pathway at a given site.

\section{A.l Átmospheic Pelease}

Hoffman and Kaye calculated the maximum individual exposure from c)

the major terrestrial pathways for atmospheric releases from model LiR fuel cycle facilities. Each model facility resulted in a dose to the urgans of some limiting individual (adult, child or both) after aisuming a generic location and respiratory parameters desicned to maximize the exposure to humans via that iathway. These doses were then compared to applicable radiation standards to assess the significance of the particular pathway. For each facility, the principal nuclides and principal expesure pathways for organs of the limiting child or adult were listed. Rather thin reproduce those seven iables here, we have summarized the information in Table A.1. A reader desiring the detail of the original report snould see lables 8-14 of ref. 1 .

There are several observations about the pathways which may he made from the information in table A.1. One conclusion is that for the censidered ralease and human behavioral conditions milk is an extremely important pathway of exposure, especially for children. of the 31 entries in the rightmost column in lable A.I. "principal pathways for principal nuclides." 16 are milk ingestion. Milk ingestion was often the most important pathway of radiation exposure when children alone were considered.

For adults, milk ingestion was slíghtly less important, but milk, vegetable, and beef ingestion still accounted for one-half of the principal pathway entries. Immersion in contaminated air was an important 
Iable A. I Pritcipal pathays and nuclides for maximahly exposed individuals from modei tacilities in the uraniue fuel cycie:

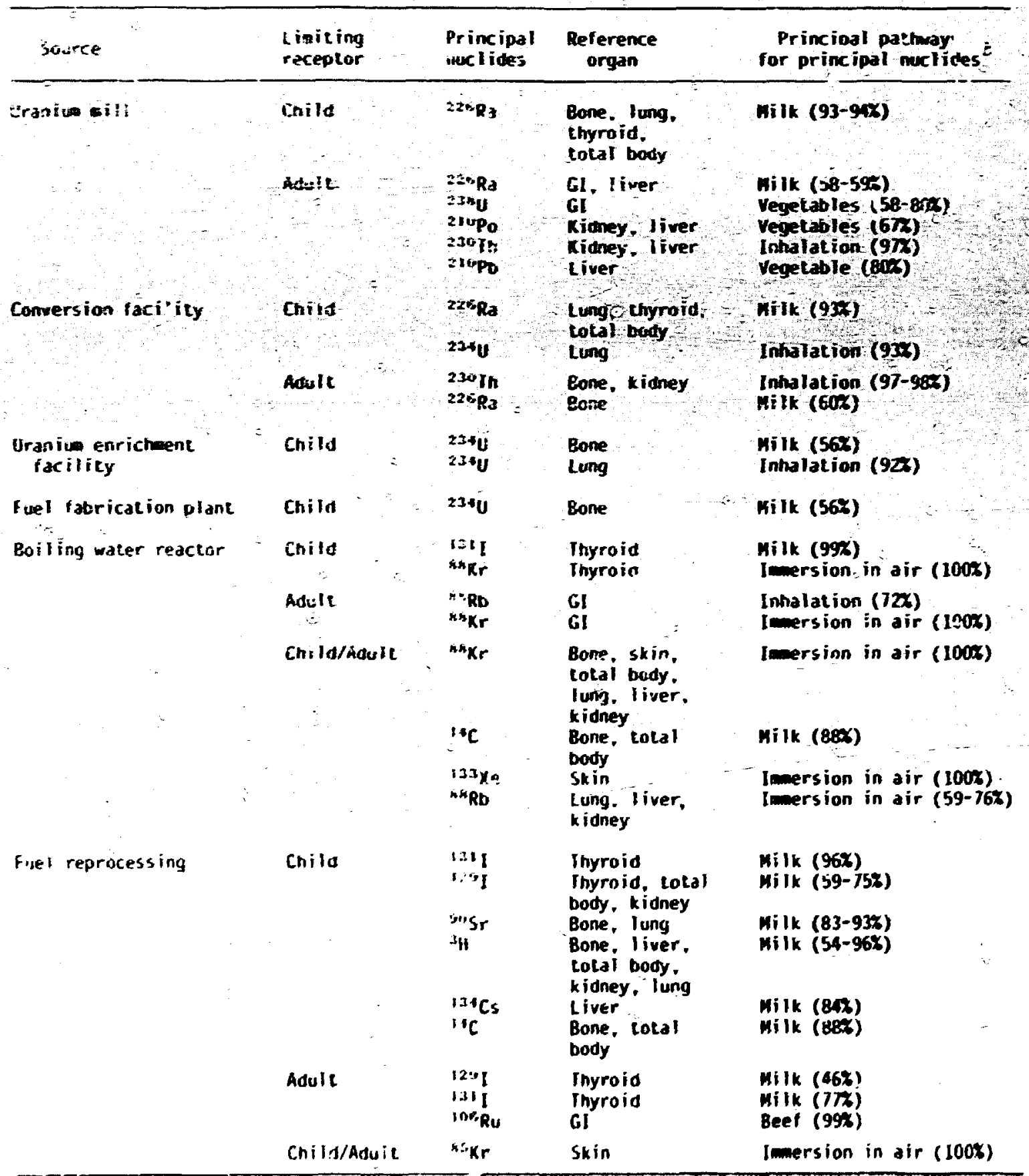

Dala Laken from Tables $8-14$ of ref. I.

Range of percentages indicates the contribution by the principal nuclide to the organs of reference o:er the listed patriwdy. 
pathway for the boiling water reactor and the fuel reprocessing plant. Inhalation was a principal pathway for adults subject to releases from uraniu mill and the uraniu conversion facilities and for children near uraniu enrichent facilities. Exposure to contaminated surfaces was found to be relatively unimportant for the releases considered in this paper.

As wight be expected, the principal tadionuclides reieased were not tfe same for each facility type. Important releases early in the fuel cycle tend to be comosed of naturally occurring radionuclides, while the principal radionuclides released by the reactor and reprocessing plant are more frequently fission products.

It is apparent from this brief discussion that the importance of the various pathways of exposure is very wuch a function of the nuclides released. Therefore, it follows that the importance of any pathway varies between types of facilities and within types of facilities, depending upon the particular radionuclides present and the emission control equipment instal led.

Studies similar to the one of Hoffman and Kaye' were performed by various authors, but for specific types of tacilities and for population do:e comitments rather than maximum individual doses (Table A.2). The data in Table A.2 from these studies are not identified by radionuclide, but the conclusions drawn from Table A.1 hold for these other studies; namely, ingestion and inhalation appear to be the most important pathways, but the relative rankings of the pathways varies between and within facility types due to differences in assumptions about radionuclide releases and environmental lransport factors. 
Table A.2 Fraction of the 50-year dose commitment to the population within 50 miles of each fuel cycle facility from gaseous relezses per year uf operation of the facilfty

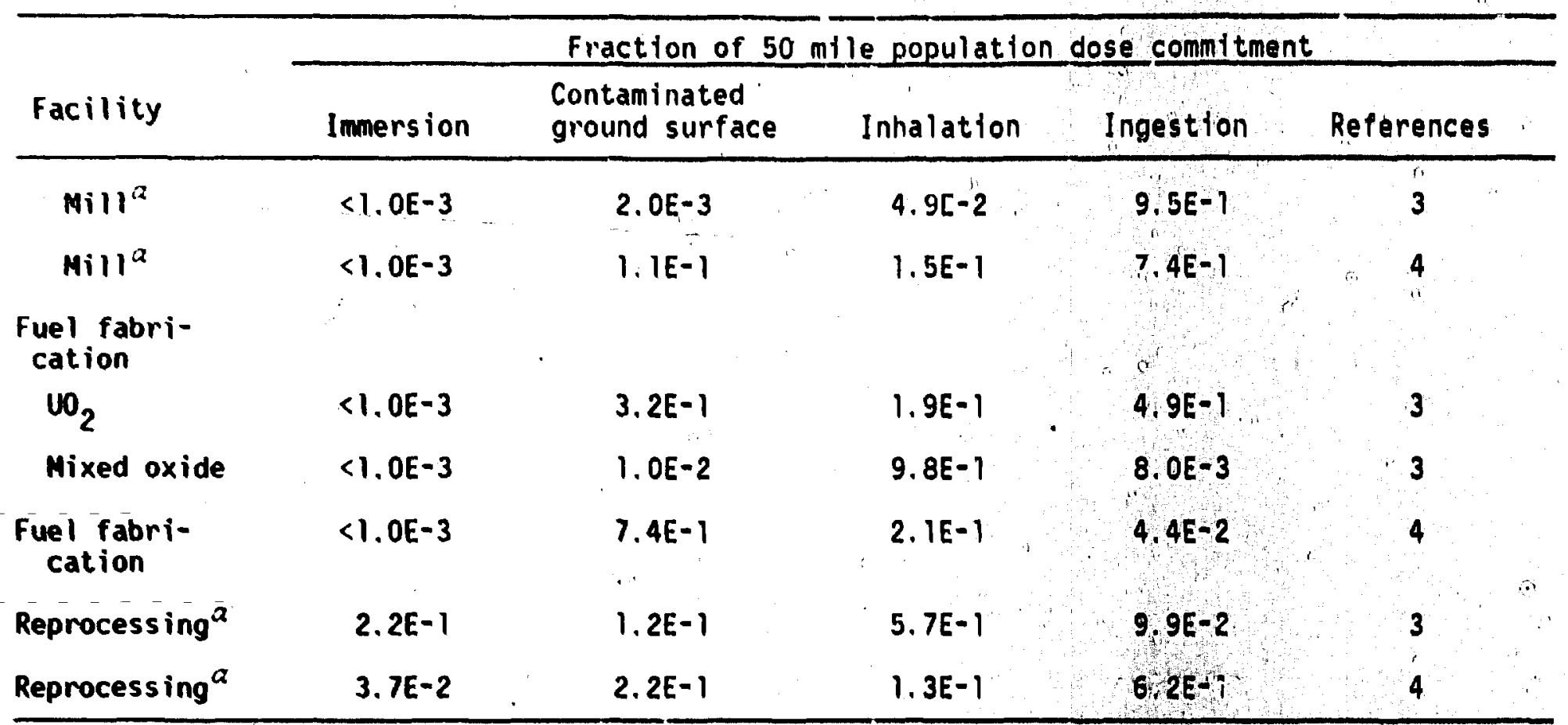

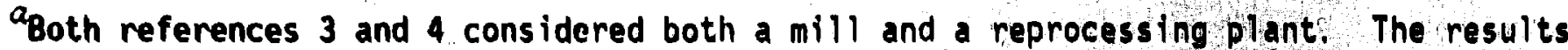
differ because of differences in source term and assumptions about the facllity. 


\section{A.2 Aquatic Releases}

We are aware of no paper examining the importance of various aquatic pathways which is directly comperable to the paper by Hoffman and Kaye - 1 An adjoining paper by Soldat ${ }^{2}$ in the same volume discusses "only the potential aquatic exposure pachways, including drinking water, aquatic foods, swimming and boating, contaminated sediments, and crops and animal products from imrigated farms." Soldat goes on to say that the importance of the various pathrays cannot be evaluated wi thout knowing the release rates and physicochemical form of the radionuclides, the type of water receiving effluent and its use by humans.

Given these precautions, Soldat ${ }^{2}$ discusses several studies of population doses from aquatic releases and attempts to compare the importance of the various pathways. Results from the studies cited by Soldat ${ }^{2}$ and two additional studies are sumarized in Table A.3. Different assumptions were used in each of these so care must be exercised when comparing them.

However, these four studies do reaffirm the point made in the atmospheric section that the importance of the fathway varies greatly depending on the organ of concern, the type of release, and the assumptions made. when calculating doses, as well as the relatinnship between the calculated dose and a dose limit. The only apparent exception to this rule is the swimming pathway which, for the studies referenced, never contributed more than $3{ }^{\prime}$ of the total calculated dose.

Aside from the constant small contribution of the swiming pathway, the relative importance of the various pathways changes frequently due to 
Toble ${ }^{2} 3$ fraction of the calculated total dose from one or more radianuclides listed by aquatic pathway in several studies.

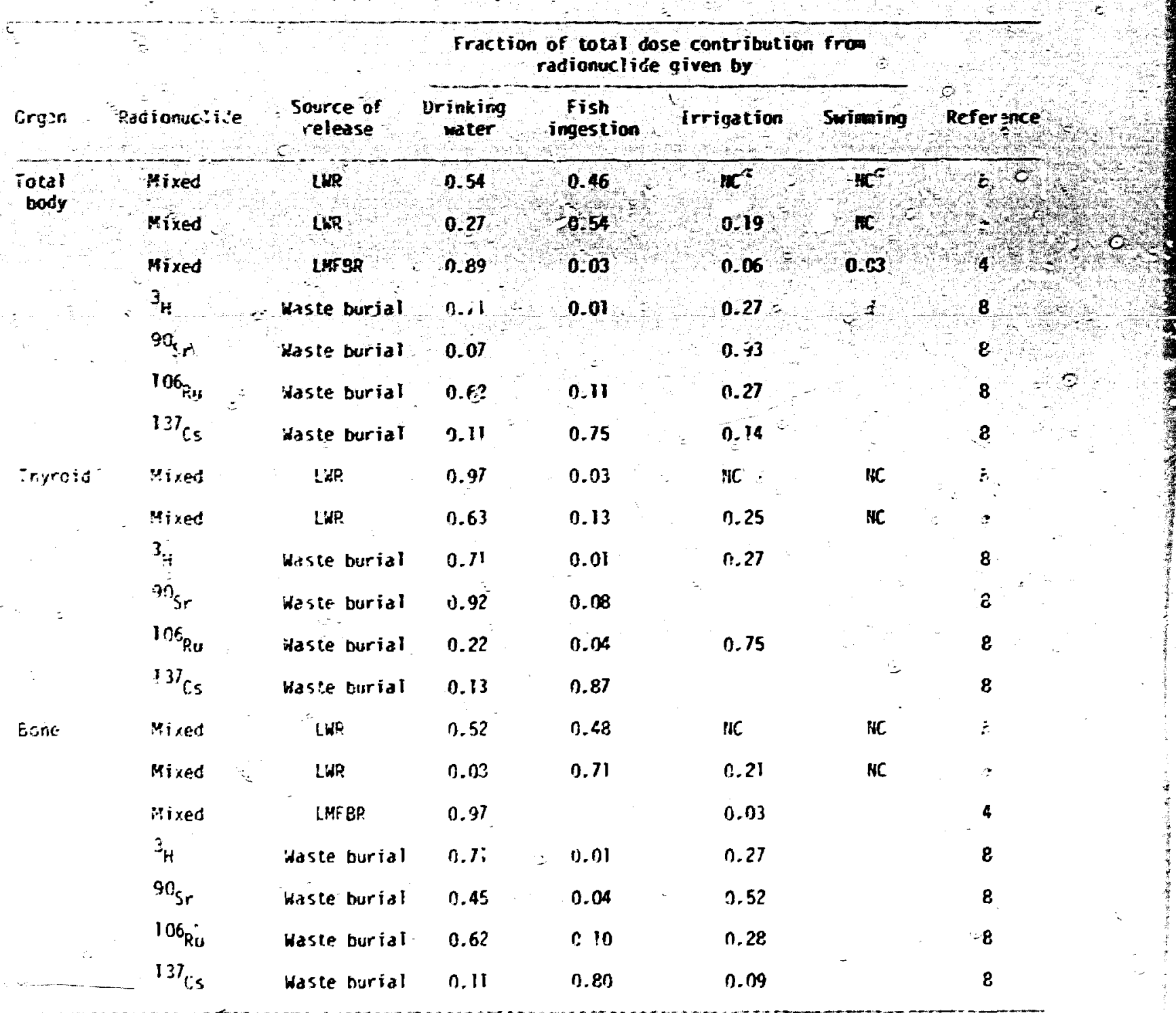

Wo calculation (NC) pati. vay not considered.

Gohbins and Martin as cited by Soldac. ${ }^{2}$

'jchuckler, Kalchbrenner, and eayer' as cited by Soldat."

contritution of this pathway is less than 1 of the total 
changes in the assumptions used in the calculations. The drinking water pathray contributes from 8 to $97 \%$ of the total dose. The fish ingestion pathay varies from negligible (less than $1 \%$ ) to as much as 87x. Finally, the irrigation pathway contributed from less than $1 \%$ to is much as 937. It is important to ramember that the range of contributions of each pathway may not be completely specified in Table A.3; itte specific considerations for almost any parameter or variable in the 10se equations may significantly alter the contribution to dose of any 9ven parameter.

Likely the most reasenable conclusion of this short review is that no single aquatic pathway to man dominates the dose calculations. Rather, the only pathway which is not very important, primarily as a result of low exposure possibility, is the swimming pathway. The only time this pathway would likely become important is if the other pathways were nonexistent at the site being considered.

\section{A.3 Relative Contribution of Atmospheric vs Aquatic Releases}

In general, an examination of the references cited in this appendix as well as other reference sources indicates that, for both individual and population doses, atmospheric releases from nuclear facilities are expected to contribute a larger fraction of the dose to humans than are aquatic releases. One reason for this expectation is that the source term for atmospheric releases is generally higher than the source term for aquatic releases. Also, humans tend to have more interaction with airborne than with waterborne radionuclides. However, variations between sites can be large enough that conditions prevailing at a specific site 
should be considered when attempting to determine the relative importance of aquatic or atmospheric exposures in the calculation of a sperific imaximally exposed individual or population dose. 


\section{REF́ERENCES}

1. Hoffman, F. O. and S. V. Kaye. 1976. Terrestrial exposure pathways: potential exposures of man from the enviromental transport of waste nuclides. pp. 524-538. IN Proceedings of the Intermational symposium on the Honagement of Wastes from the LWR Fuel rycle. Denver, Colorado, July $11-16,1976$. CONF-76-0701.

2. Soldat, J. K. 1976. Aquatic exposure pathways-potential exposure of man from environmental transport of waste radionuclides. pp. 539-553 IN Proceedings of the Internationat symposium on the Hanagement of Wastes from the LWR Fuel Cycle. Denver, Colcrado, July 11-16, 1976. CONF-76-0701:-

3. Witherspoon, J.P. 1974. Population exposure estimates as derived from an environmental assessment of LWR fuel cycle facilities.

Part 1: Population doses from operating facilities. pp. i91-198.

IN Symosiom on Population Exposures, Prosedings of the Eight rif-

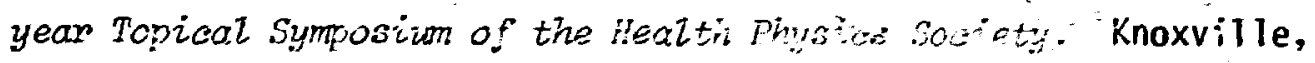
Tennessee, October $21-24,1974$. CONF-741018.

4. Rohwer, P. S., D. C. Parzyck, and S. V. Kaye. 1976. An application of the cumulative exposure index (CUEX) as an operational radiological

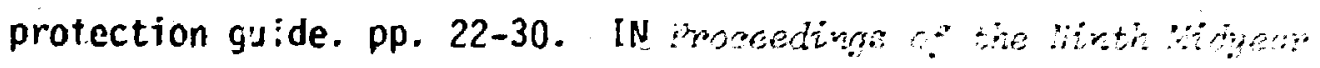

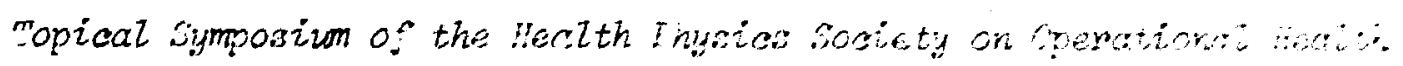
Phyzica. Denver, Colorado, February 9-12, 1976.

5. U.S. Atomic Energy Commission. 1974. Frvimomentat Reanmen, ISquid Hetal East Breeder Eeactor Progm. Vol. II. WAjH-1535. 
6. Robbins C. and J. A. Martin, Jr. 1976. Population doses from liquid effluents into the Mississippi Basin. IN Twenty-First Anmual Heeting of the Health Physics Society. San Francisco, California, June 27-July 2, 1976. (abstract).

7. Scfirckler, M., R. Kalckbrenner, and A. Bayer. 1976. Zukanftige radiologische Belastwing durch kemtechnische Anlagen im Einzugsgebiet

T. des ofernheins, Ieil II, Belastimg uber den Wasserweg. Pp. 724-726.

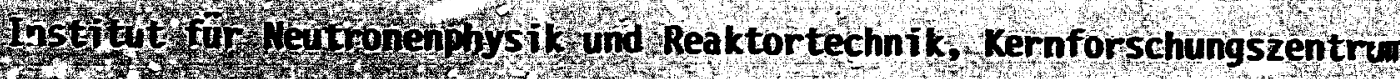
kives 5 in

8. Lit1e, C.A. and S. J. Cotter 1980. Estinated Radiotogical Doses to the Marimum Individual and Downstrean Populations from Releuses of Iritium, Strontium-90, Ruthenizon-106, and Cesium-137 from white Dak Dan. ORNL/TM-7039. 

The body of this report presents modeis and parameter values which may be used to assess the impact on man of radionuclides released to the environment by breeder reactor and other nuclear fatilities. The purpose of this appendix is to illustrate how these wodels and parameter values are used in numerical calculations. Example problens are solved for environmental concentrations and subsequent doses to huans as a result of releases to the atmosphere and surface waters for a linited nuber of nuchides. While the exaples considered are far trom exhaustive when compared to those that night be encocotered in a real assessment situation, it is hoped that these cases will be of assistance to persons attempting such calculations for the first time or to those who simply need to understand how such calculations are made. Also, these problems could be used as a partial check of computer implementations of material contained in this report.

When solving these example problems, reference is made to the location in the main body of the report whcre the equation, methodology, or parameter value being used is originally presented. The reader should consult the referenced locations for a complete definition of all of the terms used in solving the sample problem.

In tile main body of this report, information is presented on the statistical distribution associated with the parameters whenever information on the distribution could be obtained. In this appendix, mean values of these parameters are uspo in the example calculations. It must be emphasized that the selection of the mean value was an arbitrary one for illustrative purposes only, and such use here does 
not constitute a recommendation that mean values be useo for all assessment calculations. in addition, the release rates used in these example problems were also choșen arbitrarily, and no relationship beiween them and actual release rates from breecier reactors or any other nuclear facilities was intended.

\section{B. 1 Environmental Concentrations}

\section{B.1.1 Releases to the Atmosphere}

\section{B.1.1.1 Air concentration from a ground-level release. Assume} an annual release of $1 \times 10^{-2} \mathrm{Ci}$ of ${ }^{13 l_{1}} \mathrm{I}_{2}$ from a ground level $(\mathrm{H}=0 \mathrm{~m})$ source under Pesquill atmospheric stability category $D$. Because of the release height, the Pasquill-Gifford values of $\sigma_{y}$ and $\sigma_{z}$ should be used in the Gaussian plume model, Eq. (2.1). From Table 2.1, for a downwind distance of $x=2000 \mathrm{~m}$,

$$
\begin{aligned}
\sigma_{y} & =\left(a_{1} \ln x_{-}+a_{2}\right) x \\
& =(-0.0059[\ln 2000]+0.11)(2000) \\
& =130 \mathrm{~m},
\end{aligned}
$$

and

$$
\begin{aligned}
\sigma_{z} & =\frac{1}{2.15} \exp \left(b_{1}+b_{2} \ln x+b_{3} \ln ^{2} x\right) \\
& =\frac{1}{2.15} \exp \left(-1.35+0.793[\ln 2000]+0.0022[\ln 2000]^{2}\right) \\
& =57 \mathrm{~m} .
\end{aligned}
$$

Equation (2.8) for plume depletion cannot be solved analytically. However, values of the ratio $\frac{Q^{\prime}}{Q}$, the plume depletion fraction, for $v_{d}=1 \mathrm{~cm} / \mathrm{s}$ and $u=1 \mathrm{~m} / \mathrm{s}$ ran be obtained from i ig. 5.5 of Meteorology 
and Atomic Energy - 1968 (ref. 1). For a duwmind distance of $2000 \mathrm{~m}$, a release height of $0 \mathrm{~m}$, and Pasquill 0 stability, Fig. 5.5 gives $\frac{Q^{\prime}}{Q}=0.35$. Assume that the actual wind speed for the $131 I_{2}$ release being considered here is $3 \mathrm{~m} / \mathrm{s}$. Further assime that $v_{d}(t o t a l)=$ $3.5 \mathrm{~cm} / \mathrm{s}$ (Sect. 2.2 .1 ) and $v_{w}=1.3 \mathrm{~cm} / \mathrm{s}$ (ret. 2). This results in a total deposition velocity of $4.8 \mathrm{~cm} / \mathrm{s}$. The value of $\frac{Q^{\prime}}{Q}$ noted ahove can now be changed to reflect the assuned release conditions by

$$
\begin{aligned}
\left(\frac{Q^{\prime}}{Q}\right)_{2} & =\left(\frac{Q^{\prime}}{Q}\right)_{1}^{\frac{u_{1} v_{2}}{u_{2} v_{1}}} \\
& =(0.35)^{\frac{(1 \mathrm{~m} / \mathrm{s})(4.8 \mathrm{~cm} / \mathrm{s})}{(3 \mathrm{~m} / \mathrm{s})(1 \mathrm{~cm} / \mathrm{s})}} \\
& =0.19
\end{aligned}
$$

This indicates that the deposition processes considered here result in an air concentration at $2000 \mathrm{~m}$ that is $19 \%$ of the air concentration that would be expected if these deposition processes were not considered.

The half-life, $t_{1 / 2}$, of ${ }^{131} I$ is 8.05 days (ref: 3 ). Threfore, the radiological decay constant, $\lambda$, is $9.96 \times 10^{-7} \mathrm{~s}^{-1}$.

Equation (2.1) may be used to calculate the ground-level, centerline air concertration. Accounting for decay and plume depletion, Eq. (2.1) becomes

$$
x=\left[\frac{Q}{\pi \omega \sigma_{y} \sigma_{z}} \exp \left(-\lambda \frac{x}{u}\right)\right]\left(\frac{Q^{\prime}}{Q}\right)_{2}
$$




$$
\begin{aligned}
Q & =1 \times 10^{-2} \mathrm{Ci} / \text { year }=3.2 \times 10^{-10} \mathrm{Ci} / \mathrm{s} \\
X & =\left[\frac{\left(3.2 \times 10^{-10} \frac{\mathrm{Ci}}{\mathrm{s}}\right)}{\pi(3 \mathrm{~m} / \mathrm{s})(130 \mathrm{~m})(57 \mathrm{~m})} \exp (-[9.96 \mathrm{E}-7][2000 / 3])\right]( \\
& =8.7 \times 10^{-16} \mathrm{ci} / \mathrm{m}^{3}
\end{aligned}
$$

The $22.5^{\circ}$ sector average air concentration, based on Eq. (2.2), is given by

$$
\begin{aligned}
x & =\left[\frac{2.032 g}{x \cup 0} \exp \left(-\lambda \frac{x}{u}\right)\right]\left(\frac{Q^{\prime}}{Q}\right)_{2} \\
& =\left[\frac{(2.032)\left(3.2 \times 10^{-10} \frac{\mathrm{Ci}}{\mathrm{s}}\right)}{(2000 \mathrm{~m})(3 \mathrm{~m} / \mathrm{s})(57 \mathrm{~m})} \exp (-[9.96=-7][2000 / 3])\right] \\
& =3.6 \times 10^{-16 \frac{\mathrm{ci}}{3}}
\end{aligned}
$$

B. 1.1.: Air concentration from an elevated release. Assume an annual rele.1se of $100 \mathrm{Ci}$ of ${ }^{85} \mathrm{Kr}$ from a $100-\mathrm{m}$ tall stack. Since $\mathrm{Kr}$ is a nonreactive gas and it has a half-life of 10.76 years (ref. 3 ), radiological decay and plume depletion need not be considered in this calculation. Ising the Brookhaven dispersion parameters for this elevated release ana assuming class $\mathcal{B}_{1}$ stability and a downwind distance of $2 \mathrm{~km}$, Table 2.2 gives

$$
\begin{aligned}
\sigma_{z} & =p_{z} x^{q_{z}} \\
& =(0.33)\left[(2000 \mathrm{~m})^{0.86}\right] \\
& =230 \mathrm{~m}
\end{aligned}
$$


If $u=4 \mathrm{~m} / \mathrm{s}$, the $22.5^{\circ}$ sector-average air concentration for this reîlease is, from Eq. (2.2),

$$
\begin{aligned}
& x=\frac{2.0320}{x \omega 0 \sigma_{z}} \exp \left\{-1 / 2\left(\frac{H}{\sigma_{z}}\right)^{2}\right\} \\
& =\frac{(2.032)\left(3.2 \times 10^{\left.-6 \frac{\mathrm{Ci}}{\mathrm{s}}\right)}\right.}{(2000 \mathrm{~m})(4 \mathrm{~m})(230 \mathrm{~m})} \exp \left\{-1 / 2\left(\frac{100 \mathrm{~m}}{230 \mathrm{~m}}\right)^{2}\right\} \\
& =3.2 \times 10^{-12} \mathrm{ci/ \textrm {m } ^ { 3 }}
\end{aligned}
$$

B.1.1.3 Ground deposition. The rate of dry deposition onto the earth's surface is given by Eq $(2.4)$ as

$$
\mathbf{d}=\mathbf{x} \mathbf{v}_{\mathbf{d}}
$$

Using the information contained in Sect. B.1.1.1 for a ground-level atmospheric release of $13 I_{I_{2}}$,

$$
\begin{aligned}
& v_{d}=3.5 \mathrm{~cm} / \mathrm{s} \\
& x=3.6 \times 10^{-16}{\mathrm{ci} / \mathrm{m}^{3}}^{3}
\end{aligned}
$$

and

$$
\begin{aligned}
d & =x v_{d} \\
& =\left(3.6 \times 10^{-16} \mathrm{ci} / \mathrm{m}^{3}\right)\left(3.5 \times 10^{-2} \mathrm{~m} / \mathrm{s}\right) \\
& =1.3 \times 10^{-17} \mathrm{ci} / \mathrm{m}^{2}-\mathrm{s} \\
& =4.7 \times 10^{-2} \mathrm{DCi} / \mathrm{m}^{2}-\mathrm{h}
\end{aligned}
$$

B.1.1.3.1 Concentration on grass. The concentration in and on grass as a result of the deposition rate calculated above is given by Eq. (3.1) as 


$$
c_{i}^{v}=d_{i}\left\{\frac{R\left[1-\exp \left(-\lambda_{E i} t_{e}\right)\right]}{V_{v}{ }^{\lambda} E i}+\frac{B_{i v}\left[1-\exp \left(-\lambda_{i} t_{b}\right)\right]}{P \lambda_{i}} \mid \operatorname{expi-\lambda _{i}t_{h})}\right.
$$

The input parameter values for this case are

$$
\begin{aligned}
& d_{j}=4.7 \times 10^{-2} \mathrm{pCi} / \mathrm{m}^{2}-\mathrm{h} \text { (1 rom above). } \\
& \frac{R}{Y_{v}}=2 \Omega^{2} / \mathrm{kg} \text { (Table 3.1). } \\
& \lambda_{E j}=6.4 \times 10^{-3} h^{-1}(\text { ref } 4) \text {. } \\
& \left.t_{\mathrm{e}}=720 \mathrm{~h} \text { (Table } 3.7\right) \text { ? } \\
& B_{i v}=2.0 \times 10^{-1} \text { (Table 3.2), } \\
& \lambda_{i}=3.6 \times 10^{-3} h^{-1} \text { (ref. 3), } \\
& P=215 \mathrm{~kg} / \mathrm{m}^{2} \text { (Table 3.6), } \\
& t_{b}=8.76 \times 10^{3} \mathrm{~h} \text { (assuned), } \\
& \left.t_{h}=0 \text { (Table } 3.7\right) \text {. }
\end{aligned}
$$

The resulting concentration of ${ }^{13 I} l$ in or on the grass is

$$
c_{i}^{v}=15 \mathrm{pCi} / \mathrm{kg} \text {. }
$$

\section{B.1.1.3.2 Concentration on fresh produce. Equation (B.9) can} also be used to estimate the concentrations in and on fresh produce as a result of the deposition of ${ }^{131}$ I considered above. Assuming this fresh produce is leafy vegetables, the input parameter values for this case are

$$
\begin{aligned}
d_{i} & =4.7 \times 10^{-2} \mathrm{pCi} / \mathrm{m}^{2}-\mathrm{h} \text { (from above), } \\
R & =0.2(\text { Table } 3.1), \\
Y_{v} & =1.9 \mathrm{~kg} / \mathrm{m}^{2}(\text { Table } 3.1), \\
\Lambda_{E i} & =6.4 \times 10^{-3} \mathrm{~h}^{-1} \text { (ref. 4), }
\end{aligned}
$$




$$
\begin{aligned}
& t_{e}=1440 \text { h (Table 3.7), } \\
& B_{\text {iv }}=5.5 \times 10^{-2} \text { (Table 3.3). } \\
& \lambda_{i}=3.6 \times 10^{-3} \mathrm{~h}^{-1} \text { (ref. 3), } \\
& \left.P=215 \mathrm{~kg} / \mathrm{m}^{2} \text { (Table } 3.6\right) \text {. } \\
& t_{\mathrm{t}}=8.76 \times 10^{3} \mathrm{~h} \text { (assuned), } \\
& t_{h}=336 \mathrm{~h} \text { (Table 3.7). }
\end{aligned}
$$

Entering these vaises into Eq- (B.9) results in a concentration of ${ }^{131} \mathrm{I}$ in or on leafy vegetables of

$$
c_{i}^{v}=2.3 \times 10^{-1} \mathrm{pCi} i \mathrm{~kg}
$$

B.1.1.3.3 Concentration in milk. Assume tliat both beef and dairy cattle are getting $100 \%$ of their food from the grass considered in Sect. B.1.1.3.1. The resulting concentration of ${ }^{131} 1_{1}$ in milk produced by these dairy cattle is, from Eq. (3.2),

$$
c_{i}^{H}=F_{m} c_{i}^{v} Q_{F} \exp \left(-\lambda_{i} t_{f}\right)
$$

The input parameter values are

$$
\begin{aligned}
& \left.F_{\text {m }}=1.0 \times 10^{-2} \text { day/liter (Table } 3.4\right), \\
& C_{i}^{v}=15 \mathrm{pCi} / \mathrm{kg} \text { (see above), } \\
& \left.Q_{F}=15.6 \mathrm{~kg} / \text { day (Table } 3.6\right), \\
& t_{f}=4 \text { days }(\text { Table } 3.7), \\
& \left.\lambda_{i}=8.6 \times 10^{-2} \text { day }^{-1} \text { (ref. } 3\right),
\end{aligned}
$$

resulting in

$$
C_{i}^{M}=1.6 \mathrm{pCi} / 1 \text { iter. }
$$


B.1.1.3.4 Concentration in beef. Similarly, the concentration of ${ }^{131} I$ in beef way be found using Eq. (3.4),

$$
c_{i}^{F}=F_{f} C_{i}^{v} Q_{F} \exp \left(-\lambda_{i} t_{s}\right)
$$

and the new input values of

$$
\begin{aligned}
& F_{f}=7 \times 10^{-3} \text { day/kg (Table } 3.5 \%, \\
& \left.t_{s}=20 \text { days (Table } 3.7\right) .
\end{aligned}
$$

and

This calculation results in

$$
c_{i}^{F}=2.9 \times 10^{-1} \mathrm{pCi} / \mathrm{kg} \text {. }
$$

\section{B. 1.2 Release to Surface Water}

B.1.2.1 Surface water concentrations. The fundamental form of the model for surface water concentration without sorption is given by Eq. (4.1). This model cannot be solved in general, however, without resorting to computerized numerical techniques. If, however, we assume c vertical line source emitting a constant $\mathrm{W} \mathrm{Ci/s,} \mathrm{a} \mathrm{closed} \mathrm{form} \mathrm{solu-}$ tion of Eq. (4.î) can be obtained (ref. 5). If we further assume a uniform, straight, rectangular channel in which the water flows, the solution to Eq. (4.2) is given by (ref. 5)

$$
c_{i}=\frac{W}{Q}\left[1+2 \sum_{n=1}^{\infty} \exp \left(-\frac{n^{2} \pi^{2} x k y}{u y^{2}}\right)\left\{\cos ^{2}\left(\frac{n \pi b}{y}\right)\right\}\right]
$$


where

$$
\begin{aligned}
& Q=\text { total river flow }\left(\mathrm{m}^{3} / \mathrm{s}\right), \\
& b=\text { cross-stream location of sampling point }(m) \text {, and }
\end{aligned}
$$

she other parameters are as deiined for Eq. (4.2). Using flow parameters based on Hudson River data (ref. 6) and a discharge rate of 1 $C: / s$ of ${ }^{137} \mathrm{Cs}$, the input paraneter values are

$$
\begin{aligned}
& W=1 \times 10^{-6} \mathrm{ci} / \mathrm{s}, \\
& Q=1600 \mathrm{~m}^{3} / \mathrm{s}, \\
& K_{y}=5 \mathrm{~m}^{2} / \mathrm{s}, \\
& u=0.6 \mathrm{~m} / \mathrm{s}, \\
& y=600 \mathrm{~m}, \\
& x=2000 \mathrm{~m}, \\
& b=200 \mathrm{~m} .
\end{aligned}
$$

Considering only the first three terms of the series expansion,

$$
\begin{aligned}
& c_{i}=\frac{\left(1 \times 10^{-6} \mathrm{ci} / \mathrm{s}\right)}{\left(1600 \mathrm{~m}^{3} / \mathrm{s}\right)}\left[1+2 \sum_{n=1}^{3} \exp \left(-\frac{n^{2} \pi^{2}[2000 \mathrm{~m}]\left[5 \frac{\mathrm{m}}{\mathrm{s}}\right]^{2}}{[0.6 \mathrm{~m} / \mathrm{s}][600 \mathrm{~m}]^{2}}\right)\right. \\
& \left.\quad \cdot\left\{\cos ^{2}\left(\frac{\mathrm{nn}[200 \mathrm{~m}]}{[600 \mathrm{~m}]}\right)\right\}\right] \\
& =\left(6.2 \times 10^{-10}\right)[1+2(0.16+0.04+0.02)] \\
& =9 \times 10^{-10} \mathrm{Ci} / \mathrm{m}^{3} \\
& =9 \times 10^{-13} \mathrm{ci} / 1 \mathrm{iter}
\end{aligned}
$$


B. 1.2.2 Concentration in fish. Assume that freshwater finfish inhabit the stream considered above. The concentration $\mathrm{CF}_{i}(\mathrm{Ci} / \mathrm{kg})$ of ${ }^{137} \mathrm{Cs}$ in these fish is given by

$$
C F_{i}=B_{i p} C_{i}
$$

If we further assume that no site-specific information is available on the concentration of $K$ in this stream, a mean value of $B_{i p}$ can be obtained from Table 5.1. This results in

$$
\begin{aligned}
\text { CF }_{\mathbf{i}} & =(1900 \text { liter } / \mathrm{kg})\left(9.1 \times 10^{-13} \text { (i/liter }\right) \\
& =1.7 \times 10^{-9} \mathrm{Ci} / \mathrm{kg}
\end{aligned}
$$

\section{B.2 Dose Calculations}

\section{B.2.1 External Doses}

B.2.1.1 Immersion ir. contaminated air. The external dose rate to an individual immersed in contaminated air is given by (ref. 7)

$$
R_{i j}^{e a}=D_{i j} x_{i}
$$

where

$$
\begin{aligned}
R_{i j}^{e a}= & \text { dose rate to organ } j \text { due to immersion in air contaminated } \\
& \text { with radionuclide } i \text { (millirem/year), } \\
0_{i j}^{e a}= & \text { dose conversion factor due to immersion in air for radio- } \\
& \text { nuclide } \left.i \text { and organ } j \text { (millirem/year per } \mu \mathrm{Ci} / \mathrm{cm}^{3}\right), \\
x_{j}^{a}= & \text { concentration uf radionuclide } i \text { in air }\left(\mu \mathrm{Ci} / \mathrm{cm}^{3}\right) .
\end{aligned}
$$


From Sect. R.1.1.1 above, a $22.5^{\circ}$ sector-averaged air concentration for a ground-level release of ${ }^{131_{1}}{ }_{2}$ was found to be

$$
\begin{aligned}
x_{i}^{a} & =3.6 \times 10^{-16} \mathrm{Ci}^{3} \mathrm{~m}^{3} \\
& =3.6 \times 10^{-16} \mu \mathrm{Ci} / \mathrm{cm}^{3}
\end{aligned}
$$

From Table 7.2 the dose conversion factor for the $\beta$ dose rate to the body surface from ${ }^{13 I_{1}} I_{2}$ is found to be

$$
D_{i j}^{e a}=1.71 \times 10^{9} \text { milliren/year per } \mu \mathrm{Ci} / \mathrm{cm}^{3}
$$

Therefore, for this release the annual $\beta$ dose rate to the body surface is

$$
\begin{aligned}
R_{i j}^{e d} & =\left(1.71 \times 10^{9} \frac{\text { millirem }}{\text { year }} \frac{\mathrm{cm}^{3}}{\mu \mathrm{Ci}}\right)\left(3.6 \times 10^{-16} \frac{\mathrm{\mu Ci}}{\mathrm{cm}^{3}}\right) \\
& =6.2 \times 10^{-7} \mathrm{millirem} / \text { year } .
\end{aligned}
$$

Similar calculations can be performed for other organs listed in Table 7.2. The resulting $Y$ and $X$-ray dose rates for all organs considered are as follows:

Organ

Bociy surface

Lungs

Ovaries

Skelezon

Testes

Total body
Dose rate, millirem/year

$6.2 \times 10^{-7}$

$7 \times 10^{-7}$

$3.3 \times 10^{-7}$

$9.8 \times 10^{-7}$

$8.9 \times 10^{-7}$

$7.6 \times 10^{-7}$

Section B.1.1.2 gives an air concentration for an elevated release of ${ }^{85} \mathrm{Kr}$, 


$$
\begin{aligned}
x_{i}^{a} & =3.2 \times 10^{-12} \mathrm{ci} / \mathrm{m}^{3} \\
& =3.2 \times 10^{-12} \mathrm{k} \mathrm{Ci} / \mathrm{cm}^{3}
\end{aligned}
$$

Using Eq. (B. 14) and Table 7.2, the annual $\beta$ and photon cose rates for this release condition are found to be the following:

\begin{tabular}{lc} 
Organ & Dose rate, millirem/year \\
\hline Body surface & $7.2 \times 10^{-3}$ \\
Lungs & $3.7 \times 10^{-5}$ \\
Ovaries & $1.5 \times 10^{-5}$ \\
Skeleton & $4.8 .10^{-5}$ \\
Testes & $.4 \times 10^{-5}$ \\
Total body & $3.9 \times 10^{-5}$
\end{tabular}

B.2.1.2 Exposure to contaminated ground. The external dose rate to an individual as a result of exposure to a radionuclide depnsited on the ground is found from (ref. 7)

$$
R_{i j}^{c g}=d_{i} \frac{1-\exp \left(-\lambda_{T} t\right)}{\lambda_{T}} D_{i j}^{c g}\left(8.64 \times 10^{4}\right) \text {, }
$$

where

$$
\begin{aligned}
P_{i j}^{C g}= & \text { dose rate to organ } j \text { due to exposure to ground contaminated } \\
& \text { with radionuclide } i \text { (millirem/year), } \\
d_{i}= & \text { rate of deposition onto ground of radionuclide } i\left(\mu \mathrm{C} / \mathrm{cm}^{2} \cdot 5\right), \\
\lambda_{T}= & \text { radioactive decay constant } \lambda_{r}+\text { environmental decay constant } \\
& \lambda_{w}\left(\text { day }^{-1}\right), \\
t= & \text { time allotted for surface buildup (days), }
\end{aligned}
$$


$0_{i j}^{C g}=$ dose conversion factor for radionuclide $i$ and organ $j$ due to surface exposure to an infinite plane at a point $1 \mathrm{~m}$ above ground ( $m$ illirem/year per $\mu \mathrm{Ci} / \mathrm{cm}^{2}$ ),

$8.64=10^{4}=$ s/day.

Section B. 1.1.3 gives a dry deposition rate onto the earth's surface resulting from a grouna-level release of ${ }^{131_{1}}{ }_{2}$,

$$
\begin{aligned}
d_{j} & =1.3 \times 10^{-17} \mathrm{ci} / \mathrm{m}^{2} \mathrm{~s} \\
& =1.3 \times 10^{-15} \mathrm{\mu Ci} / \mathrm{cm}^{2}-\mathrm{s}
\end{aligned}
$$

If a one year surface buildup time and no losses from the surface due to weathering effects are assumed, then -

$$
\begin{aligned}
\lambda_{T} & =\lambda_{r}=3.61 \times 10^{-2} d^{-1} \\
t & =365 d
\end{aligned}
$$

and

$$
\begin{aligned}
& R_{i j}^{c g}=\left(1.3 \times 10^{-15 \mu c i}\right) \frac{\left(1-\exp \left[-\left\{8.61 \times 10^{-2} d^{-1}\right\}\{365 d\}\right]\right)}{\left(8.61 \times 10^{-2} d^{-1}\right)} \\
& \text { - }\left(8.64 \times 10^{4} \frac{\overline{\dot{j}}}{\mathrm{~d}}\right) 0_{\mathrm{ij}}^{\mathrm{cg}} \\
& =\left(1.3 \times 10^{-9} \frac{\mu C i}{\mathrm{~cm}^{2}}\right) 0_{i j}^{c g}
\end{aligned}
$$

Values of $D_{i j}^{c g}$ for various organs may be found in Table 7.3 For the $\beta$ dose rate to the body surface from ${ }^{131} 1$,

$$
D_{i j}^{c g}=3.25 \times 10^{5} \frac{\text { millirem }}{\text { year }} \cdot \frac{\mathrm{cm}^{2}}{\mu \mathrm{ci}} .
$$


Therefore, for this tissue,

$$
\begin{aligned}
R_{i j}^{c g} & =\left(1.3 \times 10^{-9} \frac{\mu C i}{\mathrm{~cm}^{2}}\right)\left(3.25 \times 10^{5} \frac{\text { millirem }}{\text { year }} \cdot \frac{\mathrm{cm}^{2}}{\mu C i}\right) \\
& =4.2 \times 10^{-4} \mathrm{mill} \text { irem/year. }
\end{aligned}
$$

Similar calculations for the remaining organs 1 isted in Table 7.3 compiete the following table of dose rates:

\begin{tabular}{ll} 
Organ & Dose rate, millirem/year \\
\hline Body surface & $4.2 \times 10^{-4}$ \\
Lungs & $5.4 \times 10^{-4}$ \\
Ovaries & $2.5 \times 10^{-4}$ \\
Skeleton & $7.5 \times 10^{-4}$ \\
Testes & $6.8 \times 10^{-4}$ \\
Total body & $-5.8 \times 10^{-4}$
\end{tabular}

\section{B.2.2 Internal Doses}

B.2.2.I Inhalation dose. The dose rate to various organs of the body as a result of inhaling contaminated air is given by (ref. 7 )

$$
R_{i j}^{b r}=x_{i}^{a} B_{r} D_{i j}^{b r}
$$

where

$$
\begin{aligned}
R_{i j}^{b r}= & \text { dose rate to organ } j \text { due to breathing air contaminated } \\
& \text { with radionuclide } i \text { (rem/year), } \\
x_{i}^{a}= & \text { concentration of radionuclide } i \text { in air }\left(\frac{\mu C i}{m^{3}}\right), \\
B_{r}= & \text { breathing rate }\left(\frac{m^{3}}{y \in a r}\right), \\
D_{i j}^{b r}= & \text { dose conversion factor for radionuclide } i \text { and organ } j \text { due } \\
& \text { to breathing of contaminated air }(r e m / \mu C i \text { intare). }
\end{aligned}
$$


From Table 6.1,

$$
B_{r}=8.03 \times 10^{3} \mathrm{a}^{3} / \text { year. }
$$

Frow Sect. B. 1.1.1 for ${ }^{131} I_{2}$,

$$
\begin{aligned}
x_{i}^{a} & =3.6 \times 10^{-16} \mathrm{Ci} / \mathrm{m}^{3} \\
& =3.6 \times 10^{-10} \mu \mathrm{Ci} / \mathrm{m}^{3}
\end{aligned}
$$

From Table 7.1 for the thyroid,

$$
D_{i j}^{b r}=1.13 \frac{\mathrm{rea}}{\mu \mathrm{Ci}}
$$

The resulting annual dose rate to the thyroid for this release of ${ }^{131_{I_{2}}}$ is then

$$
\begin{aligned}
R_{i j}^{b r} & =\left(3.6 \times 10^{-10} \frac{\mu C(i}{\mathrm{m}^{3}}\right)\left(8.03 \times 10^{3} \frac{\mathrm{m}^{3}}{\text { year }}\right)\left(1.13 \frac{\mathrm{rem}}{\mu C \mathrm{i}}\right) \\
& =3.3 \times 10^{-6} \mathrm{rem} / \text { year } \\
& =3.3 \times 10^{-3} \mathrm{mill} \mathrm{irem} / \text { year. }
\end{aligned}
$$

The doses to the remaining organs listed in Table 7.1 are also esimated from the application of Eq. (B. 16) and included in the following:

\begin{tabular}{lr} 
Organ & Dose rate, milliren \\
\cline { 2 - 2 } Thyroid & $3.3 \times 10^{-3}$ \\
Lungs & $6.9 \times 10^{-6}$ \\
Total body & $1.8 \times 10^{-6}$ \\
Ovaries & $1.2 \times 10^{-7}$ \\
Total encosteal cells & $6.4 \times 10^{-7}$ \\
Testes & $6.4 \times 10^{-8}$
\end{tabular}

Note that inhalation calculations are not made for ${ }^{85} \mathrm{Kr}$ since it is assumed that the inhalation doses from noble gases are insignificant when compared to air inmersion doses. 
B.2.2.2 Ingestion doses." The calculation of dose to humans as a result of ingestion of contaminated food is analagous to the calculation of irhalation doses as expressed by Eq. (B. 16) (ref. 7),

$$
\mathbf{R}_{\mathbf{i} \mathbf{j}}^{\mathbf{f}}=\mathbf{C}_{\mathbf{i}} \mathbf{U}_{\mathbf{i}}^{\mathbf{f}} \mathbf{D}_{\mathbf{i} \mathbf{j}}^{\mathbf{f}}
$$

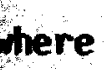

B.2.2.2.1 Ingestion of fresh produce. The concentration of ${ }^{131}$ in leafy vegetables from the ground-level reiease of ${ }^{13 I_{1}}$ being considered in this appendix was found in Sect. B.1.1.3.2 to be

$$
\begin{aligned}
c_{i}=c_{i}^{v} & =2.3 \times 10^{-1} \mathrm{pCi} / \mathrm{kg} \\
& =2.3 \times 10^{-7} \mu \mathrm{Ci} / \mathrm{kg} .
\end{aligned}
$$

Table 6.1 gives an annual average adult intake rate for leafy vegetables of

$$
u_{i}^{f}=18 \mathrm{~kg} / \text { year }
$$


assuming all of the leafy vegetables a person consumes are grown in the area effected by the release being. considered. From Table 7.1 the ingestion dose conversion for $i=|3|_{I}$ and $j=$ thyroid is found to be

$$
D_{i j}^{f}=1.81 \mathrm{rem} / \mu \mathrm{Ci}
$$

It follows from Eq- (B. I7) that the dose rate to the thyroid in this example is

$$
\begin{aligned}
\mathbf{R}_{i j}^{f} & =\left(2.3 \times 10^{-7} \mu C i / \mathrm{kg}\right)\left(18 \frac{\mathrm{kg}}{\text { year }}\right)\left(1.81 \frac{\mathrm{rea}}{\mu C i}\right) \\
& =7.5 \times 10^{-6} \mathrm{rem} / \text { year } \\
& =7.5 \times 10^{-3} \mathrm{mill} \text { iren/year. }
\end{aligned}
$$

The dose rates to other organs from the ingestion of $131_{\text {I }}$ in leafy veget.ables are also calculated from Eq. (B. 17):

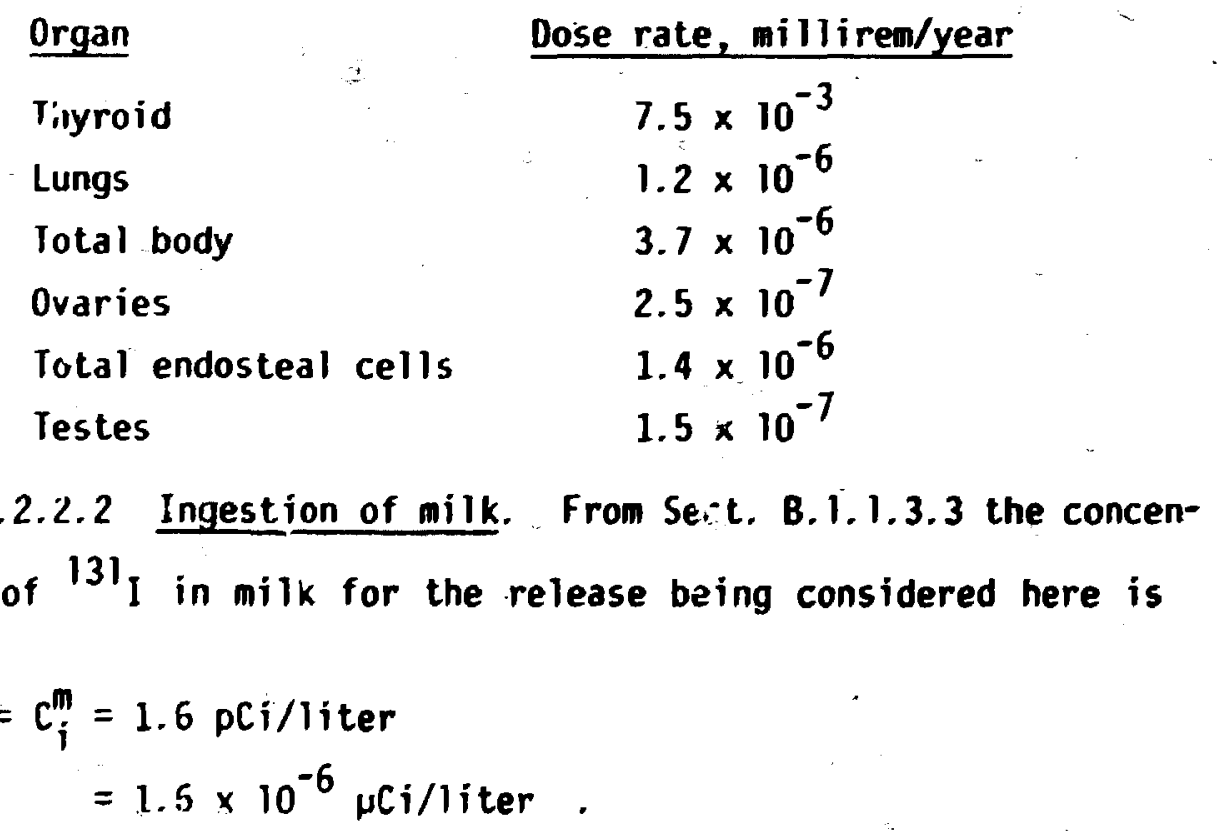


Once again assuming all of the milk a person consumes comes from the area surrounding the release being considered, Table 6.1 gives an annual average adult intake rate for wilk

$$
U_{i}^{f}=112 \text { liter/year. }
$$

The appropriate dose conversion factors may again be found in Table $? 1$. For $i={ }^{131} I$ and $j=$ thyroid, it is again found that

$$
0_{i j}^{f}=1.81 \mathrm{ren} / \mu \mathrm{Ci}
$$

Applying Eq. (B. 17), the dose rate to the thyroid is

$$
\begin{aligned}
R_{i j}^{f} & =\left(1.6 \times 10^{-6} \mu C i / 1\right)(112 \text { liter/year })(1.81 \mathrm{rem} / \mu C \mathrm{C}) \\
& =3.2 \times 10^{-4} \mathrm{rem} / \text { year } \\
& =3.2 \times 10^{-1} \text { millirem/;ear. }
\end{aligned}
$$

Similar calculations for $t: \geq$ slose rate to other organs due to the ingestion of $131^{\text {I }}$ in milk are included in the following:

\begin{tabular}{ll} 
Organ & Dose rate, millirem/year \\
\cline { 2 - 3 } Thyroid & $3.2 \times 10^{-1}$ \\
Lungs & $5.1 \times 10^{-5}$ \\
Total body & $1.6 \times 10^{-4}$ \\
Ovaries & $1.1 \times 10^{-5}$ \\
Total endosteal cells & $6.0 \times 10^{-5}$ \\
Testes & $6.2 \times 10^{-6}$
\end{tabular}

B.2.2.2.3 Ingestion of meat. The dose to various organs as a result of the ingestion of ${ }^{131} I$ in meat may also be found using Eq. (B.17) and the following input parameters:

$$
\begin{aligned}
C_{i} & =C_{i}^{\tilde{r}}=2.9 \times 10^{-1} \mathrm{pCi} / \mathrm{kg} \text { (Sect. B. 1.1.3.4), } \\
& =2.9 \times 10^{-7} \mu C_{i} / \mathrm{kg}
\end{aligned}
$$




$$
\begin{aligned}
u_{i}^{f} & =2 \text { kgíyear (Table 6. I). } \\
\mathbf{v}_{\mathbf{i} j}^{f} & =\text { villues for various organs found in Table } 7.1 \text {. }
\end{aligned}
$$

If we again assune that the person consunes only beef raised in the area influenced by the release under consideration, the dose rates that result are as follows:

\begin{tabular}{lc} 
Organ & Dose rate, rea/year \\
\hline Lungs & $2.6 \times 10^{-7}$ \\
Total body & $8.2 \times 10^{-9}$ \\
Ovaries & $5.7 \times 10^{-10}$ \\
Total endosteal cells & $3.1 \times 10^{-9}$ \\
Testes & $3.3 \times 10^{-10}$ \\
Thyroid & $1.7 \times 10^{-5}$
\end{tabular}

\section{B.2.2.2.4 Ingestion. of fish. Equation (B. 17) may also be used} to calculate the dose due to the ingestion of fish containing ${ }^{137} \mathrm{Cs}$ as calculated in Sect. B.1.2.2. From that section,

$$
\begin{aligned}
C_{i}=C F_{i} & =1.7 \times 10^{-9} \mathrm{Ci} / \mathrm{kg} \\
& =1.7 \times 10^{-3} \mu \mathrm{Ci} / \mathrm{kg} .
\end{aligned}
$$

Table 6.1 gives, for freshwater finfish,

$$
u_{i}^{f}=4.4 \mathrm{~kg} / \text { year. }
$$

The rose conversion factors for $i={ }^{137}$ Cs are also found in Table 7.1. For $\mathrm{j}=$ total body.

$$
D_{i j}^{f}=4.91 \times 10^{-2}
$$


Assuming all of the fish corsumed by this person contains $c_{i}$, the resulting annual dose rate to the total body is

$$
\begin{aligned}
R_{i j}^{f} & =\left(1.7 \times 10^{-3} \frac{\mu C i}{\mathrm{~kg}}\right)\left(4.4 \frac{\mathrm{kg}}{\text { year }}\right)\left(4.91 \times 10^{-2} \frac{\mathrm{rem}}{\mu C \mathrm{i}}\right) \\
& =3.7 \times 10^{-4} \mathrm{rea} / \text { year } \\
& =3.7 \times 10^{-1} \mathrm{millirem} / \text { year. }
\end{aligned}
$$

Siailar calculations give the additional results included below for the other organs listed in Table 7.1 :

Oryan

Total body

Lungs

Ovaries

Total endosteal cells

Testes
Dose rate, milli irem/year

$3.7 \times 10^{-1}$

$1.5 \times 10^{-1}$

$5.6 \times 10^{-1}$

$6.0 \times 10^{-1}$

$5.0 \times 10^{-1}$

\section{B.2.3 Iritium and Carbon-14 Dose Calculations}

B.2.3.1 Iritiun doses. Assime ${ }^{3} H$ is being released from an eisvated source under the meteorological and location conditions considered for the ${ }^{85} \mathrm{Kr}$ release in Sect. B.1.1.2. From this section,

$$
\frac{x}{Q}=1.0 \times 10^{-6} \mathrm{~s} / \mathrm{m}^{3} .
$$

If we assume for this ${ }^{3} H$ release that $Q=1 \times 10^{-6} \mathrm{Ci} / \mathrm{s}$, then the air concentration is

$$
\begin{aligned}
x & =1.0 \times 10^{-12} \mathrm{ci} / \mathrm{m}^{3} \\
& =1.0 \times 10^{-6} \mathrm{pCi} / \mathrm{cm}^{3} .
\end{aligned}
$$

The total ingestion dose from ${ }^{3} \mathrm{H}$ for food and water ran be calculated using Eq. (8.1), 


$$
D_{t}=C_{f} x+C_{w^{x}}
$$

Using the values of $C_{f}$ and $C_{w}$ found in Sect. 8.1.2. the ${ }^{3} H$ ingestion dose for the release considered here is

$$
\begin{aligned}
D_{t}= & \left(6.18 \frac{\text { rem-cm }}{\mathrm{pCi}-\text { year }}\right)\left(1.0 \times 10^{-6} \frac{\mathrm{pCi}}{\mathrm{cm}^{3}}\right) \\
& +\left(5.70 \frac{\text { rem-cm }}{\mathrm{pCi}-\text { year }}\right)\left(1.0 \times 10^{-6} \frac{\mathrm{pCi}}{\mathrm{cm}^{3}}\right) \\
= & 1.2 \times 10^{-5} \mathrm{rem} / \text { year } \\
= & 1.2 \times 10^{-2} \mathrm{millirem} / \text { year. }
\end{aligned}
$$

The dose due to the inholation and skin absorption of ${ }^{3} \mathrm{H}$ is found from Eq. (B.16). For the total endosteal cells,

$$
\begin{aligned}
x_{i}^{a} & =1.0 \times 10^{-6} \mu \mathrm{Ci} / \mathrm{m}^{3}, \\
e_{r} & =8.03 \times 10^{3} \mathrm{~m}^{3} / \text { year (Table 6.1), } \\
0_{i j}^{b r} & \left.=9.85 \times 10^{-5} \mathrm{rem} / \mu C i \text { (Table } 7.1\right),
\end{aligned}
$$

and

$$
\begin{aligned}
R_{i j}^{b r} & =\left(1.0 \times 10^{-6} \frac{\mu C i}{m^{3}}\right)\left(8.03 \times 10^{3} \frac{\mathrm{m}^{3}}{\text { year }}\right)\left(9.85 \times 10^{-5} \frac{\mathrm{rem}}{\mu C \mathrm{i}}\right) \\
& =7.9 \times 10^{-7} \mathrm{rem} / \text { year } \\
& =7.9 \times 10^{-4} \mathrm{millirem} / \text { year. }
\end{aligned}
$$

For all other organs listed in Table $7.1,0_{i j}^{b r}=1.25 \times 10^{-4}$ resulting in $R_{i j}^{b r}=1.0 \times 10^{-3}$ millirem/year.

B.2.3.2 Carbon-14 doses. Assume that ${ }^{14} \mathrm{CO}_{2}$ is released with the $3_{H}$ considered in sect. B.2.3.1. As a result, 


$$
\frac{x}{Q}=1.0 \times 10^{-6} \mathrm{~s} / \mathrm{m}^{3}
$$

for this release situation also. If $Q=5.0 \times 10^{-7} \mathrm{ci} / \mathrm{s}$,

$$
\begin{aligned}
x & =5.0 \times 10^{-13}{\mathrm{Ci} / \mathrm{m}^{3}}^{-7} \mathrm{pCi} / \mathrm{cm}^{3} \\
& =5.0 \times 10^{-7}
\end{aligned}
$$

According to Sect. 8.2 the primary dose to man from ${ }^{14} \mathrm{C}$ is via the ingestion pathway. This dose rate for various organs is equal to the product of the concentration of ${ }^{14} \mathrm{C}$ in air and the appropriate dose convérsion factor listed in Table 8.1 . : ihe resulting dose rates from the air concentration noted above are as follows:

\begin{tabular}{ll} 
Organ & Dose rate, millirem/year \\
\hline Whole body & $6.0 \times 10^{-1}$ \\
Red marrow & 1.0 \\
Lungs & $2.5 \times 10^{-1}$ \\
Endosteal cells & $9.0 \times 10^{-1}$ \\
Stomach wall & $3.8 \times 10^{-1}$ \\
Lower large & $4.6 \times 10^{-1}$ \\
intestine wall & $2.7 \times 10^{-1}$ \\
Thyroid & $3.6 \times 10^{-1}$ \\
Liver & $3.3 \times 10^{-1}$ \\
kidneys & $2.2 \times 10^{-1}$ \\
Testes & $2.2 \times 10^{-1}$ \\
Ovaries &
\end{tabular}




\section{REFERENCES}

1. Yan der Hoven, I. 1968. Deposition of particles and gases. pp. 202-8. IN Slade, D. (ed.), Meteorology and Atcmic Energy - 1968. USAEC TID-24190.

2. Miller, C. H., and F. O. Hoffman. A critique of methods for estimating plume depletion and deposition of airborne radionuclides. IN Proceedings of the 12th Annual Symposizm of the German-Swiss Fachoerband fur Strahlenschutz. Norderney, Federal Republic of Cermany, October 2-6, 1978.

3. U.S. Department of Health, Education, and Welfare, Public Health Service. 1979. Radiological Health Handbook. Publication No. 2016.

4. Hoffman, F. O., and C. F. Baes III (eds.). 1979. A Statistical Analysis of Selected Parameterg for Predicting Fo.d Chain Transport and Internal Dose of Radionuclides. ORNL/NUREG/TM-282.

5. U.S. Nuclear Regulatory Commission. 1977. Regulatory Guide 1.113. Estimating Aquatic Dispersion of Effluents from Accidental and Routine Reactor Releases for the Purpose of Implementing Appendix I.

6. Yeh, G. 1979. Personal communication.

7. Moore, R. E., C. F. Baes III, L. M. McDowell-Boyer, A. P. Watson, F. O. Hoffman, J. C. Pleasant, and C. H. Miller. 1979. AIRDosEPA: A Computerized Methodology for Estimating Environmental Concentrations and Dose to Man from Airborne Relecses of Radionuclides. ORNL-5532. 